\title{
Mykorrhizafunktion bei der Konkurrenz um Stickstoff in Kalkbuchenwäldern
}

\author{
Dissertation \\ zur Erlangung des Doktorgrades \\ der Fakultät für Forstwissenschaften und Waldökologie \\ der Georg-August-Universität Göttingen
}

\author{
vorgelegt von \\ Martin Leberecht \\ geboren in Hamburg
}

Göttingen, 2014 
1. Gutachterin: Prof. Dr. Andrea Polle

2. Gutachter: Prof. Dr. Stefan Scheu

Tag der mündlichen Prüfung: 31.03.2014 


\section{Inhaltsverzeichnis}

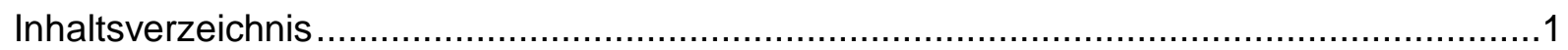

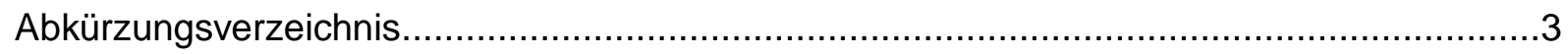

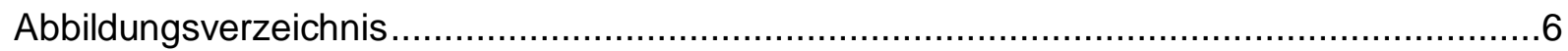

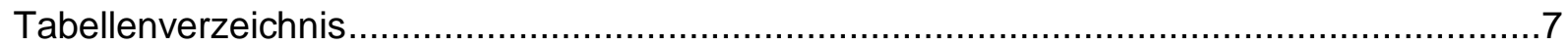

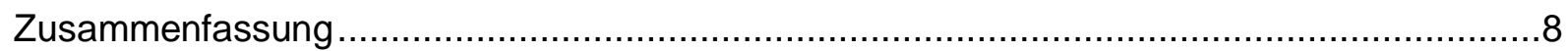

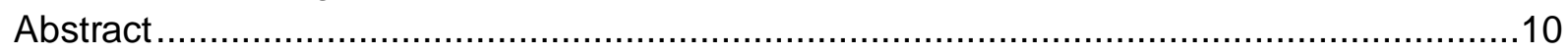

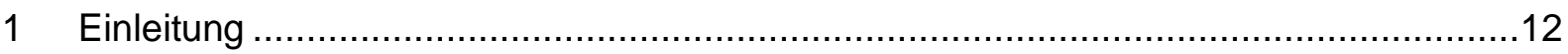

$1.1 \quad$ Mykorrhiza - eine Symbiose zwischen Pflanze und Pilz ...................................12

1.2 Die Anatomie und Morphologie von Ektomykorrhizen .....................................13

1.3 Die Rolle der Mykorrhiza im Stickstoffkreislauf der Waldökosysteme .....................15

1.4 Klimawandelbedingte Änderungen im Stickstoffkreislauf der Waldböden können sich auf die Verbreitung und Produktivität der Buchenwälder auswirken ................17

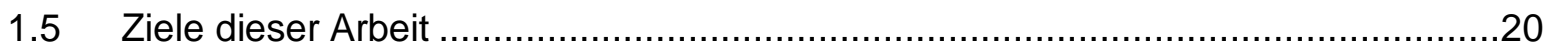

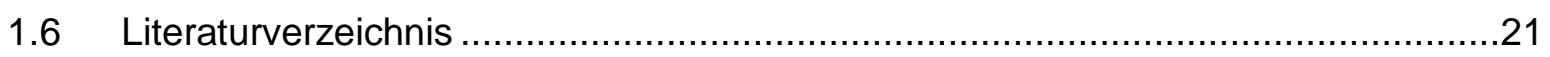

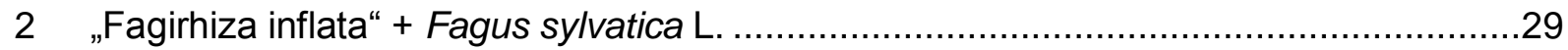

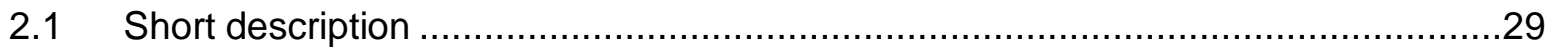

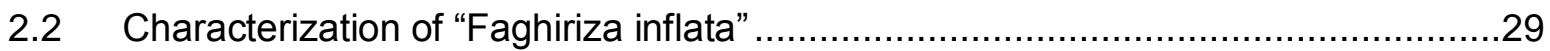

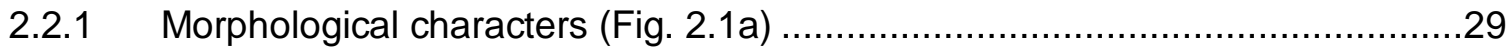

2.2.2 Anatomical characters of mantle in plan views (Fig. 2.2) ...............................29

2.2.3 Anatomical characters of emanating elements (Figs. 2.1b, c) ........................30

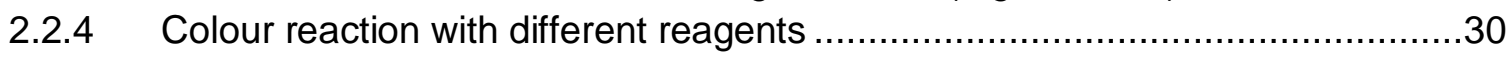

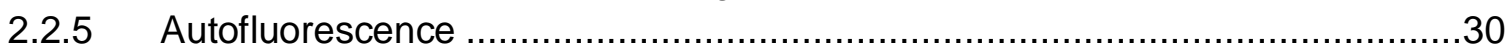

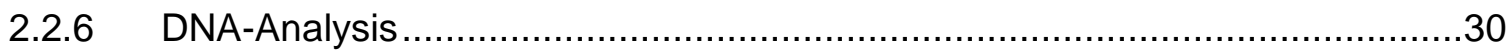

2.2.7 Reference specimen for Fagus sylvatica ectomycorrhiza .............................30

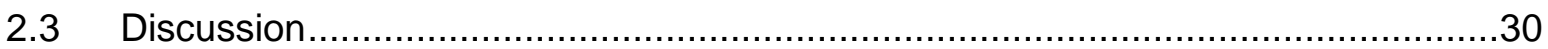

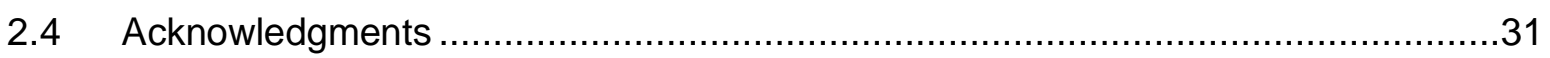

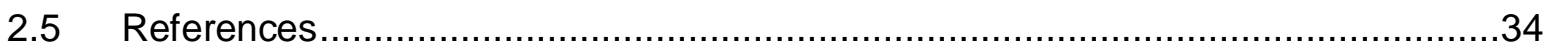

3 Dissecting the contributions of local ectomycorrhizal assemblages and microbial communities on nitrogen uptake of European beech (Fagus sylvatica) .........................35

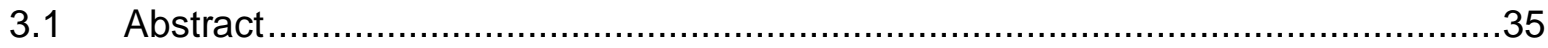

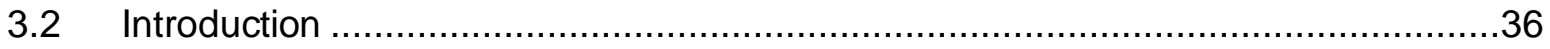

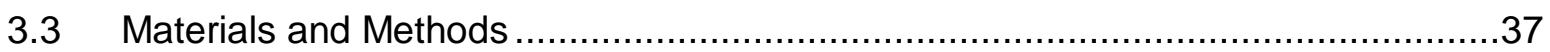

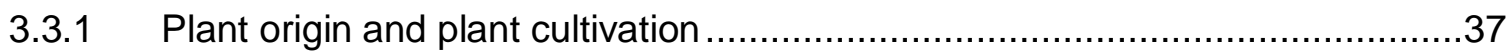

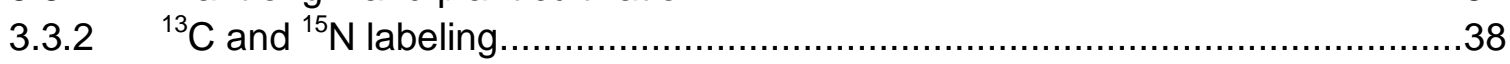

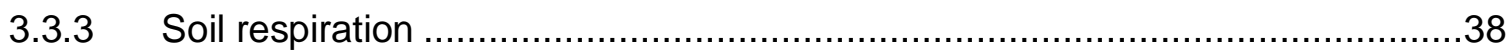

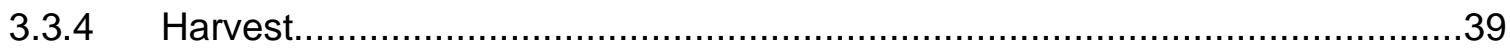

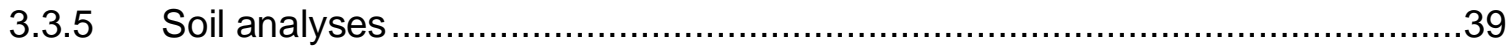

3.3.6 Identification of ectomycorrhizal fungi..................................................... 40

3.3.7 $\quad \mathrm{C}$ and $\mathrm{N}$ measurements and isotope analysis of plant tissues and mycorrhizal

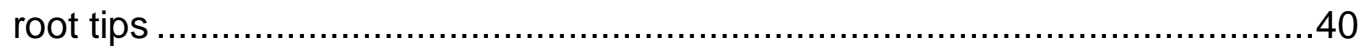

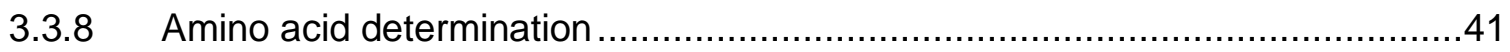

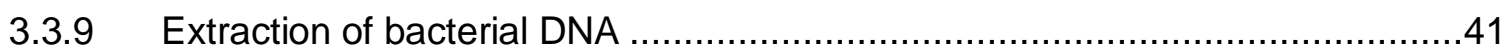


3.3.10 Total bacterial community structure

3.3.11 Abundance of mineralizers, nitrogen fixers, ammonia oxidizers and denitrifiers .

3.3.12 Data analysis $\quad 43$

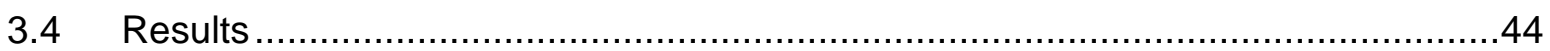

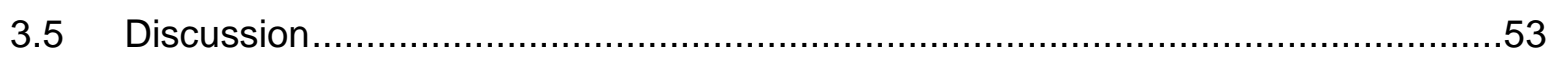

3.5.1 The difference in $\mathrm{N}$ acquisition by trees of different origin is not due to plant-

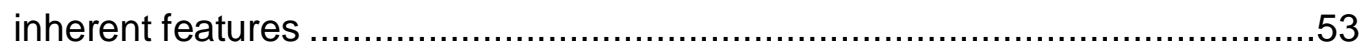

3.5.2 Mycorrhizal and bacterial contributions to beech $\mathrm{N}$ supply ...........................55

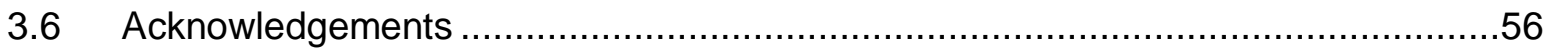

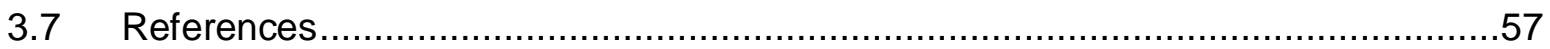

4 Climate change impairs nitrogen cycling in European beech forests ..........................65

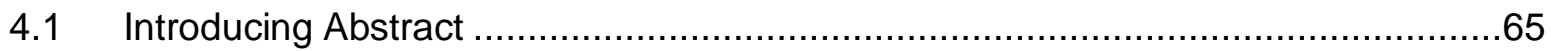

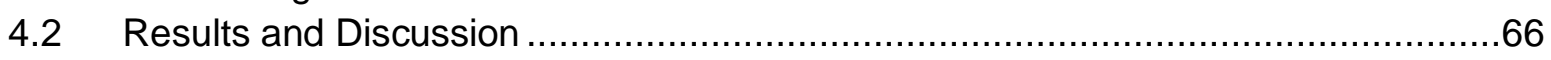

4.2.1 European beech forests on calcareous soil are endangered by climate change.

4.2.2 Climate change decelerates beech $\mathrm{N}$ nutrition as a consequence of impaired

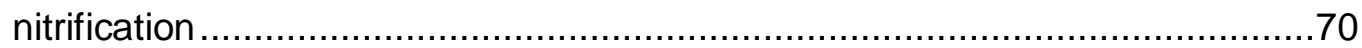

4.2.3 Implications for future forest management and ecosystem services ................78

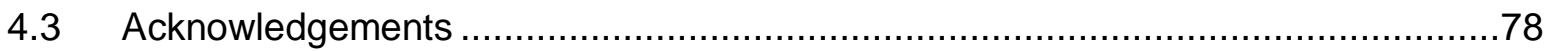

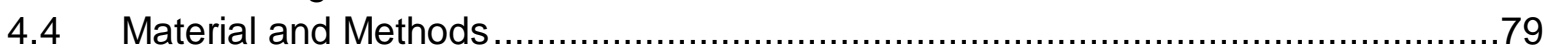

4.4.1 Maps intersection potential distribution of beech on calcareous sites ..............79

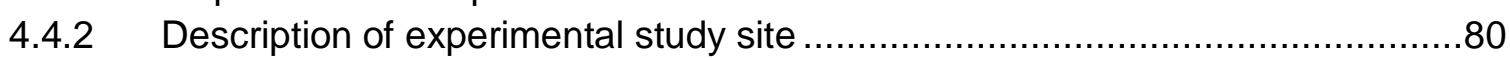

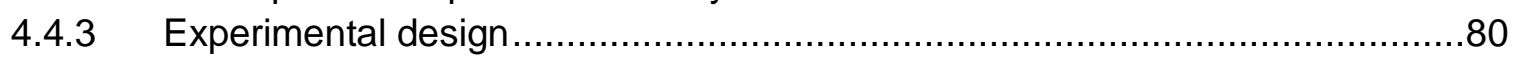

4.4.4 Transfer of intact beech-soil-microbe systems to simulate climate change ......80

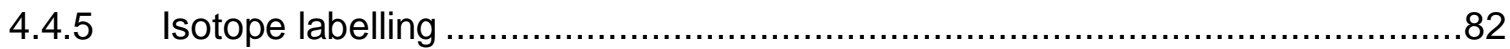

4.4.6 Beech-soil-mesocosm harvest and sample preparation ................................83

4.4.7 Total organic carbon (C), total $\mathrm{C}$ and $\mathrm{N}$ and $\delta^{15} \mathrm{~N}$ in bulk soil .........................84

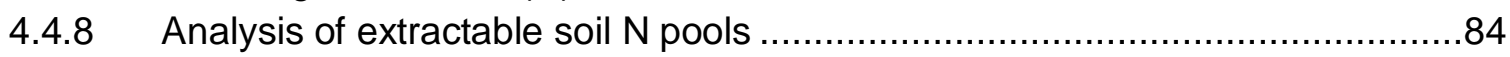

4.4.9 Analysis of ectomycorrhizal colonization and stable isotope analysis of

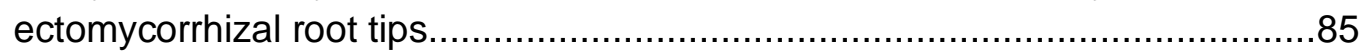

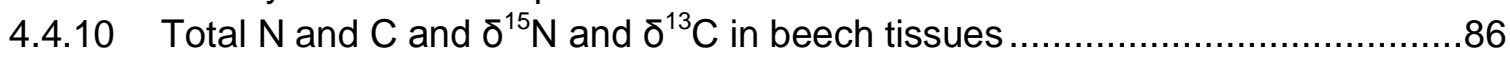

4.4.11 Metabolites: quantification total soluble protein, total amino acids and $\mathrm{NO}_{3}{ }^{-}$in

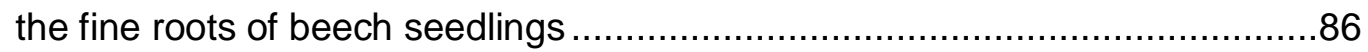

4.4.12 Nucleic acid extraction from bulk soil and rhizosphere .................................86

4.4.13 Quantitative real-time PCR assay to quantify key marker genes for $\mathrm{N}$ turnover

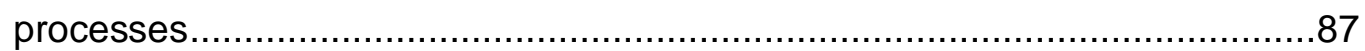

4.4.14 Calculation of $\mathrm{N}$ pools, isotope recovery and gross rates of $\mathrm{N}$ turnover ...........88

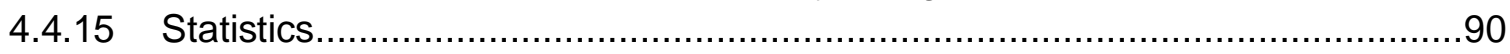

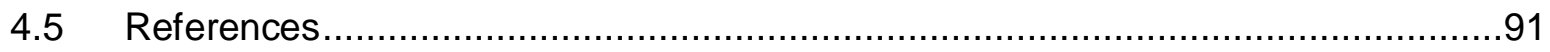

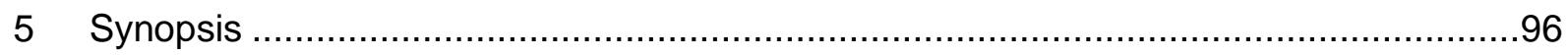

5.1 Morphologie und Anatomie als Basis für die Analysen von Ektomykorrhizagesellschaften und deren Funktionen. 
5.2 Ektomykorrhizapilze in der Stickstoffversorgungskette von Buchen.

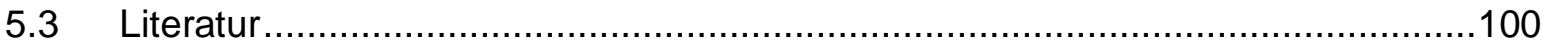

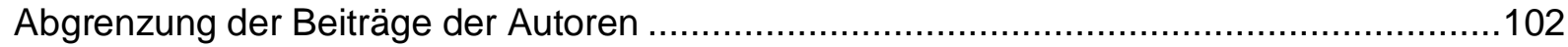

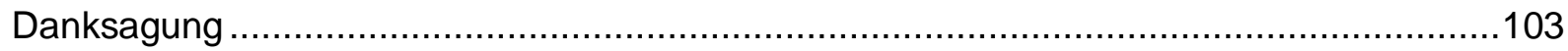

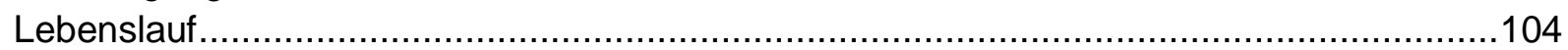

\section{Abkürzungsverzeichnis}

$\begin{array}{ll}\text { A } & \text { Ascomycota } \\ \text { a.s.l. } & \text { above see level } \\ \text { Ah } & \text { Oberbodenhorizont mit Humusanreicherung } \\ \text { amoA } & \text { Ammonia monooxigenase } \\ \text { ANOVA } & \text { Analysis of variance } \\ \text { AOA } & \text { Ammonia oxidizing archaea } \\ \text { AOB } & \text { Ammonia oxidizing bacteria } \\ \text { APE } & \text { Atom \% Excess } \\ \text { apr } & \text { Protease } \\ \text { Asco } & \text { Ascomycota } \\ \text { B } & \text { Basidiomycota } \\ \text { Basido } & \text { Basidiomycota } \\ \text { BSA } & \text { Bovine serum albumin } \\ \text { BV } & \text { Blind value } \\ \text { C } & \text { Kohlenstoff } \\ \text { C. } & \text { Cenococcum } \\ \text { CaSO } & \text { Calciumsulfat } \\ \text { chiA } & \text { Chitinase } \\ \text { CO }{ }_{2} & \text { Kohlenstoffdioxid } \\ \text { CuSO } & \text { Kupfer(II)sulfat } \\ \text { DEEMY } & \text { Determination of Ectomycorrhizae (Database) } \\ \text { DIN } & \text { Dissolves inorganic N } \\ \text { DMSO } & \text { Dimethyl sulfoxid } \\ \text { dNTP } & \text { Desoxynucleotide } \\ \text { DOC } & \text { Dissolved organic C } \\ \text { DON } & \text { Dissolved organic N } \\ \text { EDD } & \text { Ectomycorrhizae Descriptions Database } \\ \text { EDTA } & \text { Ethylenediaminetetraacetic acid } \\ \text { EM } & \text { Ectomycorrhiza } \\ \text { EMF } & \text { Ectomycorrhizal fungi } \\ \text { exc. } & \text { excavated } \\ \text { FEA } & \text { Formalin-ethyl acetate } \\ \text { FeCl }{ }_{3} & \text { Eisen(III)chlorid } \\ \text { FR } & \text { Fine roots } \\ \text { fw } & \text { Fresh weight } \\ \text { GLM } & \text { General linear model } \\ & \end{array}$




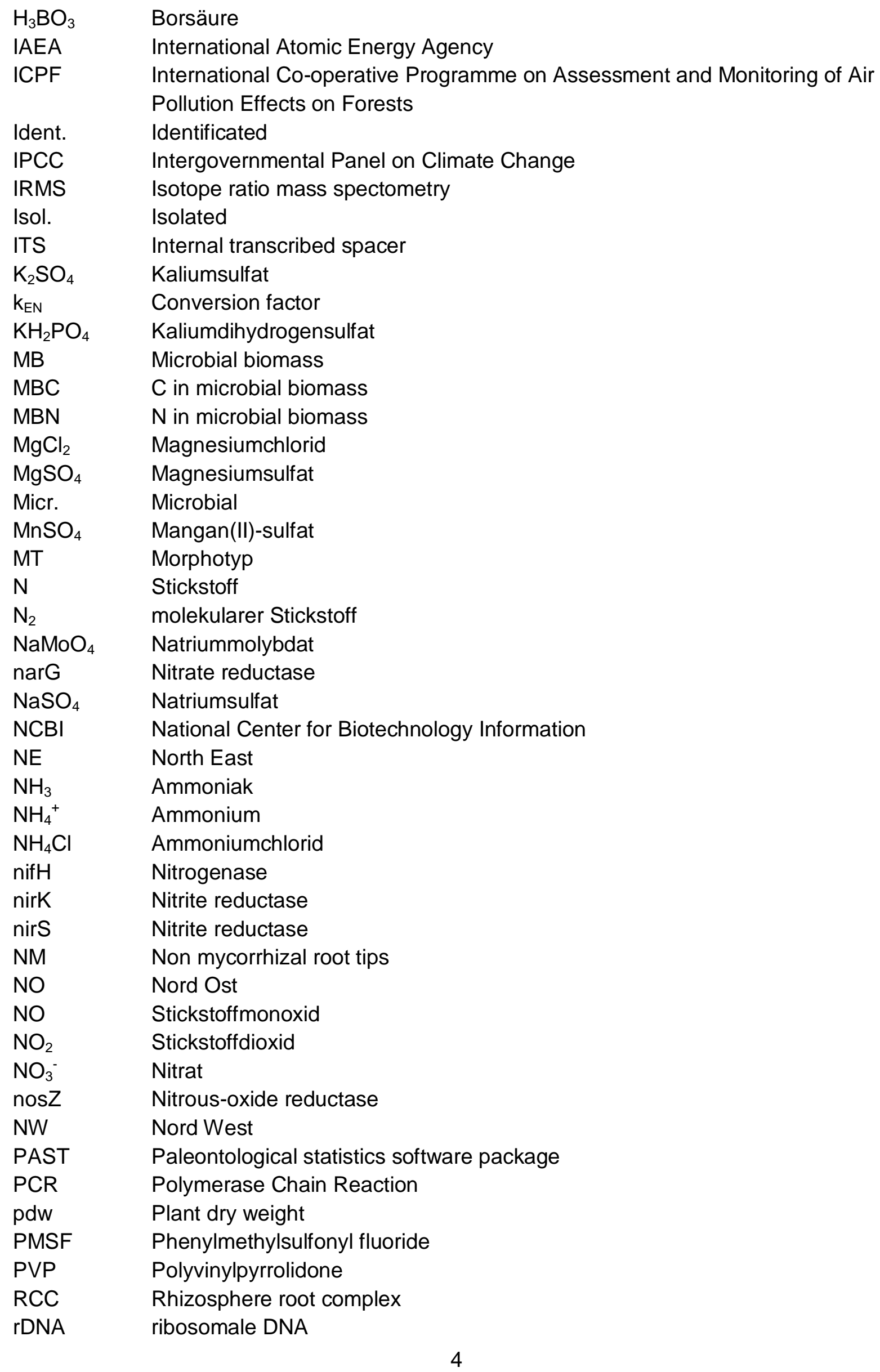




$\begin{array}{ll}\text { RFLP } & \text { Restriction Fragment Length Polymorphism } \\ \text { RS } & \text { Rhizosphere soil } \\ \text { RT-PCR } & \text { Real Time - Polymerase Chain Reaction } \\ \text { SDW } & \text { Soil dry weight } \\ \text { SE } & \text { Standard error } \\ \text { SFW } & \text { Soil fresh weight } \\ \text { SPADE } & \text { Species Prediction and Diversity Estimation } \\ \text { SRES A2 } & \text { Special Report on Emissions Scenario A2 } \\ & \text { (a very heterogeneous world with continuously increasing global population } \\ & \text { and regionally oriented economic growth) } \\ \text { SW } & \text { South West } \\ \text { SWC } & \text { Soil water content } \\ \text { t } & \text { Timepoint } \\ \text { TN } & \text { Total nitrogen } \\ \text { TNb } & \text { Total chemically bound N in soil extracts } \\ \text { TOC } & \text { Total organic C } \\ \text { TRF } & \text { Terminal restriction fragment } \\ \text { TRFLP } & \text { Terminal restriction fragment length polymorphism } \\ \text { UNITE } & \text { Unified system for the DNA based fungal species linked to the classification } \\ \text { UPLC } & \text { Ultra Performance Liquid Chromatography } \\ \text { USGS } & \text { United States Geological Survey } \\ \text { VPDB } & \text { Vienna Pee Dee Belemnite (IAEA Standard) } \\ \text { WHC } & \text { Water holding capacity } \\ \text { WRB } & \text { World Reference Base } \\ \text { ZnSO } & \text { Zinksulfat }\end{array}$




\section{Abbildungsverzeichnis}

Abbildung 1.1: $\quad$ Schematischer Aufbau einer Ektomykorrhiza mit pflanzlichen und pilzlichen Geweben 13

Abbildung 1.2: $\quad$ Der Stickstoffkreislauf in Waldökosystemen $\quad 17$

Figure 2.1: $\quad$ Morpologie von Fagirhiza inflata und Anatomie der Cystiden $\quad 32$

Figure 2.2: $\quad$ Anatomie der drei Mantelschichten von Fagirhiza inflata. 33

Figure 3.1: $\quad \delta^{13} \mathrm{C}$ signature of $\mathrm{CO}_{2}$ in static chamber headspace. 44

Figure 3.2: $\quad$ Differences in the abundance of ectomycorrhizal species on beech roots from the SW and the NE site 47

Figure 3.3: $\quad$ Saturation curves of rhizosphere soil, mycorhizosphere-root, associated bacteria and mycorrhizal communities 48

Figure 3.4: $\quad$ Morisita Horn Similarity Indices for pairwise comparisons of the microbial communities. 48

Figure 3.5: $\quad{ }^{15} \mathrm{~N}$ accumulation kinetics in soil $\mathrm{N}$ compounds, microbial biomass, ectomycorrhizas, and plant tissues. 52

Figure 3.6: $\quad$ Relative abundances of genes coding for important steps of the nitrogen cycle.

Figure 4.1: $\quad$ Modelled potential distribution of beech forests on calcareous soils in Europe.

$\begin{array}{lll}\text { Figure 4.2: } & \text { Experimental design } & 68\end{array}$

Figure 4.3: $\quad$ Soil temperature differences between beech-soil-mesocosms incubated at SW exposure and at NW exposure $\quad 69$

Figure 4.4: $\quad$ Dynamics of volumetric soil moisture in $5 \mathrm{~cm}$ depth in intact beech-soil-mesocosms of the control treatment and climate change treatment. $\quad 69$

Figure 4.5: Gravimetric soil moisture related to water holding capacity. $\quad 70$

Figure 4.6:

Figure 4.7:

Figure 4.8: Gross N turnover rates and N pool sizes in intact beech seedling-soil-mesocosms. Metabolites extracted from fine roots of beech seedlings in June 75

Figure 4.9: Ammonia oxidizing bacteria and nitrification rates 75 Long-term ${ }^{15} \mathrm{~N}$ recovery in beech seedlings $\quad 76$ 


\section{Tabellenverzeichnis}

Table 3.1: $\quad$ Primer sets and thermal profiles used for the absolute quantification of the respective genes

Table 3.2: $\quad$ Characteristics of the soil parameters 45

Table 3.3: Characteristics of young beech trees 45

Table 3.4: $\quad \delta^{13} \mathrm{C}$ signatures in plant tissues and ectomycorrhizas $\quad 46$

Table 3.5: Abundances and species identities of ectomycorrhizal fungi 49

Table 3.6: Diversity indices for ectomycorrhizas, mycorrhizosphere-root associated and rhizosphere soil bacteria $\quad 50$

Table 3.7: $\quad{ }^{15} \mathrm{~N}$ and $\mathrm{N}$ contents in young beech trees and soil microbial biomass and the ${ }^{15} \mathrm{~N}$ recovery rates of trees, microbes and total plant soil systems $\quad 50$

Table 4.1: $\quad{ }^{13} \mathrm{C}$ recovery in plant $\quad 72$

Table 4.2: $\quad{ }^{13} \mathrm{C}$ enrichment in excess of natural abundance in mycorrhizal root tips $\quad 72$

Table 4.3: $\quad$ Percentage of vital root tips colonized with mycorrhizal fungi $\quad 72$

Table 4.4: $\quad$ Total plant $N$ uptake $\quad 73$

Table 4.5: ANOVA analysis testing the factors exposure and time of gross rates of $\mathrm{N}$ turnover in the plant-soil-microbe system and corresponding $\mathrm{N}$ pools 74

Table 4.6: $\quad$ Abundance of microbes involved in selected steps of the $\mathrm{N}$ cycle $\quad 76$

Table 4.7: $\quad{ }^{15} \mathrm{~N}$ enrichment in excess of natural abundance in mycorrhizal root tips 77

Table 4.8: $\quad$ Aboveground and belowground dry plant biomass $\quad 77$

Table 4.9: $\quad$ Primer sets and thermal profiles used for the absolute quantification of the respective genes 


\section{Zusammenfassung}

Die Buche (Fagus sylvatica L.) ist sowohl in ökonomischer als auch in ökologischer Hinsicht in Mitteleuropa eine sehr wichtige Baumart. Häufig sind Buchenwälder auf Böden anzutreffen, auf denen Stickstoff das limitierende Nährelement ist. Auf solchen Böden konkurrieren deshalb Buchen, Ektomykorrhizapilze und Bodenbakterien um den verfügbaren Stickstoff. Der prognostizierte Klimawandel mit steigenden Temperaturen, Trockenperioden und Starkregenereignissen wird den Stickstoffkreislauf und die Konkurrenzverhältnisse beeinflussen, da sich zwei der wichtigsten Bodenparameter, Bodenfeuchte und Bodentemperatur, verändern werden. In diesen Parameter unterscheiden sich auch die beiden Versuchsflächen in Baden-Württemberg in der Nähe von Tuttlingen, die für die Versuche dieser Arbeit ausgewählt wurden. Die Flächen befinden sich gegenüberliegend in einem Tal und sind auf der einen Seite NO bez. NW exponiert und auf der anderen Seite SW exponiert. Der SW-Hang weist im Vergleich zu den nördlich exponierten Hängen eine erhöhte Bodentemperatur und eine verminderte Bodenfeuchte auf und kann damit als Modellstandort für das prognostizierte zukünftige Klima gelten. Wie die Buche mit den erwarteten klimatischen Änderungen umgehen wird, wird unter anderem auch von der Reaktion der Ektomykorrhizapilze abhängen. Diese spielen bei der Stickstoffaufnahme der Buchen eine entscheidende Rolle, da die Wurzelspitzen der Buche in natürlichen Ökosystemen praktisch vollständig mit Ektomykorrhizapilzen kolonisiert sind.

Um die komplex zusammengesetzten Mykorrhizagesellschaften an Buchen charakterisieren und in Bezug auf ihre Funktion analysieren zu können, sind Informationen über die Morphologie und Anatomie der einzelnen Pilzarten notwendig. Selbst in Mitteleuropa fehlen aber für einen Großteil der Ektomykorrhizen exakte wissenschaftliche Beschreibungen. Daher wurde exemplarisch ein mykorrhizaler Morphotyp, der auf den Tuttlinger Versuchsflächen häufig vorkommt, morphologisch und anatomisch beschrieben und gezeichnet. Wegen seiner dicht mit langen Cystiden besetzten Manteloberfläche wird er dem „Short distance“-Explorationstyp zugeordnet. Besonders auffällig sind die drei bis sechsfachen Verzweigungspunkten der Cystiden, die charakteristisch verdickt sind und denen die Mykorrhiza ihren provisorischen Namen „Fagirhiza inflata“ verdankt. Die aufgrund der anatomischen Merkmale und der dextrinoiden Reaktion von Mantel und Cystiden mit Melzers Reagenz angenommene Zugehörigkeit zur Gattung Sebacina wurde durch die ITSSequenzierung bestätigt.

Bisher war unklar, ob die Stickstoffversorgung von Buchen unter gegebenen Bedingungen von den Bodenmikroben, den Mykorrhizapilzen oder der Herkunft der Bäume abhängt. In einem Experiment sollte untersucht werden, ob und wie sich die unterschiedliche Artenzusammensetzung von Mykorrhizagesellschaften auf die Stickstoffakkumulation in den mykorrhizierten Wurzelspitzen und den Stickstofftransfer zu den Pflanzen auswirkt. Es wurden junge, genetisch ähnliche Buchen mit ihren assoziierten Mykorrhizagesellschaften aus Tuttlingen von einem NO-Hang und einem SW-Hang in einen homogenen Boden transferiert und unter gleichen klimatischen Bedingungen mit ${ }^{13} \mathrm{C}$ und ${ }^{15} \mathrm{~N}$ markiert. Die geringe mikrobielle Biomasse im Substrat führte dazu, dass die Konkurrenz um den Stickstoff mit Bakterien stark vermindert wurde. Die nicht mykorrhizierten Wurzelspitzen der NO- und SW-Buchen akkumulierten unter diesen Bedingungen das ${ }^{15} \mathrm{~N}$ gleich stark. Im Gegenteil dazu akkumulierten die mykorrhizierten Wurzelspitzen der NW-Buchen das ${ }^{15} \mathrm{~N}$ 
stark verzögert im Vergleich zu den mykorrhizierten Wurzelspitzen der SW-Buchen. Korrespondierend dazu dauerte bei den NO-Buchen der Transfer des ${ }^{15} \mathrm{~N}$ zu den Feinwurzeln und Blättern länger und erfolgte in niedrigeren Raten als bei den SW-Buchen. Daraus folgt, dass die Mykorrhizagesellschaften den N-Transport zur Pflanze kontrollierten. Außerdem zeigen diese Ergebnisse, dass die Mykorrhizapilze, die sich an trockene und warme Bedingungen angepasst haben, die Leistungsfähigkeit von den an moderate Bedingungen angepassten Mykorrhizapilzen in Bezug auf die Akkumulation von Stickstoff sogar übertreffen, wenn die umweltbedingten Einschränkungen wegfallen. Die Ergebnisse legen nahe, dass die Zusammensetzung der Mykorrhizagesellschaften entscheidend für die Zukunftsfähigkeit der Buchenwälder ist.

Um die Auswirkungen des prognostizierten Klimawandels (erhöhte Temperatur und niedrigere Bodenfeuchte) auf die Stickstoffversorgung von Buchen abschätzen zu können, wurde Buchennaturverjüngung mit umgebendem Boden (Mesokosmen) in Tuttlingen von dem NW-Hang auf den gegenüberliegenden SW-Hang ("Klimawandel" Behandlung) oder von dem NW auf den NW Hang (Kontrolle) transferiert. Die Buchen wurden für ein Jahr unter diesen Bedingungen kultiviert. In der nachfolgenden Vegetationsperiode wurde nach Injizieren von ${ }^{15} \mathrm{~N}$ markierten Stickstoffformen (Glutamin, Ammonium, Nitrat) in den Boden an mehreren Zeitpunkten geerntet. Anhand der ${ }^{15} \mathrm{~N}$-Aufnahmeraten stellte sich Nitrat als die dominierende Stickstoffquelle für die Buchen heraus. Die klimatischen Bedingungen auf der SW-Seite führten zu einem Einbruch bei der Nitratbereitstellung durch die Bodenbakterien und damit zu Nitratmangel und nachfolgend zu einer Reduktion der Biomasse der Buchennaturverjüngung. In den mykorrhizierten Wurzelspitzen hingegen zeigte sich durchgängig, dass ${ }^{15} \mathrm{~N}$ aus Ammonium am stärksten akkumuliert wurde, gefolgt von Nitrat und Glutamin. In den meisten Fällen wurde auf der SW-Seite signifikant oder tendenziell weniger ${ }^{15} \mathrm{~N}$ akkumuliert als auf der NW-Seite. Intaktes Glutamin wurde weder in den mykorrhizierten Wurzelspitzen noch in den Buchen festgestellt, was auf eine sehr geringe Bedeutung von organischen Stickstoffformen für die Stickstoffversorgung der Buchen schließen lässt. Die Ergebnisse lassen befürchten, dass es in Zukunft große Probleme bei der Stickstoffversorgung der Buche geben wird. Vermutlich sind diese Restriktionen in der Stickstoffversorgung eine der Ursache für die prognostizierte erhebliche Reduktion der Kalkbuchenwälder bis zum Ende des 21. Jahrhunderts. 


\section{Abstract}

Beech (Fagus sylvatica L.) is a very important tree species in Central Europe due to its economical value and ecological services. Beech forests are often growing on soils, where nitrogen is the growth limiting factor. Under these conditions beech trees, ectomycorrhizal fungi and soil bacteria are competing for the bioavailable nitrogen in the soil. The predicted climate change will influence the nitrogen cycle and competition for nitrogen, because the two main soil parameters, soil humidity and soil moisture, will change. These two parameters are different at the two experimental sites near Tuttlingen (SW Germany). The two sites are divided by a narrow valley and are on the one hand side NE or respectively NW exposed and on the other side SW exposed. Compared to the northern exposed slopes, the SW slope shows higher soil temperature and lower soil humidity. Therefore the SW-slope can be taken as a model site for future climate conditions. The reactions of beech forests to climate change are, among other factors, dependent on the reaction of ectomycorrhizal fungal to climate change. These fungi are very important for nitrogen nutrition of beech, because nearly all root tips are colonized by these fungi.

For analyzing complex assembled mycorrhizal communities and characterizing their functions, information about morphology and anatomy of single species are necessary. But even in Central Europe scientific descriptions for most of the ectomycorrhizal fungi are lacking. Because of this lacking knowledge, a common mycorrhizal morphotype of the experimental sites in Tuttlingen was morphological and anatomical described and drawn. The new morphotyp is densely covered with cystidia and is therefore determined as a "Short distance"-Exploration type. Characteristic are the inflated three to six fold polytomies of the cystidia. They lead to the temporary name "Fagirhiza inflata". Anatomical features and dextrinoide reaction with Melzer's reagent suggested this fungus belonging to the order Sebacina, which was confirmed via ITS sequencing.

Until now it was not clear, if nitrogen nutrition of beech trees is dependent on soil bacteria, mycorrhizal fungi or origin of the trees. In an experiment the influence of different mycorrhizal assemblages on nitrogen accumulation in root tips and subsequent transfer to plants was examined. Young, genetically similar beech trees including associated mycorrhizal assemblages from Tuttlingen NE and SW slope were transferred to a homogenous soil. The trees were cultivated under equal climate conditions and labeled with ${ }^{13} \mathrm{C}$ and ${ }^{15} \mathrm{~N}$ before harvest. Because of very low microbial biomass in the soil, competitive strength of microbial biomass was strongly reduced. ${ }^{15} \mathrm{~N}$ accumulation in non mycorrhizal root tips from NE and SW beeches was similar under these conditions. In contrast to this result, mycorrhizal root tips of SW trees accumulated more ${ }^{15} \mathrm{~N}$ than mycorrhizal root tips from NE beech trees.

Corresponding to this ${ }^{15} \mathrm{~N}$ transfer to fine roots and leaves was faster in SW trees compared to NE trees. This result shows that mycorrhizal fungi are controlling the $\mathrm{N}$ transfer to the plant. Furthermore these results show, that drought and warm conditions adapted mycorrhizal fungi are more efficient under mild conditions than the mycorrhizal fungi adapted to the mild conditions, if climatically constraints do not exist. These findings suggest that community structure of ectomycorrhizal fungi is crucial for sustainability of beech forests.

To estimate impacts of the predicted climate change (higher temperature and lower soil moisture) on nitrogen nutrition of beech trees an experiment under field conditions was 
conducted. Beech soil systems (mesocosms) were transferred from a NW to a SW slope (climate change treatment) and from a NW to a NW slope (control). The beech trees were cultivated under site specific condition for one year. In the following vegetation period beech trees were harvested after injections with ${ }^{15} \mathrm{~N}$ labelled nitrogen forms (glutamine, ammonium and nitrate) at several time points. Climatic constraints lead to a strong reduction of soil bacteria which can provide nitrate. As a consequence beech trees showed a reduction in biomass because nitrate was the dominant nitrogen source for beech nutrition, indicated by highest ${ }^{15} \mathrm{~N}$ accumulation of all three nitrogen forms. In contrast to beech trees mycorrhizal root tips showed highest ${ }^{15} \mathrm{~N}$ accumulation derived from ammonium, followed by nitrate and glutamine. In most cases, accumulation in mycorrhizal root tips on the SW slope was significant or by trend lower than on the NW slope. Intact glutamine was found neither in mycorrhizal root tips nor in beech trees. This means organic nitrogen is not important for beech nutrition.

In conclusion, these results show, that in future serious problems in nitrogen nutrition of beech trees can occur. A model, which predicts a strong reduction of beech forest in Central Europe at the end of the 21th century, takes into account the change of soil parameters shown by the experiments described here. 


\section{Einleitung}

\subsection{Mykorrhiza - eine Symbiose zwischen Pflanze und Pilz}

Unter einer Mykorrhiza versteht man eine im Bereich der Feinwurzeln angesiedelte, meist mutualistische Beziehung zwischen einer Gefäßpflanze und einem Pilz. Der Pilz hat durch sein oft weit verzweigtes, aus dünnen Hyphen bestehendes, extramatrikales Mycel Zugriff auf Nährstoff- und Wasserressourcen, die für die Pflanze mit ihren im Vergleich zu den Hyphen sehr voluminösen Feinwurzeln nicht erreichbar sind. Im Austausch mit photosynthetisch gewonnenen Kohlenhydrate gibt der Pilz Nährstoffe wie Stickstoff oder Phosphat an die Pflanze weiter (Smith and Read, 2010).

Die evolutionäre Entwicklung dieser Symbiose ist eng an die Entwicklung der Landpflanzen geknüpft (Brundrett, 2002). Bereits im Devon vor ca. 400 Mio. Jahren traten zusammen mit den ersten Bryophyten arbuskuläre Mykorrhizen auf (Taylor et al., 1995). Im Laufe der Zeit haben sich verschiedene Typen von Mykorrhizen entwickelt, die sich bezüglich ihrer Morphologie und ihrer Wirtspflanzen unterscheiden. Die zur heutigen Zeit in den temperaten und borealen Wäldern dominierende Form der Ektomykorrhiza trat vermutlich vor ca. 180 Mio. Jahren das erste Mal auf (Berbee and Taylor, 1993). Die ältesten fossilen Nachweise von Ektomykorrhizen an einer Laubbaumart stammen aus dem Unteren Eozän und sind ca. 52 Millionen Jahre alt (Beimforde et al., 2011).

Theodor Hartig beschrieb 1840 als Erster die Strukturen des äußeren Hyphenmantels und der interzellulären Hyphen, ohne jedoch zu erkennen, dass es sich um Pilze handelt (Trappe, 2005). Nach inm ist das „Hartigsche Netz" benannt, das als Austauschorgan zwischen Pilz und Pflanze dient. Nachdem Bruchmann (1874) erkannt hatte, dass diese Strukturen pilzlichen Ursprungs sind, prägte Albert Bernhard Frank (1885) den Begriff Mykorrhiza. Er fertigte detaillierte Zeichnungen an und stellte die wegweisende Hypothese auf, dass es sich um eine symbiotische Beziehung handelt und dass der Pilz zur Ernährung der Pflanze beiträgt. Es dauerte jedoch über 50 Jahre, bis seine Hypothese bestätigt werden konnte (Trappe, 2005).

Heutige Schätzungen gehen von 7000 - 10000 Pilzarten aus, die in der Lage sind, Ektomykorrhizen auszubilden (Rinaldi, 2008; Taylor and Alexander, 2005). Der mit $95 \%$ größte Anteil gehört zum Phylum der Basidiomyceten. 4,8 \% gehören zum Phylum der Ascomyceten und die verbleibenden 0,2 \% zum Phylum der Zygomyceten (Molina et al., 1992). Ca. 8000 verholzende Pflanzen kommen als Partner in Frage (Meyer, 1973). Die Buche, der durch ihre vorherrschende Stellung in der potentiellen natürlichen Vegetation Mitteleuropas (Ellenberg and Leuschner, 1996) eine besondere Bedeutung zukommt, ist zu nahezu $100 \%$ mykorrhiziert und wird innerhalb eines Bestandes von ca. 60 - 90 Pilzarten besiedelt (Buée et al., 2005; Pena et al., 2010). 


\subsection{Die Anatomie und Morphologie von Ektomykorrhizen}

Ektomykorrhizen lassen sich in die anatomisch sehr unterschiedlichen Organe Hartigsches Netz, Mantel und extramatrikales Mycel einteilen (abziehende Hyphen und Rhizomorphen) (Abbildung 1.1). Das Hartigsche Netz ist der Bereich, über den der Stoffaustausch zwischen den beiden Organismen stattfindet. Bei Angiospermen beschränkt sich der besiedelte Bereich in der Regel auf die Epidermis (Godbout and Fortin, 1983). Es gibt aber Mykorrhizapilze z.B. an der Buche, die auch die Cortex- und Endodermiszellen besiedeln (Clowes, 1951). Bei Gymnospermen werden in der Regel die Cortexzellen und teilweise auch die Endodermiszellen umwachsen (Smith and Read, 2010). Überwiegend findet radiales und nur sehr eingeschränkt longitudinales Hyphenwachstum statt (Kottke and Oberwinkler, 1986). Die Hyphen verzweigen sich im Interzellularraum, anders als im Mantel und im extramatrikalen Mycel, extrem häufig (Mangin, 1910) und liegen dicht gepackt (Smith and Read, 2010). Dadurch entsteht eine große Kontaktfläche, über die der Stoffaustausch stattfinden kann. Sowohl Basidiomyceten als auch Ascomyceten bilden, auch an verschiedenen Wirtspflanzen, sehr ähnliche Strukturen (Blasius et al., 1986).

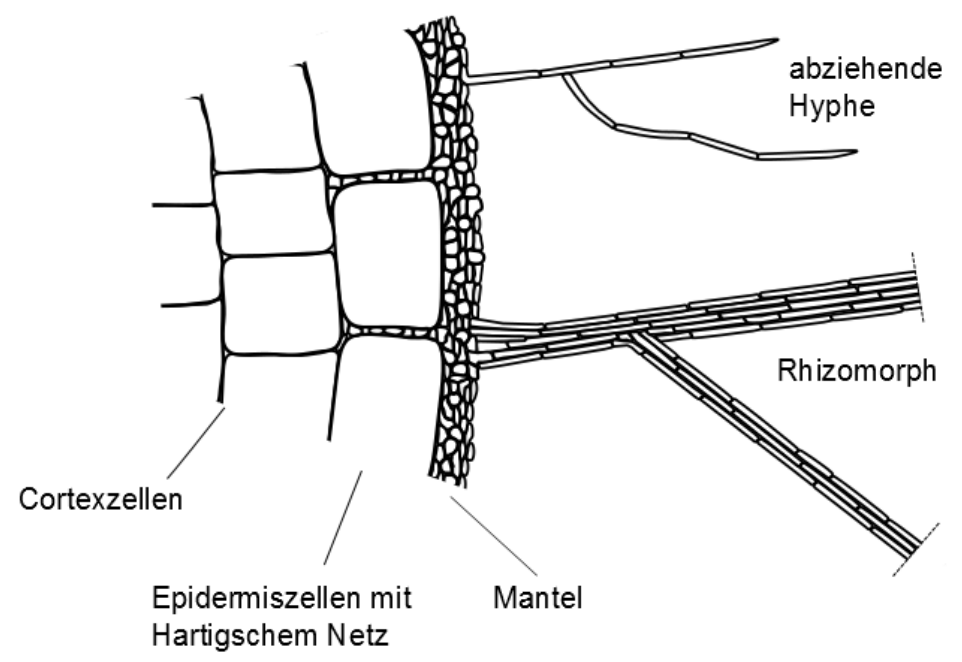

Abbildung 1.1: Schematischer Aufbau einer Ektomykorrhiza mit pflanzlichen (Cortex- und Epidermiszellen) und pilzlichen Geweben (Hartigsches Netz, Mantel, abziehender Hyphe und Rhizomorph)

Der Mantel umhült die mykorrhizierte Wurzelspitze und ist das Bindeglied zwischen dem extramatrikalen Mycel und dem Hartischen Netz. Je nach Mächtigkeit und Struktur liegt der Gewichtsanteil des Mantels an der mykorrhizierten Wurzelspitze zwischen $20 \%$ (Vogt et al., 1982, 1991) und $40 \%$ (Harley and McCready, 1952). Man unterscheidet zwischen plectenchymatischen und pseudoparenchymatischen Manteltypen. Ein pseudoparenchymatischer Mantel besteht aus isodiametrischen bis unregelmäßig puzzleartigen Zellen, die kaum noch an die fadenartigen Strukturen von Hyphen erinnern. In einem plectenchymatischen Mantel sind die fadenartigen Hyphen als solche noch erkennbar. Es können größere Interhyphalräume auftreten. Teilweise sind die Zwischenräume auch mit 
einer Matrix gefüllt (Godbout and Fortin, 1983; Kottke and Oberwinkler, 1986). Ein Mykorrhizamantel ist oft in mehrere Schichten gegliedert, die unterschiedliche anatomische Merkmale besitzen (Agerer, 1987-2006). Plectenchymatische und pseudoparenchymatische Schichten können sich dabei abwechseln. Häufig kommen auch spezielle Strukturen wie Setae (sehr spitze, dickwandige und häufig stark melanisierte Zellen), Cystiden (teils mit giftigen Substanzen gefüllte, dünnwandige Zellen), Milchröhren und pigmentierte Hyphen vor (Agerer, 1986; Peyronel, 1960; Taylor and Alexander, 2005). Mantelstrukturen sind zum Teil spezifisch und können daher sehr gut zur Bestimmung von Mykorrhizen herangezogen werden (Agerer, 1995). Die Hyphenoberflächen werden auch von Bakterien besiedelt, die die Funktion der Symbiose unterstützen können (Frey-Klett et al., 2007).

Die Funktion des Mantels ist primär die Speicherung von Nährstoffen wie Phosphor- und Stickstoffverbindungen, z.B. für die Fruchtkörperproduktion, bei der in einem kurzen Zeitfenster große Mengen an Nährstoffen benötigt werden (Taylor and Alexander, 2005). Die $\mathrm{P}$ - und N-Konzentrationen sind vier- bis fünffach höher als im Pflanzengewebe (Vogt et al., 1981) und scheinen auch an den Nährstoffbedarf der Wirtspflanze gekoppelt zu sein (Genet et al., 2000; Lussenhop and Fogel, 1999). Um die Speicherfunktionen erfüllen zu können, müssen die Mäntel relativ langlebig sein. Die Lebensdauer der mykorrhizierten Spitzen reicht von einigen Monaten bis hin zu 2,5 Jahren (Withington et al., 2006). Der Mantel wird z.B. mechanisch durch Setae und chemisch durch Cystiden vor Fraß geschützt (Taylor and Alexander, 2005). Zusätzlich können die Hyphen des Mantels und auch des extramatrikalen Myzels mit Kristallen aus z.B. Calciumoxalat besetzt sein (Brand, 1991).

Vom Mantel ziehen sehr häufig Hyphen und Rhizomorphen (aus mehreren Hyphen zusammengesetzte Mycelstränge) in den Boden ab und bilden gemeinsam das extramatrikale Mycel. Dieses Pilzmycel wirkt stark oberflächenvergrößernd und erschließt Bodenregionen, die nicht im direkten Kontakt zum Mantel stehen. Neben den einzelnen Hyphen werden 6 verschiedene Rhizomorphentypen unterschieden (Agerer, 1991, 1995). Die Formen reichen von lose verwobenen Hyphen bis hin zu kompakten, differenzierten, im Inneren mit großen, gefäßartig aufgebauten Hyphen ohne Septen, die einen Transport von Nährstoffen und Wasser über große Distanzen gewährleisten. Für Stabilität sorgen verschiedene Typen von Anastomosen (Verbindung zwischen zwei Hyphen), die offen oder septiert sein können, gelatinöse Zellwände und zurück- und vorwärtsgerichtete Verzweigungen (Agerer 1992). Während die Transportorgane überwiegend hydrophob sind, sind die Spitzen der Hyphen, oder die aufgefächerten Enden der Rhizomorphen meist hydrophil, um Nährstoffe und Wasser besser aufnehmen zu können (Unestam and Sun, 1995). Da die Strukturen eine Vielzahl an Merkmalen bieten, die teilweise charakteristisch für Gattungen oder Arten sind, können Rhizomorphen und abziehende Hyphen ebenfalls gut zur Bestimmung von Ektomykorrhizen verwendet werden (Agerer, 1987-2006).

Eng verknüpft mit den Formen des extramatriaklen Mycels ist das Konzept der Explorationstypen (Agerer, 2001). Je nach Ausprägung der Strukturen werden Bodenvolumina in der Nähe oder in weiterer Entfernung von der Wurzelspitze erschlossen und unterschiedliche ökologische Nischen besetzt. Der Mantel von Ektomykorrhizen des „contact“-Typs, z.B. Russula sp. und Lactarius sp., ist glatt und besitzt nur sehr vereinzelt abziehende Hyphen (Agerer, 2006). Die Nährstoffaufnahme erfolgt über die Manteloberfläche (Harley and Smith, 1983). Ektomykorrhizen vom Typ „short distance“ haben eine große Anzahl an Hyphen mit einer Länge von bis zu ca. 0,5 cm, die das nahe 
Umfeld der Wurzelspitze ausbeuten können. Ein prominentes Beispiel ist Cenococcum geophilum (Agerer, 2001). „Medium distance“ Typen sind durch relativ undifferenzierte Rhizomorphen mit einer Reichweite im Zentimeterbereich charakterisiert. Es werden die Untertypen „fringe“ mit fächerartig vom Mantel abziehende Hyphen und vielfach verzweigten, undifferenzierten Rhizmorphen, „mat“ mit großflächigem, mattenartigem Myzel und „smooth“ mit glatten Mantel und meist undifferenzierten Rhizomorphen unterschieden. „Long distance“ Typen bilden differenzierte Rhizomorphen, die Wasser und Nährstoffe über weite Strecken transportieren können. Bei Pisolithus tinctorius wurden zum Beispiel $42 \mathrm{~cm}$ Rhizomorphenlänge gemessen (Schramm, 1966). Pilze der Gattungen Boletus, Paxillus und Suillus sind typische Vertreter dieses Typs (Agerer, 2006). Es kommt also für die Nährstoffversorgung des Wirtes nicht nur auf die Abundanz eines Morphotypes an (Thomson et al., 1994), sondern auch auf die Menge und Ausprägung des extramatrikalen Systems (Kammerbauer et al., 1989; Rousseau et al., 1992). Zusätzlich zur Exploration ist das extramatrikale Myzel auch für die Besiedelung von unmykorrhizierten Wurzelspitzen verantwortlich (Brundrett, 1991; Read, 1992).

\subsection{Die Rolle der Mykorrhiza im Stickstoffkreislauf der Waldökosysteme}

Waldökosysteme sind häufig durch Stickstoffarmut geprägt, mit der Folge, dass das Wachstum der Bäume stickstofflimitiert ist (Chapman et al., 2006; Lovett et al., 2004; Rennenberg et al., 2009). Wegen der geringen N-Zufuhr sind diese Ökosysteme auf ein effizientes Recycling und gleichzeitig auf geringe N-Verluste angewiesen (Schimel and Bennett, 2004). Die grundlegenden Prozesse des Stickstoffkreislaufes sind in Abbildung 1.2 dargestellt.

Die Zufuhr von Stickstoff in den Kreislauf erfolgt entweder über atmosphärische Deposition oder über die Fixierung von atmosphärischem Stickstoff durch Mikroorganismen (Rennenberg et al., 2009). Die Deposition ist anthropogen beeinflusst und kann in stark belasteten Gebieten bis zu 60 kg N ha-1 Jahr-1 (Tietema and Beier, 1995). Sie erfolgt in Form von $\mathrm{NO}_{2}, \mathrm{NO}, \mathrm{NO}_{3}{ }^{-}, \mathrm{NH}_{3}$ und $\mathrm{NH}_{4}{ }^{+}$(Rennenberg and Gessler, 1999). Im Vergleich dazu fällt die $\mathrm{N}_{2}$-Fixierung in den im Rahmen dieser Dissertation betrachteten temperaten Wäldern Mitteleuropas mit weniger als $3 \mathrm{~kg} \mathrm{~N} \mathrm{ha}^{-1} \mathrm{Jahr}^{-1}$ sehr gering aus (Cleveland et al., 1999). Sterben die N-fixierenden Mikroorganismen ab, werden deren komplexe organische Verbindungen depolymerisiert und stehen danach als monomere Verbindung den Pilzen, Pflanzen oder ammonifizierenden Mikroorganismen zur Verfügung (Rennenberg et al., 2009). Depolymerisation ist auch der erste Schritt beim Abbau abgestorbener pflanzlicher Biomasse, d.h. insbesondere von Blättern und Feinwurzeln. Insbesondere saprotrophisch lebende Pilze sind durch eine geeignete Ausstattung an extrazellulären Enzymen in der Lage, komplexe organische Stickstoffquellen zu erschließen (Bending and Read, 1996a, 1996b; Dighton, 2007). Nach der Depolymerisation können sowohl Mikroorganismen und Pflanzen auf die organischen Verbindungen zugreifen und stehen somit in Konkurrenz zueinander (Rennenberg et al., 2009). Teilweise können auch Mykorrhizapilze die organischen Stickstoffquellen abbauen und damit die Ammonifizierung und Nitrifizierung durch andere Mikroben umgehen (Cullings and Courty, 2009; Read and Perez-Moreno, 2003). Es wurde gezeigt, dass Pflanzen sowohl ohne Mykorrhiza (Abuzinadah and Read, 1986; Sangwanit, 1986) als auch mykorrhiziert unter natürlichen Bedingungen organische 
Stickstoffverbindungen aufnehmen können (Dannenmann et al., 2009; Finzi and Berthrong, 2005; Näsholm et al., 1998; Schmidt and Stewart, 1999). In Reinkulturen der Pilze wurde die Aufnahme von Aminosäuren vielfach nachgewiesen (Abuzinadah and Read, 1989; Anderson et al., 1999; Dannenmann et al., 2009; Jackson et al., 2008; Keller, 1996; Martin et al., 2008). Ob die direkte Aufnahme organischer Verbindungen allerdings in temperaten Wäldern in situ, d.h. insbesondere unter dem Einfluss der Konkurrenz von mineralisierenden Bakterien, eine wesentliche Rolle spielt, ist unklar. Werden die monomeren organischen Stickstoffverbindungen (Aminosäuren, Aminozucker und Nukleotide) nicht durch Mykorrhizapilze oder direkt von der Pflanze aufgenommen, werden sie über die Prozesse der Ammonifikation und der Nitrifikation zuerst zu Ammonium und dann zu Nitrat reduziert (Abb. 1.2). Die Stickstoffformen Ammonium und Nitrat werden von den mykorrhizierten Wurzelspitzen bei den im Boden vorkommenden $\mathrm{N}$ Konzentrationen meist aktiv aufgenommen(Glass et al., 1992). Die Ammoniumaufnahmeraten von mykorrhizierten Wurzelspitzen der Buche liegen zwischen $0,1-0,7 \mu \mathrm{mol} \mathrm{g}^{-1} \mathrm{fw} \mathrm{h}^{-1}$, die Nitrataufnahmeraten zwischen $0,02-0,17 \mu \mathrm{mol} \mathrm{g}^{-1} \mathrm{fw} \mathrm{h}^{-1}$ (Geßler et al., 2005). Die Aufnahmeraten und das Verhältnis von Ammonium- zu Nitrataufnahme sind stark von der Temperatur abhängig (Geßler et al., 2005). In Experimenten mit markiertem Stickstoff wurde festgestellt, dass je nach Mykorrhizapilzart unterschiedlich viel Stickstoff in den Wurzelspitzen akkumuliert wird und sich damit deren Bedeutung für die Stickstoffversorgung der Pflanze unterscheidet (Pena and Polle, 2013). Da Mykorrhizagesellschaften üblicherweise aus Pilzen unterschiedlicher Explorationstypen gebildet werden, wird eine räumlich (Agerer et al., 2002) und zeitlich (Pena et al., 2013a) gestaffelte Ausbeutung der N-Quellen ermöglicht. Der Kreislauf beginnt erneut, wenn Organismen oder Teile davon absterben und recycelt werden.

Dennoch entstehen zum einen durch Denitrifizierung über die Atmosphäre und zum anderen durch Auswaschung über die Hydrosphäre Stickstoffverluste. Ausgewaschen wird N überwiegend in Form von DON (gelöster organischer Stickstoff) oder leicht löslichem Nitrat (Gessler et al., 1998). Insbesondere nach starken Regenfällen mit vorausgehender Trockenheit kann es zu erheblichen N Verlusten durch Auswaschung kommen, da durch die abgestorbenen Mikroorganismen viel DON freigesetzt wird (Borken and Matzner, 2009). Ammonium findet sich nur in geringen Mengen in der Bodenlösung, da die Ammonifikation langsamer verläuft als die Nitrifikation (Horn et al., 2010). Zusätzlich werden die positiv geladenen Ammoniumionen häufig an Tonmineralen fixiert und sind damit weniger mobil als Nitrationen (Horn et al., 2010). Die Auswaschungsverluste durch Ammonium sind deshalb gering. Die atmosphärischen Stickstoffverluste erfolgen in den verschiedenen Stufen der Denitrifizierung in Form von $\mathrm{NH}_{3}, \mathrm{NO}, \mathrm{N}_{2} \mathrm{O}$ und $\mathrm{N}_{2}$ (Abb. 1.2). Für einen Kalkbuchenwald wurde eine Verlustrate von 1,8 - $6 \mathrm{~kg} \mathrm{~N}_{2}$ ha $^{-1}$ Jahr $^{-1}$ durch die Denitrifikation ermittelt (Dannenmann et al., 2008). 


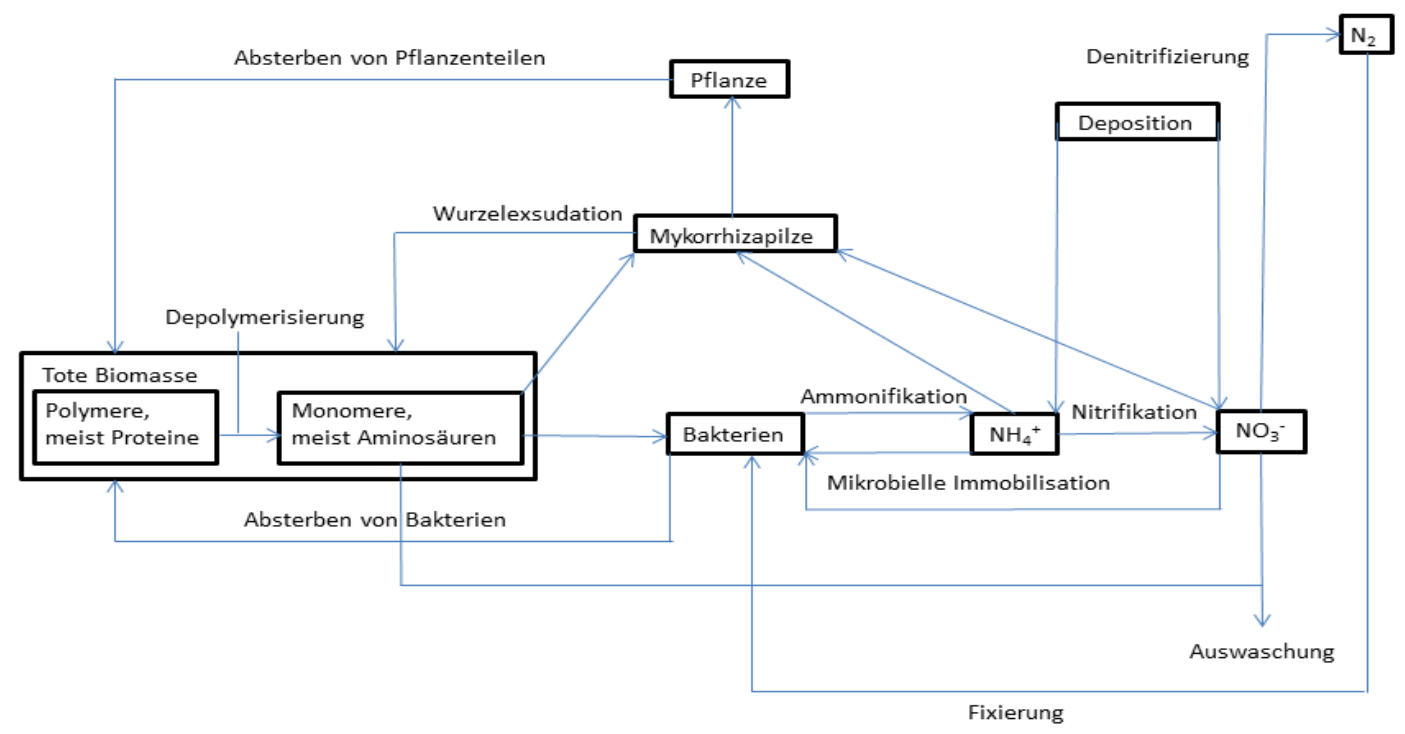

Abbildung 1.2: Der Stickstoffkreislauf in Waldökosystemen (modifiziert nach Rennenberg et al., 2009)

\subsection{Klimawandelbedingte Änderungen im Stickstoffkreislauf der Waldböden können sich auf die Verbreitung und Produktivität der Buchenwälder auswirken}

Die Rotbuche, Fagus sylvatica L., ist in Mitteleuropa weit verbreitet und dominiert die Wälder der potentiellen natürlichen Vegetation (Ellenberg and Leuschner, 1996). Sie ist deshalb nicht nur für die Forstwirtschaft von großer Bedeutung, sondern auch ein wichtiger Bestandteil der Kulturlandschaft (Schraml and Volz, 2004). Sie ist als Schattbaumart sehr konkurrenzstark gegenüber anderen Baumarten und akzeptiert eine große Bandbreite an bodenphysikalischen und -chemischen Beschaffenheiten: Sowohl auf basischen als auch auf sauren Böden, auf Böden mit unterschiedlich guter Nährstoffverfügbarkeit (Leuschner et al., 1993, 2006), in Gebieten mit einer mittleren Jahrestemperatur von 4 bis $12^{\circ} \mathrm{C}$ und einem Jahresniederschlag von 460 bis 2000 mm (Leuschner, 1998) ist sie bestandsbildend präsent. Ihre geographische Verbreitung umfasst West- und Mitteleuropa und die montane Stufe in Süd- und Südosteuropa, wobei sie auf der iberischen Halbinsel und in Griechenland nur in den nördlichen Teilen anzutreffen ist (Röhrig and Dengler, 1992).

In den letzten drei Jahrzehnten wurde die Buche in Deutschland im Rahmen des Waldumbaus von Nadelwäldern stark durch die forstpolitischen Vorgaben gefördert (Tarp et al., 2000). Das Ziel war, einen Wald zu formen, der mit einem hohen Buchenanteil der potentiellen natürlichen Vegetation näher kommt als die bisherigen nadelholzdominierten Wälder. Allerdings beruht das Konzept der potentiellen natürlichen Vegetation auf der Annahme, dass die klimatischen Verhältnisse stabil bleiben (Manthey et al., 2007). Dieses scheint für die Zukunft nicht mehr gegeben zu sein (IPCC, 2007). Die ansteigenden Temperaturen und die zunehmende Frequenz und Länge der Trockenperioden, gefolgt von starken Niederschlägen, können sich auf den Wasser- und Nährstoffhaushalt, auf den Zuwachs und auf das Konkurrenzverhalten von Buchen auswirken (Geßler et al., 2007). Insbesondere Standorte, auf denen das Wachstum der Buchen stickstofflimitiert ist und die Wasserverfügbarkeit niedrig ist, wie auf vielen Kalk- und Sandstandorten, könnten davon 
betroffen sein (Geßler et al., 2007). Dabei wird die erhöhte Jahrestemperatur an sich nicht als vorrangiges Problem angesehen (Bolte, 2005), da z.B. die Ammonifikation und die Nitrifikation bei steigender Temperatur schneller ablaufen (Domisch et al., 2006; Emmett et al., 2004; Hart and Perry, 1999; Harte and Shaw, 1995; Stark and Firestone, 1996). Rustard et al. (2001) stellten in einer Metaanalyse fest, dass bei Bodenerwärmung mit steigender Netto-N-Mineralisierung und damit einhergehendem höheren N-Angebot zu rechnen ist, um das die beteiligten Organismen des Stickstoffkreislaufes dann konkurrieren (Dannenmann et al., 2009; Fotelli et al., 2002, 2005; Geßler et al., 2005). Die erwartete Temperaturerhöhung wird vermutlich nicht in der Lage sein, das Temperaturoptimum (Gessler et al., 1998) der beteiligten Enzyme am Stickstofftransport innerhalb der mykorrhizierten Wurzelspitzen zu überschreiten (Rennenberg et al., 2009).

Das eigentliche Problem stellen wahrscheinlich die vermehrt auftretenden Hitze- und Trockenperioden mit stark absinkender Bodenfeuchte dar (Bolte, 2005). Die Bodenfeuchte ist eine der wichtigsten Größen im Stickstoffhaushalt des Bodens, da die Konzentrationen der einzelnen Stickstoffformen in der Bodenlösung und die Transportvorgänge im Boden von ihr abhängig sind (BassiriRad et al., 1999; Geßler et al., 2005). Die mikrobielle Aktivität nimmt mit steigender Feuchte bis zu einem Optimum zu, das in Kalkbuchenwäldern in Süddeutschland bei ca. 60 - 70 \% Bodenfeuchte liegt (Dannenmann et al., 2006) und sinkt danach wieder ab. Durch den prognostizierten Klimawandel werden vermutlich häufiger Bodenfeuchtewerte unterhalb des Optimums auftreten (Dannenmann et al., 2009). Die Abnahme der mikrobiellen Aktivität mit abnehmender Bodenfeuchte ist durch die zunehmende Dehydrierung der Mikroorganismen zu erklären, die bei Fortdauer bis zu deren Tod führen kann (Borken and Matzner, 2009). Bei anschließender Wiederbewässerung ist häufig ein starker Anstieg von DON zu beobachten. Der Stickstoff wird aus den sich lösenden toten Mikroorganismen freigesetzt (Borken and Matzner, 2009). Zusätzlich können bisher überlebende Mikroorganismen absterben, da durch die Bewässerung sehr starker osmotischer Stress ausgelöst wird (Kieft, 1987). Stickstoffverluste über die Hydrosphere sind die Konsequenz.

Unter trockenen Bedingungen kommt den Mykorrhizapilzen eine besondere Bedeutung zu. Die Vorteile mykorrhizierter Wurzelspitzen sind die Oberflächen- und Reichweitenvergrößerung und der Zugriff der Hyphen auf den Feinporenbereich (Smith and Read, 2010). Es wurde beobachtet, dass unter trockenen Bedingungen das Wasserpotential der mykorrhizierten Pflanzen im Vergleich zu unmykorrhizierten Pflanzen verzögert absinkt (Beniwal et al., 2010; Pena and Polle, 2013). Bei adulten Bäumen im Bestand, die über ein tiefreichendes Wurzelsystem verfügen, könnte die Versorgung der Wirtspflanze mit Nährstoffen von entscheidenderer Bedeutung sein, als die Versorgung der Wirtspflanze mit Wasser (Lehto and Zwiazek, 2011). Ein Hinweis darauf ist, dass mykorrhizierte Buchensämlingen unter trockenen Bedingungen besser mit Stickstoff versorgt werden (Pena et al., 2013b). Unter Bedingungen mit ausreichender Wasserversorgung tritt dieser Effekt nicht auf (Pena and Polle, 2013). Geßler et al. (2005) haben allerdings im Feld unter trockenen Bedingungen eine verminderte Nitrataufnahme mykorrhizierter Wurzelspitzen bei gleichzeitig höheren Ammonifikations- und Nitrifikationsraten feststellen können. Sie vermuten daher, dass nicht die Bereitstellung von anorganischem Stickstoff durch die Bodenbakterien oder veränderte Stickstoff-Allokationsmuster zwischen Bakterien und 
Wurzeln sondern u. A. die reduzierte Aufnahmekapazität für die Zuwachseinbußen verantwortlich sind.

Darüber hinaus ist auch das Konkurrenzverhalten der Naturverjüngung durch die Wasserverfügbarkeit gesteuert. So zeigt die Buchennaturverjüngung Nachteile im Wettbewerb um Stickstoff und Wasser, wenn sie mit schnellwachsenden Unterstand-Arten, z. B. Rubus fruticosus, konkurrieren muss (Fotelli et al., 2001, 2002). Ebenfalls zu starken Zuwachseinbußen der Buchennaturverjüngung führte die Konkurrenz um Wasser mit Grasarten (Coll et al., 2003).

Zusammenfassend könnten diese Effekte in Zukunft zu einer Reduktion des Zuwachses führen. In Buchenaltbeständen der Apenninen wurde dies bereits festgestellt (Piovesan et al., 2008). Nach dem sehr trockenen Sommer im Jahre 2003 wurde auch auf vielen Standorten Mitteleuropas eine starke Reduktion des Zuwachses beobachtet (Ciais et al., 2005). In Nordostspanien, wo Trockenheit für die Verbreitung der Buche limitierend ist, wurde seit 1975 eine starke Verringerung des Wachstums der Buche festgestellt (Buée et al., 2005; Jump et al., 2006). Rennenberg et al. (2004) folgerten daher, dass der einseitig geförderte Anbau der Buche mit einem hohen Risiko behaftet ist. Hanewinkel et al. (2012) prognostizieren, dass sich dass Verbreitungsgebiet der Buche bis zum Jahre 2070 - 2100 in Richtung Norden und Osten verschieben wird, falls die klimatischen Verhältnisse die Buche dort weiterhin begünstigen, während es im südlichen Verbreitungsgebiet trockener wird.

In Mitteleuropa wurde hingegen in vielen Beständen in den letzten Dekaden, vermutlich aufgrund der besseren N Versorgung (Aber et al., 1998) und der verlängerten Vegetationsperiode (Menzel et al., 2006) ein erhöhter Zuwachs festgestellt (Spiecker, 1999). Sehr starke Zuwächse wurden in einer bayernweiten Studie an den wärmsten Standorten der Studie erreicht (Felbermeier, 1994). Hinzu kommt, dass die Buche eine große genetische Variabilität zwischen ihren Beständen aufweist (Chmura and Rozkowski, 2002; Vornam et al., 2004; Von Wuehlisch et al., 1996) und an sehr unterschiedliche Standortverhältnisse angepasst ist (Kölling et al., 2005; Schraml and Rennenberg, 2002). Jedoch gibt es auch innerhalb von Beständen eine hohe genetische Variabilität (Comps et al., 2001; Konnert et al., 2000). So finden sich weit verbreitet bereits trockenheitsangepasste Buchen in der Naturverjüngung (Czajkowski and Bolte, 2006). Dadurch hat die Buche das Potential sich an ändernde Bedingungen anzupassen. Manthey et al. (2007) prognostizieren deshalb, dass sich zwar die ökologische Fitness an den Grenzen des Verbreitungsgebietes und auf flachgründigen Standorten verringert, aber die Buche vorherrschende Baumart in Mitteleuropa bleibt. 


\subsection{Ziele dieser Arbeit}

Die Mykorrhizagesellschaften der Buche sind komplex aus vielen Pilzarten mit unterschiedlicher Abundanz zusammengesetzt und unterliegen einer hohen Dynamik (Buée et al., 2005; Pena et al., 2010). Um solche Mykorrhizagesellschaften untersuchen zu können, ist es entscheidend, die einzelnen Morphotypen mit Hilfe morphologischer und anatomischer Merkmale sicher ansprechen zu können, auch wenn die Identität der Arten im Nachhinein durch molekulare Analysen festgestellt wird. Für die Funktion der Pilze im Ökosystem sind ebenfalls die Morphologie und die Anatomie entscheidend. In Anbetracht von ca. 7000 bis 10000 ektomykorrhizabildenden Pilzen (Taylor and Alexander, 2005), die teilweise mit mehreren Wirtspflanzen Symbiosen eingehen können und somit mehrere Morphotypen ausbilden können, sind bisher nur sehr wenige Morphotypen $(<1000)$ exakt beschrieben und in entsprechenden Datenbanken (DEEMY, EDD) veröffentlicht worden. Im Rahmen der vorliegenden Arbeit wurde daher eine Erstbeschreibung eines Morphotypen, der auf den Probeflächen der nachfolgend genannten Versuche vorkommt, angefertigt.

Ektomykorrhizapilzen kolonisieren die Feinwurzeln von Buchen zu fast $100 \%$ (Pena et al., 2010) und sind daher für die Stickstoffversorgung der Buchen von hoher Bedeutung. Durch ein Experiment unter kontrollierten Bedingungen ohne Stressapplikation soll untersucht werden, ob es nach warmen und trockenen Bedingungen, die eine Anpassung der Bakterien- und Mykorrhizagesellschaften mit sich bringen, eine langfristige Verminderung in der Stickstoffakkumulation in den Mykorrhizen und der Stickstoffaufnahme von Buchennaturverjüngung gibt. Vorausgehende Untersuchungen legen dies nahe (Fotelli et al., 2004; Geßler et al., 2005). Es wurde dafür Buchennaturverjüngung mit deren assoziierten Mykorrhiza- und Bakteriengesellschaften von zwei klimatisch unterschiedlichen Standorten für zwei Monate unter gleichen edaphischen und klimatischen Bedingungen kultiviert. Danach wurde mit markiertem Stickstoff der Verbleib des Stickstoffs in den verschiedenen Pools überprüft und mit den Mykorrhiza- und Bakteriengesellschaften in Beziehung gesetzt.

In einem Freilandversuch soll gezeigt werden, wie sich Mykorrhizagesellschaften in Bezug auf die Stickstoffakkumulation in einem intakten Buche-Mykorrhiza-Mikroben-BodenSystemen verhalten. Insbesondere soll geklärt werden, welche Stickstoffformen in welchem Maße akkumuliert werden und ob sich die Präferenzen für die Stickstoffformen oder das Ausmaß der Akkumulation durch geänderte klimatische Bedingungen verändern. Dafür wurde in Tuttlingen (Baden-Württemberg) Buchennaturverjüngung mit umgebenden Boden in Stahlzylindern von einem NW Hang auf einen SW Hang und von einem NW auf einen NW Hang transferiert. Nach einem Jahr Inkubationszeit wurden die Mesokosmen nach Injizieren von ${ }^{15} \mathrm{~N}$ markierten Stickstoffformen (Glutamin, Ammonium, Nitrat) in den Boden im Juni, August und September unter verschiedenen Bedingungen wie einer vorausgehende Trockenphase oder einem Starkregenereignis geerntet. Der SW-exponierte Standort wies eine höhere Bodentemperatur und eine geringere Bodenfeuchte auf als der NW-Standort und kann somit als Modellstandort für das zukünftig herrschende Klima gelten. Erhöhte Temperaturen, niedrigere Bodenfeuchte und Starkregenereignisse werden für die Zukunft in Mitteleuropa prognostiziert (IPCC, 2007). 


\subsection{Literaturverzeichnis}

Aber J., McDowell W., Nadelhoffer K., Magill A., Berntson G., Kamakea M., McNulty S., Currie W., Rustad L., Fernandez I. 1998. Nitrogen saturation in temperate forest ecosystems. BioScience. 48:921-934.

Abuzinadah R.A., Read D.J. 1986. The role of proteins in the nitrogen nutrition of ectomycorrhizal plants. III. Protein utilization by Betula, Picea and Pinus in mycorrhizal association with Hebeloma crustuliniforme. New Phytol. 507-514.

Abuzinadah R.A., Read D.J. 1989. Carbon transfer associated with assimilation of organic nitrogen sources by silver birch (Betula pendula Roth.). Trees. 3:17-23.

Agerer R., Grote R., Raidl S. 2002. The new method "micromapping", a means to study species-specific associations and exclusions of ectomycorrhizae. Mycol. Prog. 1:155-166.

Agerer R. 1986. Studies on ectomycorrhizae II. Introducing remarks on characterization and identification. Mycotaxon. 473-492.

Agerer R. 1987-2006. Colour Atlas of Ectomycorrhizae. Einhorn Verlag, Schwabisch-Gmünd, Germany.

Agerer R. 1991. Characterization of Ectomycorrhiza. In: Norris J.K., Read D.J., Varma A.K., editors. Methods in Microbiology. Academic Press. p. 25-73.

Agerer R. 1995. Anatomical Characteristics of Identified Ectomycorrhizas: An Attempt Towards a Natural Classification. In: Varma A., Hock B., editors. Mycorrhiza. Springer, Berlin, Heidelberg. p. 685-734.

Agerer R. 2001. Exploration types of ectomycorrhizae. Mycorrhiza. 11:107-114.

Agerer R. 2006. Fungal relationships and structural identity of their ectomycorrhizae. Mycol. Prog. 5:67-107.

Anderson I.C., Chambers S.M., Cairney J.W.G. 1999. Intra- and interspecific variation in patterns of organic and inorganic nitrogen utilization by three Australian Pisolithus species. Mycol. Res. 103:1579-1587.

BassiriRad H., Prior S.A., Norby R.J., Rogers H.H. 1999. A field method of determining $\mathrm{NH}_{4}{ }^{+}$ and $\mathrm{NO}_{3}{ }^{-}$uptake kinetics in intact roots: Effects of $\mathrm{CO}_{2}$ enrichment on trees and crop species. Plant Soil. 217:195-204.

Beimforde C., Schäfer N., Dörfelt H., Nascimbene P.C., Singh H., Heinrichs J., Reitner J., Rana R.S., Schmidt A.R. 2011. Ectomycorrhizas from a Lower Eocene angiosperm forest. New Phytol. 192:988-996.

Bending G.D., Read D.J. 1996a. Nitrogen mobilization from protein-polyphenol complex by ericoid and ectomycorrhizal fungi. Soil Biol. Biochem. 28:1603-1612.

Bending G.D., Read D.J. 1996b. Effects of the soluble polyphenol tannic acid on the activities of ericoid and ectomycorrhizal fungi. Soil Biol. Biochem. 28:1595-1602. 
Beniwal R.S., Langenfeld-Heyser R., Polle A. 2010. Ectomycorrhiza and hydrogel protect hybrid poplar from water deficit and unravel plastic responses of xylem anatomy. Environ. Exp. Bot. 69:189-197.

Berbee M.L., Taylor J.W. 1993. Dating the evolutionary radiations of the true fungi. Can. J. Bot. 71:1114-1127.

Blasius D., Feil W., Kottke I., Oberwinkler F. 1986. Hartig net structure and formation in fully ensheathed ectomycorrhizas. Nord. J. Bot. 6:837-842.

Bolte A. 2005. Zur Zukunft der Buche in Mitteleuropa. AFZ - Wald. 60:1077-1078.

Borken W., Matzner E. 2009. Reappraisal of drying and wetting effects on C and N mineralization and fluxes in soils. Glob. Change Biol. 15:808-824.

Brand F. 1991. Ektomykorrhizen an Fagus sylvatica. Charakterisierung und Identifizierung, Ökologische Kennzeichnung und unsterile Kultivierung. IHW-Verlag, Eching.

Bruchmann H. 1874. Wachstum der Wurzeln von Lycopodium und Isoetes. Jena. Z. Für Naturwissenschaften. 8:522-580.

Brundrett M.C. 1991. Mycorrhizas in natural ecosystems. In: Macfayden A., Begon M., Fitter A.H., editors. Mycorrhizas in natural ecosystems. Academic Press, London.

Brundrett M.C. 2002. Coevolution of roots and mycorrhizas of land plants. New Phytol. 154:275-304.

Buée M., Vairelles D., Garbaye J. 2005. Year-round monitoring of diversity and potential metabolic activity of the ectomycorrhizal community in a beech (Fagus silvatica) forest subjected to two thinning regimes. Mycorrhiza. 15:235-245.

Chapman S.K., Langley J.A., Hart S.C., Koch G.W. 2006. Plants actively control nitrogen cycling: uncorking the microbial bottleneck. New Phytol. 169:27-34.

Chmura D.J., Rozkowski R. 2002. Variability of beech provenances in spring and autumn phenology. Silvae Genet. 51:123-127.

Ciais P., Reichstein M., Viovy N., Granier A., Ogée J., Allard V., Aubinet M., Buchmann N., Bernhofer C., Carrara A., Chevallier F., De Noblet N., Friend A.D., Friedlingstein P., Grünwald T., Heinesch B., Keronen P., Knohl A., Krinner G., Loustau D., Manca G., Matteucci G., Miglietta F., Ourcival J.M., Papale D., Pilegaard K., Rambal S., Seufert G., Soussana J.F., Sanz M.J., Schulze E.D., Vesala T., Valentini R. 2005. Europe-wide reduction in primary productivity caused by the heat and drought in 2003. Nature. 437:529533.

Cleveland C.C., Townsend A.R., Schimel D.S., Fisher H., Howarth R.W., Hedin L.O., Perakis S.S., Latty E.F., Von Fischer J.C., Elseroad A. 1999. Global patterns of terrestrial biological nitrogen $\left(\mathrm{N}_{2}\right)$ fixation in natural ecosystems. Glob. Biogeochem. Cycles. 13:623-645. . Clowes F.A.L. 1951. The structure of mycorrhizal roots of Fagus sylvatica. New Phytol. 50:116.

Coll L., Balandier P., Picon-Cochard C., Prevosto B., Curt T. 2003. Competition for water between beech seedlings and surrounding vegetation in different light and vegetation composition conditions. Ann. For. Sci. 60:593-600. 
Comps B., Gömöry D., Letouzey J., Thiébaut B., Petit R.J. 2001. Diverging trends between heterozygosity and allelic richness during postglacial colonization in the European beech. Genetics. 157:389-397.

Cullings K., Courty P.-E. 2009. Saprotrophic capabilities as functional traits to study functional diversity and resilience of ectomycorrhizal community. Oecologia. 161:661-664.

Czajkowski T., Bolte A. 2006. Unterschiedliche Reaktion deutscher und polnischer Herkünfte der Buche (Fagus sylvatica L.) auf Trockenheit. Allg Forst Jagdztg. 177:30-40.

Dannenmann M., Butterbach-Bahl K., Gasche R., Willibald G., Papen H. 2008. Dinitrogen emissions and the $\mathrm{N}_{2}: \mathrm{N}_{2} \mathrm{O}$ emission ratio of a Rendzic Leptosol as influenced by $\mathrm{pH}$ and forest thinning. Soil Biol. Biochem. 40:2317-2323.

Dannenmann M., Gasche R., Ledebuhr A., Papen H. 2006. Effects of forest management on soil N cycling in beech forests stocking on calcareous soils. Plant Soil. 287:279-300.

Dannenmann M., Simon J., Gasche R., Holst J., Naumann P.S., Kögel-Knabner I., Knicker H., Mayer H., Schloter M., Pena R., Polle A., Rennenberg H., Papen H. 2009. Tree girdling provides insight on the role of labile carbon in nitrogen partitioning between soil microorganisms and adult European beech. Soil Biol. Biochem. 41:1622-1631.

Dighton J. 2007. Nutrient cycling by saprotrophic fungi in terrestrial habitats. Mycota Environ. Microb. Relatsh. IV. 4:287.

Domisch T., Finér L., Laine J., Laiho R. 2006. Decomposition and nitrogen dynamics of litter in peat soils from two climatic regions under different temperature regimes. Eur. J. Soil Biol. 42:74-81.

Ellenberg H., Leuschner C. 1996. Vegetation Mitteleuropas mit den Alpen in ökologischer, dynamischer und historischer Sicht. Ulmer, Stuttgart, Germany.

Emmett B.A., Beier C., Estiarte M., Tietema A., Kristensen H.L., Williams D., Penuelas J., Schmidt I., Sowerby A. 2004. The response of soil processes to climate change: results from manipulation studies of shrublands across an environmental gradient. Ecosystems. 7:625637.

Felbermeier B. 1994. Die klimatische Belastbarkeit der Buche. Forstwiss. Cent. 113:152174.

Finzi A.C., Berthrong S.T. 2005. The uptake of amino acids by microbes and trees in three cold-temperate forests. Ecology. 86:3345-3353.

Fotelli M.N., Geßler A., Peuke A.D., Rennenberg H. 2001. Drought affects the competitive interactions between Fagus sylvatica seedlings and an early successional species, Rubus fruticosus: responses of growth, water status and $\delta^{13} \mathrm{C}$ composition. New Phytol. 151:427435.

Fotelli M.N., Rennenberg H., Geßler A. 2002. Effects of drought on the competitive interference of an early successional species (Rubus fruticosus) on Fagus sylvatica $\mathrm{L}$. seedlings: ${ }^{15} \mathrm{~N}$ uptake and partitioning, responses of amino acids and other $\mathrm{N}$ compounds. Plant Biol. 4:311-320. 
Fotelli M.N., Rienks M., Rennenberg H., Geßler A. 2004. Climate and forest management affect ${ }^{15} \mathrm{~N}$-uptake, $\mathrm{N}$ balance and biomass of European beech seedlings. Trees. 18:157-166.

Fotelli M.N., Rudolph P., Rennenberg H., Geßler A. 2005. Irradiance and temperature affect the competitive interference of blackberry on the physiology of European beech seedlings. New Phytol. 165:453-462.

Frank A.B. 1885. Ueber die auf Wurzelsymbiose beruhende Ernährung gewisser Bäume durch unterirdische Pilze. Berichte Dtsch. Bot. Ges. III:128-145.

Frey-Klett P., Garbaye J., Tarkka M. 2007. The mycorrhiza helper bacteria revisited. New Phytol. 176:22-36.

Genet P., Prevost A., Pargney J.C. 2000. Seasonal variations of symbiotic ultrastructure and relationships of two natural ectomycorrhizae of beech (Fagus sylvatica/Lactarius blennius var. viridis and Fagus sylvatica/Lactarius subdulcis). Trees. 14:465-474.

Geßler A., Jung K., Gasche R., Papen H., Heidenfelder A., Börner E., Metzler B., Augustin S., Hildebrand E., Rennenberg H. 2005. Climate and forest management influence nitrogen balance of European beech forests: microbial $\mathrm{N}$ transformations and inorganic $\mathrm{N}$ net uptake capacity of mycorrhizal roots. Eur. J. For. Res. 124:95-111.

Geßler A., Keitel C., Kreuzwieser J., Matyssek R., Seiler W., Rennenberg H. 2007. Potential risks for European beech (Fagus sylvatica L.) in a changing climate. Trees. 21:1-11.

Geßler A., Schneider S., Von Sengbusch D., Weber P., Hanemann U., Huber C., Rothe A., Kreutzer K., Rennenberg H. 1998. Field and laboratory experiments on net uptake of nitrate and ammonium by the roots of spruce (Picea abies) and beech (Fagus sylvatica) trees. New Phytol. 138:275-285.

Glass A.D., Shaff J.E., Kochian L.V. 1992. Studies of the uptake of nitrate in barley IV. Electrophysiology. Plant Physiol. 99:456-463.

Godbout C., Fortin J.A. 1983. Morphological features of synthesized ectomycorrhizae of Alnus crispa and A. rugosa. New Phytol. 94:249-262.

Hanewinkel M., Cullmann D.A., Schelhaas M.-J., Nabuurs G.-J., Zimmermann N.E. 2013. Climate change may cause severe loss in the economic value of European forest land. Nat. Clim. Change. 3:203-207.

Harley J.L., McCready C.C. 1952. The uptake of phosphorus by excised mycorrhizal roots of beech. III. The effect of the fungal sheath on the availability of phosphate to the core. New Phytol. 51:343-348.

Harley J.L., Smith S.E. 1983. Mycorrhizal symbiosis. London: Academic Press . Hart S.C., Perry D.A. 1999. Transferring soils from high-to low-elevation forests increases nitrogen cycling rates: climate change implications. Glob. Change Biol. 5:23-32.

Harte J., Shaw R. 1995. Shifting dominance within a montane vegetation community: results of a climate-warming experiment. Science. 267:876-880.

Horn R., Brümmer G.W., Kandeler E., Kögel-Knabner I., Kretzschmar R., Stahr K., Wilke B.M. 2010. Scheffer/Schachtschabel: Lehrbuch der Bodenkunde. Springer, Germany. 
Jackson L.E., Burger M., Cavagnaro T.R. 2008. Roots, nitrogen transformations and ecosystem services. Plant Biol. 59:341.

Jump A.S., Hunt J.M., Martínez-Izquierdo J.A., Peñuelas J. 2006. Natural selection and climate change: temperature-linked spatial and temporal trends in gene frequency in Fagus sylvatica. Mol. Ecol. 15:3469-3480.

Kammerbauer H., Agerer R., Jr H.S. 1989. Studies on ectomycorrhiza. Trees. 3:78-84.

Keller G. 1996. Utilization of inorganic and organic nitrogen sources by high-subalpine ectomycorrhizal fungi of Pinus cembra in pure culture. Mycol. Res. 100:989-998.

Kieft T.L. 1987. Microbial biomass response to a rapid increase in water potential when dry soil is wetted. Soil Biol. Biochem. 19:119-126.

Kölling C., Walentowski H., Borchert H. 2005. Die Buche in Mitteleuropa. AFZ - Wald. 13:696-701.

Konnert M., Ziehe M., Tröber U., Maurer W., Janßen A., Sander T., Hussendörfer E., Hertel H. 2000. Genetische Variation der Buche (Fagus sylvatica) in Deutschland: Gemeinsame Auswertung genetischer Inventuren über verschiedene Bundesländer. Forst Holz. 55:403406.

Kottke I., Oberwinkler F. 1986. Mycorrhiza of forest trees - structure and function. Trees. $1: 1-24$.

Lehto T., Zwiazek J.J. 2011. Ectomycorrhizas and water relations of trees: a review. Mycorrhiza. 21:71-90.

Leuschner C., Meier I.C., Hertel D. 2006. On the niche breadth of Fagus sylvatica: soil nutrient status in 50 Central European beech stands on a broad range of bedrock types. Ann. For. Sci. 63:355-368.

Leuschner C., Rode M.W., Heinken T. 1993. Gibt es eine Nährstoffmangel-Grenze der Buche im nordwestdeutschen Flachland? Flora. 188:239-249.

Leuschner C. 1998. Mechanismen der Konkurrenzüberlegenheit der Rotbuche. Ber. Reinh. Tüxen Ges. 10:5-18.

Lovett G.M., Weathers K.C., Arthur M.A., Schultz J.C. 2004. Nitrogen cycling in a northern hardwood forest: Do species matter? Biogeochemistry. 67:289-308.

Lussenhop J., Fogel R. 1999. Seasonal change in phosphorus content of Pinus strobus: Cenococcum geophilum ectomycorrhizae. Mycologia. 91:742.

Mangin L. 1910. Introduction a l'etude des Mycorhizes des arbres forestiers. Nouvelles Archives du Museum d'Histoire Naturelle, Paris.

Manthey M., Leuschner C., Härdtle W. 2007. Buchenwälder und Klimawandel. Nat. Landsch. 82:441-445.

Martin F., Aerts A., Ahrén D., Brun A., Danchin E.G.J., Duchaussoy F., Gibon J., Kohler A., Lindquist E., Pereda V. 2008. The genome of Laccaria bicolor provides insights into mycorrhizal symbiosis. Nature. 452:88-92. 
Menzel A., Sparks T.H., Estrella N., Koch E., Aasa A., Ahas R., Alm-Kübler K., Bissolli P., Braslavská O., Briede A., Chmielewski F.M., Crepinsek Z., Curnel Y., Dahl Å., Defila C., Donnelly A., Filella Y., Jatczak K., Måge F., Mestre A., Nordli Ø., Peñuelas J., Pirinen P., Remišová V., Scheifinger H., Striz M., Susnik A., Van Vliet A.J.H., Wielgolaski F.-E., Zach S., Zust A. 2006. European phenological response to climate change matches the warming pattern. Glob. Change Biol. 12:1969-1976.

Meyer F.H. 1973. Distribution of ectomycorrhizae in native and man-made forests. In: Marks G.H., Kozlowski T.T. (eds.) Ectomycorrhizae, their ecologie and physiology. Acad. Press, New York. 79-105.

Molina R., Massicotte H., Trappe J.M. 1992. Specificity phenomena in mycorrhizal symbioses: community-ecological consequences and practical implications. Mycorrhizal Funct. Integr. Plant-Fungal Process. 357-423.

Näsholm T., Ekblad A., Nordin A., Giesler R., Högberg M., Högberg P. 1998. Boreal forest plants take up organic nitrogen. Nature. 392:914-916.

IPCC 2007. Climate Change 2007: Impacts, Adaptation and Vulnerability: Working Group II Contribution to the Fourth Assessment Report of the IPCC Intergovernmental Panel on Climate Change. Cambridge University Press.

Pena R., Offermann C., Simon J., Naumann P.S., Geßler A., Holst J., Dannenmann M., Mayer H., Kogel-Knabner I., Rennenberg H., Polle A. 2010. Girdling affects ectomycorrhizal fungal (EMF) diversity and reveals functional differences in EMF community composition in a beech forest. Appl. Environ. Microbiol. 76:1831-1841.

Pena R., Polle A. 2013. Attributing functions to ectomycorrhizal fungal identities in assemblages for nitrogen acquisition under stress. ISME J. doi:10.1038/ismej.2013.158.

Pena R., Simon J., Rennenberg H., Polle A. 2013a. Ectomycorrhiza affect architecture and nitrogen partitioning of beech (Fagus sylvatica L.) seedlings under shade and drought. Environ. Exp. Bot. 87:207-217.

Pena R., Tejedor J., Zeller B., Dannenmann M., Polle A. 2013b. Interspecific temporal and spatial differences in the acquisition of litter-derived nitrogen by ectomycorrhizal fungal assemblages. New Phytol. 199:520-528.

Peyronel B. 1960. Mykorrhizenstruktur und mykorrhizogene Pilze. In: Rawald W., editor. Mykorrhiza: Internationales Mykorrhizasymposium Weimar. Fischer, Jena p. 15-25.

Piovesan G., Biondi F., Filippo A.D., Alessandrini A., Maugeri M. 2008. Drought-driven growth reduction in old beech (Fagus sylvatica L.) forests of the central Apennines, Italy. Glob. Change Biol. 14:1265-1281.

Read D.J., Perez-Moreno J. 2003. Mycorrhizas and nutrient cycling in ecosystems-a journey towards relevance? New Phytol. 157:475-492.

Read D.J. 1992. The Mycorrhizal Mycelium DJ Read. Mycorrhizal Funct. Integr. Plant-Fungal Process. 1102. 
Rennenberg H., Dannenmann M., Geßler A., Kreuzwieser J., Simon J., Papen H. 2009. Nitrogen balance in forest soils: nutritional limitation of plants under climate change stresses. Plant Biol. 11:4-23.

Rennenberg H., Geßler A. 1999. Consequences of N deposition to forest ecosystemsRecent results and future research needs. Water. Air. Soil Pollut. 116:47-64.

Rennenberg H., Seiler W., Matyssek R., Geßler A., Kreuzwieser J. 2004. Die Buche (Fagus sylvatica) - ein Waldbaum ohne Zukunft im südlichen Mitteleuropa? Allg. Forst- Jagdztg. 175:210-224.

Rinaldi A.C., Comandini O. 2008. Ectomycorrhizal fungal diversity: seperating the wheat from the chaff. Fungal Divers. 332008.

Röhrig E., Dengler A. 1992. Waldbau auf ökologischer Grundlage 1 1. Hamburg u.a.: Parey . Rousseau J.V.D., Reid C.P.P., English R.J. 1992. Relationship between biomass of the mycorrhizal fungus Pisolithus tinctorius and phosphorus uptake in loblolly pine seedlings. Soil Biol. Biochem. 24:183-184.

Rustad L., Campbell J., Marion G., Norby R., Mitchell M., Hartley A., Cornelissen J., Gurevitch J. 2001. A meta-analysis of the response of soil respiration, net nitrogen mineralization, and aboveground plant growth to experimental ecosystem warming. Oecologia. 126:543-562.

Sangwanit U. 1986. Amino acid uptake by mycorrhizal and non mycorrhizal Douglas fir and Western Hemlock seedlings. University of Washington.

Schimel J.P., Bennett J. 2004. Nitrogen mineralization: challenges of a changing paradigm. Ecology. 85:591-602.

Schmidt S., Stewart G.R. 1999. Glycine metabolism by plant roots and its occurrence in Australian plant communities. Funct. Plant Biol. 26:253-264.

Schraml C., Rennenberg H. 2002. Ökotypen der Rotbuche (Fagus sylvatica L.) zeigen unterschiedliche Reaktionen auf Trockenstreß. Forstwiss. Cent. ver. mit Tharandter Forstl. Jahrb. 121:59-72.

Schraml U., Volz K.-R. 2004. Conversion of coniferous forests in social and political perspectives. Findings from selected countries with special respect to Germany. In: Spiecker H., Klimo E., Skovsgaard J., v. Teuffel K., editors. The question of conversion of pure secondary Norway spruce forests on sites naturally dominated by broadleaves for sustainable fulfilment of society's needs. Leiden: S. Brill. p. 97-119.

Schramm J.R. 1966. Plant colonization studies on black wastes from anthracite mining in Pennsylvania. Transcr. Am. Philos. Soc. 56:1-194.

Smith S.E., Read D.J. 2010. Mycorrhizal Symbiosis. Academic Press.

Spiecker H. 1999. Overview of recent growth trends in European forests. Water. Air. Soil Pollut. 116:33-46.

Stark J.M., Firestone M.K. 1996. Kinetic characteristics of ammonium-oxidizer communities in a California oak woodland-annual grassland. Soil Biol. Biochem. 28:1307-1317. 
Tarp P., Helles F., Holten-Andersen P., Bo Larsen J., Strange N. 2000. Modelling nearnatural silvicultural regimes for beech-an economic sensitivity analysis. For. Ecol. Manag. 130:187-198.

Taylor A.F., Alexander I.A.N. 2005. The ectomycorrhizal symbiosis: life in the real world. Mycologist. 19:102-112.

Taylor T.N., Remy W., Hass H., Kerp H. 1995. Fossil arbuscular mycorrhizae from the Early Devonian. Mycologia. 560-573.

Thomson B.D., Grove T.S., Malajczuk N., Hardy G.E.S.J. 1994. The effectiveness of ectomycorrhizal fungi in increasing the growth of Eucalyptus globulus Labill. in relation to root colonization and hyphal development in soil. New Phytol. 126:517-524.

Tietema A., Beier C. 1995. A correlative evaluation of nitrogen cycling in the forest ecosystems of the EC projects NITREX and EXMAN. For. Ecol. Manag. 71:143-151.

Trappe J.M. 2005. AB Frank and mycorrhizae: the challenge to evolutionary and ecologic theory. Mycorrhiza. 15:277-281.

Unestam T., Sun Y.-P. 1995. Extramatrical structures of hydrophobic and hydrophilic ectomycorrhizal fungi. Mycorrhiza. 5:301-311.

Vogt K.A., Edmonds R.L., Grier C.C. 1981. Seasonal changes in biomass and vertical distribution of mycorrhizal and fibrous-textured conifer fine roots in 23- and 180-year-old subalpine Abies amabilis stands. Can. J. For. Res. 11:224-230.

Vogt K.A., Grier C.C., Meier C.E., Edmonds R.L. 1982. Mycorrhizal role in net primary production and nutrient cycling in Abies amabilis ecosystems in Western Washington. Ecology. 370-380.

Vogt K.A., Publicover D.A., Vogt D.J. 1991. A critique of the role of ectomycorrhizas in forest ecology. Agric. Ecosyst. Environ. 35:171-190.

Vornam B., Decarli N., Gailing O. 2004. Spatial distribution of genetic variation in a natural beech stand (Fagus sylvatica L.) based on microsatellite markers. Conserv. Genet. 5:561570.

Withington J.M., Reich P.B., Oleksyn J., Eissenstat D.M. 2006. Comparisons of structure and life span in roots and leaves among temperate trees. Ecol. Monogr. 76:381-397.

Von Wuehlisch G., Krusche D., Muhs H.J. 1996. Variation in temperature sum requirement for flushing of beech provenances. Silvae Genet. 44:343-345. 


\title{
2 „Fagirhiza inflata“ + Fagus sylvatica L.
}

\author{
Martin Leberecht ${ }^{A}$, Andrea Polle ${ }^{A}$, Reinhard Agerer ${ }^{B}$

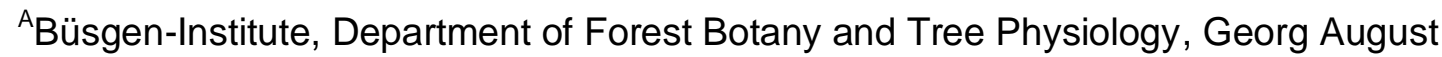 \\ University Göttingen, Büsgenweg 2, D-37077 Germany; \\ ${ }^{B}$ Department Biology I and GeoBio-Center LMU, Organismic Biology: Mycology, University of \\ München, Menzinger Str. 67, D-80638 München, Germany
}

Published 2012 in Descriptions of Ectomycorrhizae 13:39-43

\subsection{Short description}

This ectomycorrhiza has an orangish ochre colour, a monopodial pinnate to pyramidal ramification and is densely cottony covered by cystidia. These cystidia are at the polytomies three- to sixfold furcated and there characteristically inflated. Outer mantle layers are plectenchymatous and gelatinous, formed by irregularly shaped cells and covered by a hyphal net embedded in a gelatinous matrix. Middle mantle layers are between plectenchymatous and pseudoparenchymatous with irregularly shaped hyphae. The cells of the inner mantle layer are orientated in parallel. Mantle and cystidia show a dextrinoid reaction with Melzer's reagent.

\subsection{Characterization of "Faghiriza inflata"}

\subsubsection{Morphological characters (Fig. 2.1a)}

Mycorrhizal system monopodial, pinnate to pyramidal, with one order of ramification, laying mostly between old leaves. - Main axes up to $15 \mathrm{~mm}$ long, $0.2-0.4 \mathrm{~mm}$ diam. - Unramified ends straight to bent, $0.5-1.5(3) \mathrm{mm}$ long, $0.2-0.3$ diam., cylindric, sometimes slightly inflated at middle parts, orange-ochre, at tips partly with some darker bands, older parts brownish grey; hydrophilic, of the short-distance exploration type - Surface of unramified ends at the tip smooth with some cystidia, in the middle and basal densely cottony and covered with soil particles. - Rhizomorphs not observed. - Sclerotia not observed.

\subsubsection{Anatomical characters of mantle in plan views (Fig. 2.2)}

Mantle with three distinct layers, hyphae colourless. Clamps lacking. - Outer mantle layers (Fig. 2 a) plectenchymatous, gelatinous, with irregularly shaped hyphae, sometimes star-like arranged, hyphal cells 10-30 $\mu \mathrm{m}$ long, 2-4.5 $\mu \mathrm{m}$ diam., walls 0.2-0.3 $\mu \mathrm{m}$ thick, covered by an irregularly shaped hyphal net from which ramified cystidia originate, hyphal net cells $20-50$ $\mu \mathrm{m}$ long, 2-5 $\mu \mathrm{m}$ diam., walls 0.2-0.4 $\mu \mathrm{m}$ thick, matrix between net and outer mantle layer, many adhering soil particles. - Middle mantle layers (Fig. 2.2 b) a transition type between plectenchymatous and pseudoparenchymatous, irregularly shaped cells, sometimes with very big cells, hyphal cells 10-25(70) $\mu \mathrm{m}$ long, 1.5-3.5 $\mu \mathrm{m}$ diam., walls $0.25-0.5 \mu \mathrm{m}$ thick. Inner mantle layers (Figs. $2.2 \mathrm{c}$ ) transitional type between plectenchymatous and pseudoparenchymatous, hyphae orientated in parallel and slightly bent, irregularly shaped, hyphal cells $12-32 \mu \mathrm{m}$ long, 1.5-2.25 $\mu \mathrm{m}$ diam., walls $0.2-0.25 \mu \mathrm{m}$ thick. - Very tip similar to the other areas. 


\subsubsection{Anatomical characters of emanating elements (Figs. 2.1b, c)}

Lacking are clamps, anastomoses not found. - Rhizomorphs lacking. - Emanating hyphae lacking. - Cystidia (Fig. 2.1c), originating in the hyphal net of the outer mantle layers, with polytomous ramifications with $3-6$ branches, mostly characteristically inflated at the points of ramifications (Fig. 1b), main hypha (2.5)3.5(5) $\mu \mathrm{m}$ diam., (50)200(500) $\mu \mathrm{m}$ distance between polytomies, branches 1.5 - $3 \mu \mathrm{m}$ diam., cell walls $0.2-0.5 \mu \mathrm{m}$ thick, surface smooth, distal ends needle-like, colourless, septa rare. Chlamydospores not observed.

\subsubsection{Colour reaction with different reagents}

Mantle and Cystidia preparations: Melzer's reagent: dextrinoid

\subsubsection{Autofluorescence}

Not tested.

\subsubsection{DNA-Analysis}

DNA of some mycorrhized root tips was extracted using the innuPREP DNA Kit (Analytik Jena, Jena, Germany) as recommended by the manufacturer. The ITS region was amplified using the PCR primers ITS1F (Gardes and Bruns 1993) and ITS4 (White et al. 1990). The obtained PCR product was purified with sodium acetate. Sequencing was performed by the sequencing service of the Büsgen-Institute, Department Forest Genetics and Forest Tree Breeding of the Georg August Univerity Göttingen using Big Dye Terminator 3.1 Cycles Sequencing Kit (applied Biosystems, Foster City, USA). The sequences were assembled with StadenPackage V4.10 and registered in the NCBI GenBank with the accession number JN701901. A BlastN search in GenBank showed that this fungus belongs to the genus Sebacina. The sequence of Fagirhiza inflata is identical with the sequence FR852335 (uncultured Sebacina, Identities 593/593 (100\%), Score 1104, E value 0.0, belonging to a related project near the location of Fagirhiza inflata). A sequence of Sebacina incrustans (UDB000118, Identities 563/633 (88\%), Score 644, E value 0.0 ) is the best hit with an identified fungus.

\subsubsection{Reference specimen for Fagus sylvatica ectomycorrhiza}

Germany, Baden-Württemberg, Tuttlingen, Forest near Möhringen, coord.: N47.975609, E8.753881, 15.5.11, ML1 in FEA (Göttingen, Germany); beech dominated forest, low mountain range, altitude $690 \mathrm{~m}$ a.s.l., NE-slope, rendzic leptosols; Identification of mycorrhiza as a member of Sebacina by DNA Analysis (see above) and morphological features (Agerer and Rambold 2004-2011); ectomycorrhiza exc., isol. and ident. M. Leberecht.

\subsection{Discussion}

Anatomical and morphological features like the characteristic form of cystidia and the lack of clamps and rhizomorphs suggest a classification of this ectomycorrhiza as a member of the genus Sebacina (Agerer and Rambold 2004-2011). Sequence analysis of the rDNA ITS region confirmed this affiliation. 
Members of the genus Sebacina are known for their ability to form ecto-, orchid, ericoid, and jungermannioid mycorrhizae (Weiss et al. 2004). They produce ectomycorrhizae on angiosperms (Glen et al. 2002; Selosse et al. 2002; Avis et al. 2003; Urban et al. 2003;

Richard et al. 2005; Tedersoo et al. 2006; Smith et al. 2007) and gymnosperms (Urban et al. 2003, 2008; Obase et al. 2009).

Five ectomycorrhizae from this genus have been described (Agerer and Rambold 20042011). Four of them do not have hyphae orientated in parallel in the inner the mantle layer. Some additional differences enable a differentiation of Fagirhiza inflata from the other sebacinoid ectomycorrhizae (s. below).

Sebacina incrustans (Pers.) Tul. \& C.Tul on Picea abies (Urban et al. 2003) has shorter Cystidia $(150 \mu \mathrm{m})$. The ramifications of the hyphae are often only Y-shaped. Polytomies with three branches are rare. Quercirhiza dendrohyphidiomorpha on Quercus suber (Azul et al. 2006) has hyphae with elbow-like structures. The cystidia or hyphae have no inflated ramification points and no polytomies with more than 3 branches. Pinirhiza multifurcata on Pinus tabulaeformis Carr. (Wei and Agerer 2011) has thicker walls $(0.3-0.8 \mu \mathrm{m})$ of emanating hyphae. They are not so strongly inflated at the ramification points, and have only polytomies with 3 branches. Pinirhiza nondextrinoidea on Pinus tabulaeformis Carr. (Wei and Agerer 2011) has simple rhizomorphs and no cystidia. The ramification of the hyphae is Y-shaped and the ramification points are often not inflated. There is no dextrinoid reaction with Melzer's Reagent. The only known ectomycorrhiza of Sebacina with parallel hyphal arrangement in the inner mantle is Sebacinoid sp. on Tilia sp. (Urban et al. 2003) or, as a synonym, Tiliaerhiza sebacinoides (Agerer and Rambold 2004-2011).

High similarities of the sequence (AF509964, Identities 590/603 (97\%), Score 1070, E value 0.0 ) suggest a close relation of $F$. inflata and T. sebacinoides. Some morpho-anatomical differences identify F. inflata, however, as a separate ectomycorrhiza. The cells of the superficial net are larger in diam. with 3.5-7 $\mu \mathrm{m}$ in comparison to those of $F$. inflata with 2-5 $\mu \mathrm{m}$. In the inner mantle the hyphae of $\mathrm{T}$. sebacinoides are often ramified in $\mathrm{Y}$-shape and have thinner cell walls $(<0.2 \mu \mathrm{m})$, but they are arranged in parallel like in F. inflata. The emanating hyphae have polytomies with only 3 - 4 branches and their cell walls are thicker (up to $1.3 \mu \mathrm{m}$ ), as compared to $3-6$ branches and a cell wall thickness of $0.2-0.5 \mu \mathrm{m}$, respectively, in $\mathrm{F}$. inflata.

\subsection{Acknowledgments}

We thank Thomas Klein (LARI, Labor für Radioisotope, Göttingen) for extracting and amplifying the fungal DNA. This study was financially supported by DFG (Deutsche Forschungsgemeinschaft, Po 361/19-1). 

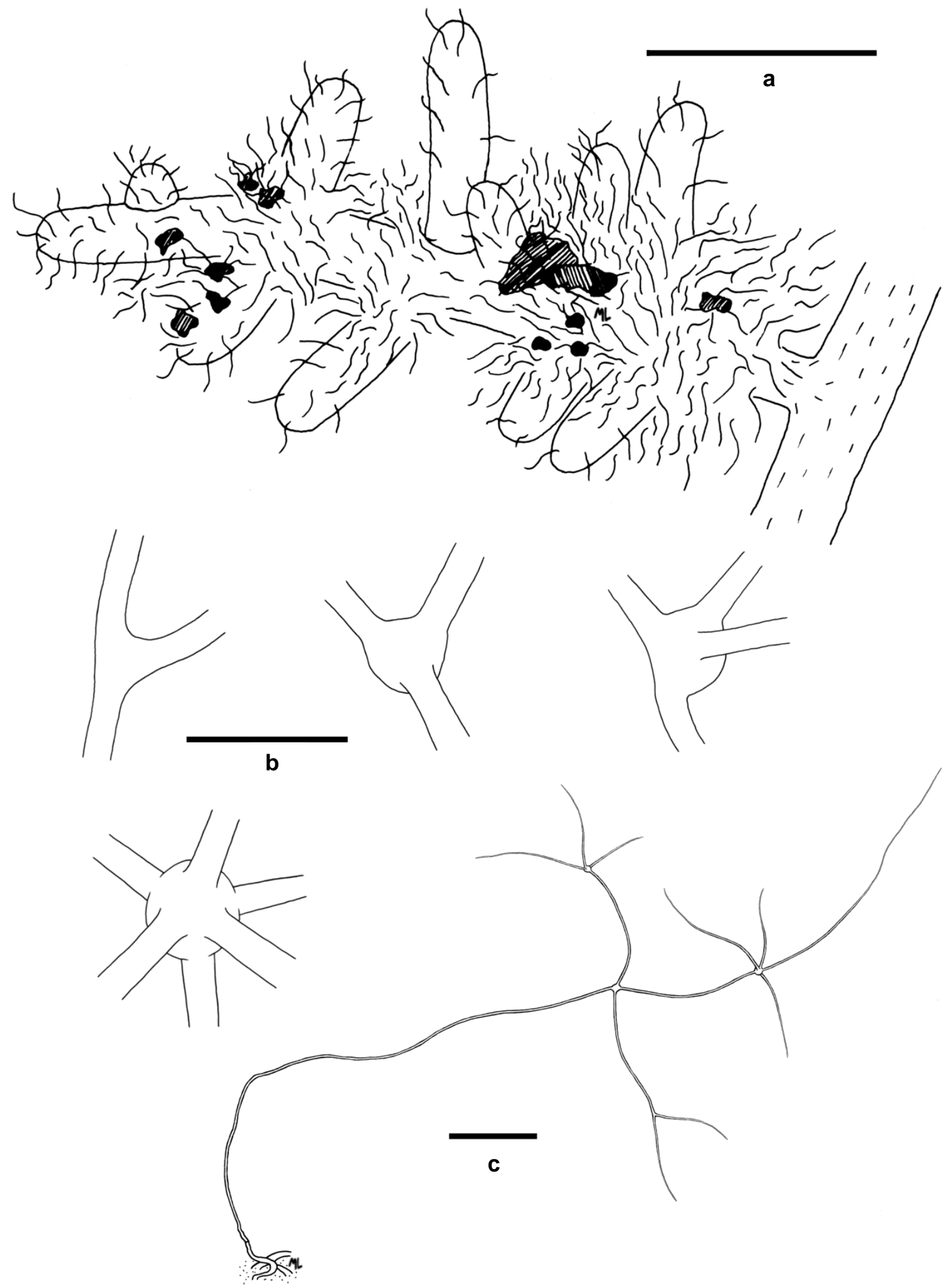

Figure 2.1: a) Habit of the mycorrhiza (bar $1 \mathrm{~mm}$ ). b) Different ramification forms of the cystidia (bar $10 \mu \mathrm{m}) . \mathrm{c})$ Complete cystidia (bar $100 \mu \mathrm{m}$ ) 

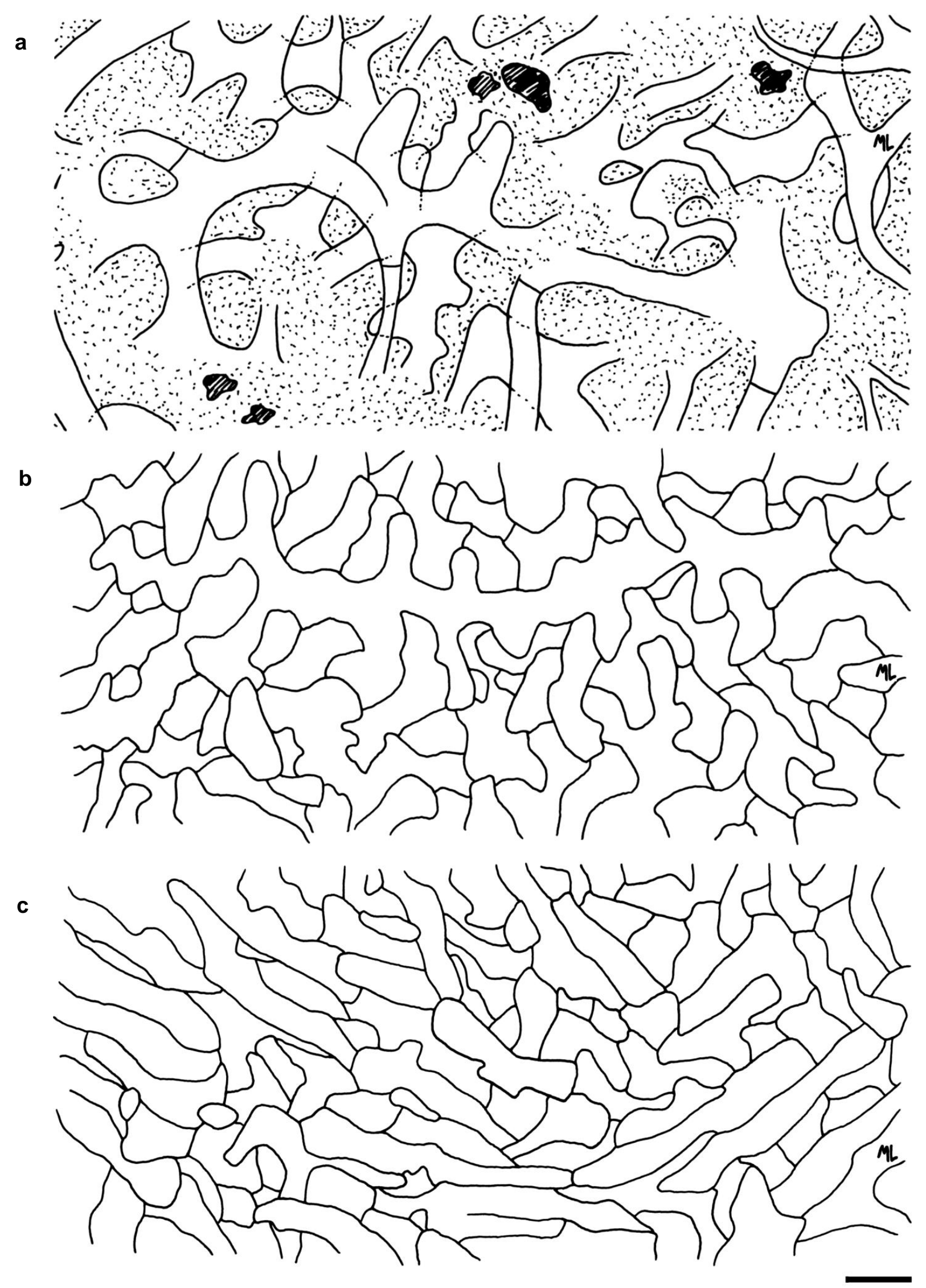

Figure 2.2: a) Structure of the outer mantle layers b) Structure of the middle mantle layers. c) Structure of the inner mantle layers (bar $5 \mu \mathrm{m})$. 


\subsection{References}

Agerer R., Rambold G. 2004. DEEMY - An information system for characterization and determination of ectomycorrhizae. www.deemy.de - München, Germany.

Avis P.G., McLaughlin D.J., Dentinger B.C., Reich P.B. 2003. Long-term increase in nitrogen supply alters above- and below-ground ectomycorrhizal communities and increases the dominance of Russula spp. in a temperate oak savanna. New Phytol. 160:239-253.

Azul A., Agerer R., Freitas H. 2006. "Quercirhiza dendrohyphidiomorpha" + Quercus suber L. Descr. Ectomycorrhizae. 9/10:87-91.

Gardes M., Bruns T.D. 1993. ITS primers with enhanced specificity for basidiomycetes application to the identification of mycorrhizae and rusts. Mol. Ecol. 2:113-118.

Glen M., Tommerup I.C., Bougher N.L., O’Brien P.A. 2002. Are Sebacinaceae common and widespread ectomycorrhizal associates of Eucalyptus species in Australian forests? Mycorrhiza. 12:243-247.

Obase K., Cha J.Y., Lee J.K., Lee S.Y., Lee J.H., Chun K.W. 2009. Ectomycorrhizal fungal communities associated with Pinus thunbergii in the eastern coastal pine forests of Korea. Mycorrhiza. 20:39-49.

Richard F., Millot S., Gardes M., Selosse M.-A. 2005. Diversity and specificity of ectomycorrhizal fungi retrieved from an old-growth Mediterranean forest dominated by Quercus ilex. New Phytol. 166:1011-1023.

Selosse M.-A., Bauer R., Moyersoen B. 2002. Basal hymenomycetes belonging to the Sebacinaceae are ectomycorrhizal on temperate deciduous trees. New Phytol. 155:183-195.

Smith M.E., Douhan G.W., Rizzo D.M. 2007. Ectomycorrhizal community structure in a xeric Quercus woodland based on rDNA sequence analysis of sporocarps and pooled roots. New Phytol. 174:847-863.

Tedersoo L., Suvi T., Larsson E., Kõljalg U. 2006. Diversity and community structure of ectomycorrhizal fungi in a wooded meadow. Mycol. Res. 110:734-748.

Urban A., Puschenreiter M., Strauss J., Gorfer M. 2008. Diversity and structure of ectomycorrhizal and co-associated fungal communities in a serpentine soil. Mycorrhiza. 18:339-354.

Urban A., Weib M., Bauer R. 2003. Ectomycorrhizas involving sebacinoid mycobionts. Mycol. Res. 107:3-14.

Wei J., Agerer R. 2011. Two sebacinoid ectomycorrhizae on Chinese pine. Mycorrhiza. 21:105-115.

Weiss M., Selosse M.-A., Rexer K.-H., Urban A., Oberwinkler F. 2004. Sebacinales: a hitherto overlooked cosm of heterobasidiomycetes with a broad mycorrhizal potential. Mycol. Res. 108:1003-1010.

White T.J., Bruns T., Lee S., Taylor J. 1990. Amplification and direct sequencing of fungal ribosomal RNA genes for phylogenetics. PCR Protoc. Guide Methods Appl. 18:315-322. 


\title{
3 Dissecting the contributions of local ectomycorrhizal assemblages and microbial communities on nitrogen uptake of European beech (Fagus sylvatica)
}

\author{
Martin Leberecht ${ }^{\mathrm{A}}$, Michael Dannenmann ${ }^{\mathrm{B}, \mathrm{C}}$, Silvia Gschwendtner ${ }^{\mathrm{D}}$, Silvija Bilela ${ }^{\mathrm{C}}$, Rudolf \\ Meier $^{\mathrm{B}}$, Judy Simon ${ }^{\mathrm{C}}$, Heinz Rennenberg ${ }^{\mathrm{C}, \mathrm{E}}$, Michael Schloter ${ }^{\mathrm{D}}$, Andrea Polle ${ }^{\mathrm{A}}$

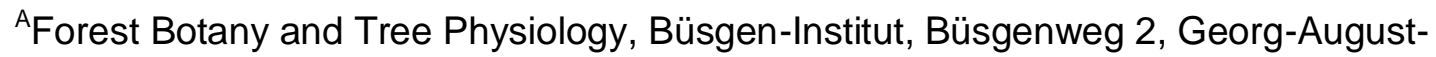 \\ University Göttingen, 37077 Göttingen, Germany \\ ${ }^{B}$ Institute of Meteorology and Climate Research, Atmospheric Environmental Research (IMK- \\ IFU), Karlsruhe Institute of Technology (KIT), Kreuzeckbahnstrasse 19, 82467 Garmisch- \\ Partenkirchen, Germany \\ ${ }^{C}$ Institute of Forest Science, Chair of Tree Physiology, University of Freiburg; Georges- \\ Koehler-Allee 53/54, 79110 Freiburg, Germany \\ ${ }^{D}$ Research Unit Environmental Genomics, Helmholtz Zentrum München, German Research \\ Center for Environmental Health (GmbH), Ingolstädter Landstraße 1, 85764 Neuherberg, \\ Germany \\ ${ }^{E}$ King Saud University, PO Box 2454, Riyadh 11451, Saudi Arabia
}

Submitted on 25.01.2014 to Applied and Environmental Microbiology

\subsection{Abstract}

The contributions of soil-mycorrhizosphere microbes, ectomycorhizal assemblages and tree origin on the nitrogen nutrition of beech (Fagus sylvatica) trees, a dominant forest species in Central Europe, were dissected. Young trees from natural regeneration of two genetically similar populations, one grown under dryer and warmer conditions (SW) and the other from cooler, moist climate (NE) were transplanted into a homogeneous substrate in the same environment and labelled with ${ }^{13} \mathrm{CO}_{2}$ and ${ }^{15} \mathrm{NH}_{4}{ }^{+}$to test the hypotheses that ectomycorrhizal assemblages from trees of $\mathrm{SW}$ and $\mathrm{NE}$ origin differ in fungal species composition and $\mathrm{N}$ acquisition and control $\mathrm{N}$ transfer to the trees, when competition by free microbes is low. Compared to systems with NE trees, those with SW trees exhibited the most rapid ${ }^{15} \mathrm{~N}$ accumulation, higher nitrification activities and stronger ${ }^{15} \mathrm{NO}_{3}{ }^{-}$accumulation in soil microbial biomass. ${ }^{15} \mathrm{~N}$ accumulation was similar in non-mycorrhizal root tips of SW and NE trees. A strong delay in ${ }^{15} \mathrm{~N}$ enrichment was found in the ectomycorrhizal assemblage of NE trees, which were dominated by basidiomycota, whereas more rapid and higher accumulation of ${ }^{15} \mathrm{~N}$ occurred in the acomycota-enriched assemblage of the SW trees. Because ${ }^{15} \mathrm{~N}$ accumulation in fine roots and transfer to leaves were delayed and lower in NE compared to $\mathrm{SW}$ trees, our data support that ectomycorrhizal assemblages control $\mathrm{N}$ transfer to their host and demonstrate that fungal assemblages from dry conditions are more efficient in $\mathrm{N}$ acquisition when environmental constraints are relieved. These findings highlight the importance of adapted ectomycorhizal communities for forest nutrition in a changing climate. 


\subsection{Introduction}

In Europe, forests are often confined to N-limited soils (Solberg et al. 2009), where ectomycorrhizal fungi (EMF) are important for tree nutrition (Read and Perez-Moreno 2003) The productivity of beech (Fagus sylvatica L.), a wide-spread, dominant forest species of great economic value and ecological importance in Central Europe (Ellenberg and Strutt 2009), is especially sensitive to $\mathrm{N}$ limitation under environmental stress (Rennenberg et al. 2009). Beech roots are colonized by a diverse flora of EMF taxa, which play critical roles in host nutrition. The composition of EMF assemblages is influenced by abiotic environmental factors such as drought as well as by host carbon allocation to roots (Shi et al. 2002; Buée et al. 2005; Druebert et al. 2009; Pena et al. 2010; Lang et al. 2011), but information whether different in situ EMF communities exhibit functional redundancy or diversity for host nutrition is sparse.

The control of EMF on $\mathrm{N}$ flux is complex because on the one hand decreased host carbon supply results in decreased $\mathrm{N}$ delivery by EMFs, whereas high $\mathrm{N}$ availability leads to enhanced C drain to the EMF (Corrêa et al. 2008; Albarracín et al. 2013; Näsholm et al. 2013). On the other hand, EMFs are instrumental to maintain host $N$ supply under drought stress and for the access to organic $\mathrm{N}$ from degrading leaf litter (Pena et al. 2013b; Pena and Polle 2014). Because the latter process is much slower than the capture of soluble $\mathrm{N}$ by soil borne microbes (Pena et al. 2013b) free-living microbes are strong competitors for this resource (Dannenmann et al. 2009; Kaiser et al. 2010).

In recent years, it has been realized that bulk soil, rhizosphere soil and the mycorrhizosphere of roots are colonized by distinct microbial communities and that the composition of the rootassociated fractions of both bacteria and fungi is influenced by the host genotype (Bradley et al. 2007; Bulgarelli et al. 2013; Danielsen et al. 2013). In rhizosphere soil, and also in the mycorrhizal mantle, a high density of bacteria is common (Mogge et al. 2000; Schloter et al. 2005). Besides other functions these bacteria catalyze the mineralization of organic matter and, thus, determine the nutrient supply of plants to a large extent. Because of their flexible genomes and short generation times bacterial communities have the potential to respond to environmental changes much faster than plants and EMF (Allen et al. 1995; Bossio and Scow 1995; Bossio et al. 1998; Pettersson and Bååth 2003). The activity and community composition of these microbes is strongly dependent on the quality and amount of rootderived carbohydrates (Dannenmann et al. 2009; Kaiser et al. 2010; Koranda et al. 2011; Rasche et al. 2011). Therefore, differences in belowground $C$ allocation patterns, which are a result of the plant developmental stage as well as biotic and abiotic stressors (Meier and Leuschner 2008), may also affect bacterial and EMF assemblages and functions and, thereby, impact $\mathrm{N}$ availability for forest trees.

In the present study, we relieved environmental constraints to unravel the influence of ectomycorrhizal assemblages in relation to bacterial activities for $\mathrm{N}$ uptake. We used natural beech regeneration of similar population genetics (Bilela et al. 2012) originating from well characterized beech forests with north-east (NE) and south-west exposure (SW) from a mountainous area in Southern Germany (Tuttlingen) (Fotelli et al. 2004; Geßler et al. 2005). At the SW site, the water availability is reduced to an extent similar to that predicted by climate models for the coming decades and the temperature is slightly increased compared with the NE site (Geßler et al. 2001; Holst et al. 2010). Soil type and N availability are similar in the NE and SW forests, but wood production of the beech trees at the SW site is significantly lower than that at the NE site (Geßler et al. 2001, 2005). It was, therefore, suspected that $\mathrm{N}$ utilization was impaired by physiological constraints in the SW compared 
with the NE trees. To dissect tree origin, bacterial and ectomycorrhizal contributions to tree $\mathrm{N}$ nutrition, we transplanted young beech trees into a fertilized peat-sand mixture and cultivated them under the same environmental conditions. We hypothesized that beech trees from SW exhibit lower $\mathrm{N}$ uptake than those from $\mathrm{NE}$, as observed previously under field conditions (Fotelli et al. 2004; Geßler et al. 2005) because of lower N acquisition and translocation by the EMF assemblages at roots of trees from SW than NE. We further hypothesized that these differences were related to lower belowground carbon allocation of trees from SW than of NE origin. To test these hypotheses, a 48h-pulse of ${ }^{13} \mathrm{CO}_{2}$ was applied and the soil system was repeatedly and homogenously labelled with ${ }^{15} \mathrm{NH}_{4}{ }^{+}$for seven days to investigate the accumulation kinetics of new $\mathrm{N}$ in microbial, ectomycorrhizal and plant tissues. In addition, EMF and bacterial community structures were determined and carbon allocation was traced by monitoring the $\delta^{13} \mathrm{C}$ signature in different plant tissues and soil respiration.

\subsection{Materials and Methods}

\subsubsection{Plant origin and plant cultivation}

Young beech (Fagus sylvatica) trees were collected in July 2010 in two 80 to 90-year-old beech dominated forests in the Swabian Jura near Tuttlingen (longitude $8^{\circ} 45^{\prime} \mathrm{E}$, latitude $47^{\circ} 59^{\prime} \mathrm{N}$, South West Germany) from the natural regeneration, which shows similar population genetics in these forests (Bilela et al. 2012). The forests are located on the North East (NE) and the South West (SW) exposure of a narrow valley (Krähenbachtal) with steep slopes $\left(23^{\circ}-30^{\circ}\right)$ (Dannenmann et al. 2007). The mean long-term annual regional air temperature $(1961-1990)$ is $6.6^{\circ} \mathrm{C}$ and the mean annual precipitation is $810 \mathrm{~mm}$ (Geßler et al. 2001). Because of the higher irradiance on the $S W$ site the soil temperature at $10 \mathrm{~cm}$ depth is $0.8^{\circ} \mathrm{C}$ higher and the soil water potential generally more negative than on the NE site (Keitel et al. 2003). On both sites, the soil type is a shallow Rendzic Leptosol (sceletic) (International Union of Soil Sciences Working Group WRB 2007) developed on limestone and marls of the Jurassic Malm formation (Dannenmann et al. 2006). Soil pH (water) is 5.7 in the organic layer and 7.5 at $0.6 \mathrm{~m}$ depth (Geßler et al. 2001).

Forty-five trees of stem heights of about $0.5 \mathrm{~m}$ were collected on each site. The trees were excavated with intact roots in their soil compartment and transported to a nursery (Forest Botanical Garden, University of Göttingen, longitude $9^{\circ} 57^{\prime} \mathrm{E}$, latitude $51^{\circ} 33^{\prime} \mathrm{N}$ ). The root systems were carefully cleaned under running water to remove adhering soil. The beech trees were planted separately in 5 I containers $(17 \times 17 \times 17 \mathrm{~cm})$ in a homogenous mixture of coarse sand (0.7 - $1.2 \mathrm{~mm}$ diameter, Melo Schwimmbadtechnik, Göttingen, Germany; 4.5 parts,), fine sand (0.4-0.8 mm diameter, Melo Schwimmbadtechnik; 4.5 parts) and peat (Torfwerk Zubrägel, Vechta, Germany; 1 part). The sand was washed with tap water before use to remove small particles. To match stand light conditions the trees were shaded with a $65 \%$ shading net (Herrmann Meyer KG, Rellingen, Germany) and placed outdoors. Each plant was watered daily with $50 \mathrm{ml}$ tap water. Not all trees survived the transplantation, leaving 32 trees per site for the further treatments. After one month, the beech trees were transferred into a greenhouse with $50 \%$ air humidity, an air temperature of $20{ }^{\circ} \mathrm{C}$ and long day conditions [16 h light achieved by additional irradiation with MT $400 \mathrm{DL} / \mathrm{BH}$ lamps (Eye Iwasaki Electric Co. Ltd., Tokyo, Japan), resulting in a photosynthetically active radiation of $150 \mu \mathrm{mol} \mathrm{m} \mathrm{m}^{-2} \mathrm{~s}^{-1}$ quantum flux density as determined by a photometer Li-185B equipped with a quantum sensor Li-190SB (LiCor INC., Lincoln, USA). This light intensity is typical for 
natural regeneration in beech forests (Ritter et al. 2005). Trees were cultured under these conditions for one month and watered daily with $50 \mathrm{ml}$ of a Hoagland-based nutrient solution (pH 5.7), which contained $0.4 \mathrm{mM} \mathrm{NH}_{4} \mathrm{Cl}$ as sole nitrogen source in addition to $0.05 \mathrm{mM}$ $\mathrm{NaSO}_{4}, 0.1 \mathrm{mM} \mathrm{K}_{2} \mathrm{SO}_{4}, 0.06 \mathrm{mM} \mathrm{MgSO}_{4}, 0.13 \mathrm{mM} \mathrm{CaSO}_{4}, 0.03 \mathrm{mM} \mathrm{KH}_{2} \mathrm{PO}_{4}, 0.005 \mathrm{mM}$ $\mathrm{MnSO}_{4}, 0.005 \mathrm{FeCl}_{3}, 5 \mu \mathrm{M} \mathrm{H}_{3} \mathrm{BO}_{3}, 0.13 \mu \mathrm{M} \mathrm{NaMoO}_{4}, 0.18 \mu \mathrm{M} \mathrm{ZnSO}_{4}$ and $0.16 \mu \mathrm{M} \mathrm{CuSO}_{4}$ (adapted after (Dyckmans 2000)). Two days before experimental labeling, root collar diameters at soil level, and heights of all trees were measured.

\subsection{2 ${ }^{13} \mathrm{C}$ and ${ }^{15} \mathrm{~N}$ labeling}

The beech-soil systems were labeled with ${ }^{13} \mathrm{CO}_{2}$ and ${ }^{15} \mathrm{NH}_{4} \mathrm{Cl} .{ }^{13} \mathrm{CO}_{2}\left(1.5 \%{ }^{13} \mathrm{C}\right.$, Cambridge Isotope Laboratories, Andover, USA) fumigation started on the 4.10 .12 at 8 am and ended after $48 \mathrm{~h}$. During this time a $\mathrm{CO}_{2}$ concentration of $1091 \pm 193 \mathrm{ppm}$ was recorded (UNOR $610 \mathrm{CO}_{2}$ analyzer, Maihak, Hamburg, Germany). For homogenous distribution, the ${ }^{13} \mathrm{C}$ labeled air in the greenhouse was intensively mixed by a fan (SF16R, SMC, Hong Kong, China).

${ }^{15} \mathrm{NH}_{4} \mathrm{Cl}\left(0.4 \mathrm{mmol}, 99 \%{ }^{15} \mathrm{~N}\right.$, Cambridge Isotope Laboratories, Andover, USA) was applied daily on seven consecutive days starting on 4.10 .12 at 8 am. To achieve homogenous ${ }^{15} \mathrm{~N}$ soil labeling, the nutrient solution was injected by syringes $(1.5 \mathrm{ml})$ applying a total of $50.7 \mathrm{ml}$ by 39 injections of $1.3 \mathrm{ml}$ of ${ }^{15} \mathrm{~N}$-solution at depths of 0,5 and $10 \mathrm{~cm}$ per container. This treatment corresponds to a daily amount of $0.337 \mathrm{mg}{ }^{15} \mathrm{~N}$ in excess of the natural abundance. Eight trees per site were maintained in another greenhouse without ${ }^{13} \mathrm{C}$ and ${ }^{15} \mathrm{~N}$ labeling as non-labeled controls.

\subsubsection{Soil respiration}

On day 2, 3, 4, 6 and 8 after the start of the experimental labeling, soil respiration and soil ${ }^{13} \mathrm{CO}_{2}$ evolution were determined using a static chamber approach (Wu et al. 2010). At $11 \mathrm{am}$, a chamber (area: $120 \mathrm{~cm}^{2}$, height $10 \mathrm{~cm}$ ) was gently inserted $1 \mathrm{~cm}$ into the soil at 3 randomly chosen containers of the NE and the SW treatment, respectively. Two minutes, 15 min and $30 \mathrm{~min}$ after chamber placement, a gas sample of $20 \mathrm{ml}$ was taken via gastight syringe sampling through a septum. The air sample was immediately transferred in a septum-capped pre-evacuated gastight $5 \mathrm{ml}$ vial. For this purpose, the entire sample volume of $20 \mathrm{ml}$ was flushed from the syringe through the vial by using a second cannula in the septum cap, which was removed at the end of the flushing procedure, leaving an overpressure of $25 \%$ in the sample vial. Within four days after sampling, sampled air in vials was analyzed for the $\mathrm{CO}_{2}$ concentration and the $\delta^{13} \mathrm{C}$ signature of $\mathrm{CO}_{2}$ using GasBench II coupled to the isotope ratio mass spectrometer Delta Plus XP (Thermo Fisher Scientific, Bremen, Germany). We used a PoraBOND Q column (Agilent, Böblingen, Germany) at 33 ${ }^{\circ} \mathrm{C}$ and a sample loop with $250 \mu \mathrm{L}$ volume. Samples were calibrated using three standard gasses (325 ppm CO $\mathrm{CO}_{2}$ with $\delta^{13} \mathrm{C}=-8.296 \%$; $340 \mathrm{ppm} \mathrm{CO} \mathrm{CO}_{2}$ with $\delta^{13} \mathrm{C}=-29.3 \%$; and $550 \mathrm{ppm}$ $\mathrm{CO}_{2}$ with $\delta^{13} \mathrm{C}=-14.677 \%$ in synthetic air) (Air Liquide, Kornwestheim, Germany). Soil respiration was calculated from the increase in $\mathrm{CO}_{2}$ concentrations during the $30 \mathrm{~min}$ sampling interval (Wu et al. 2010)). Due to the low soil respiration rates, the $\mathrm{CO}_{2}$ concentration increase was linear over the 30 minutes period. The increase in $\mathrm{CO}_{2}$ concentration over time had to match a quality criterion of $\mathrm{R}^{2}>0.9$; otherwise the respective soil respiration flux was discarded (in one case). 


\subsubsection{Harvest}

Eight plant-soil containers per site were harvested 1, 3 and 7 days after the start of ${ }^{15} \mathrm{~N}$ labeling. Eight control plant-soil systems per site were harvested at $d=0$. Leaves and aboveground woody parts (branches and stem) were separated after harvest and weighed immediately. Five leaves were separately weighed, scanned with a CCD camera KP-C551 (Hitachi, Tokyo, Japan) and analyzed with ImageJ 1.47v (National Institute of Health, Bethesda, USA). Whole plant leaf area was calculated as: area of leaves/mass of leaves ${ }^{\times}$ mass of all leaves.

The roots were then carefully washed under running tap water. Coarse (> $2 \mathrm{~mm}$ diameter) and fine roots $(<2 \mathrm{~mm}$ diameter) were separated and weighed. One $\mathrm{g}$ of fine roots from unlabeled beech seedlings was shock-frozen in liquid $\mathrm{N}_{2}$ for amino acid determination (see below). Fine root samples were wrapped in moist paper towels and stored in darkness in plastic bags at $4^{\circ} \mathrm{C}$. Dry mass of fine roots was determined after ectomycorrhizal analysis (see below). All remaining plant parts were weighed immediately after harvest, dried and weighed after one week at $60^{\circ} \mathrm{C}$.

The entire soil of each planting container was mixed and a representative sample of $500 \mathrm{~g}$ per container was used for further analyses. In addition to bulk soil, rhizosphere soil (RS, defined as soil attached to roots after slight shaking) and rhizosphere root complex (RRC, containing fine roots with tightly adhering soil, which could not be removed) were sampled as described previously (Gschwendtner et al. 2010). RS and RRC samples were immediately frozen on dry ice and stored at $-80^{\circ} \mathrm{C}$.

\subsubsection{Soil analyses}

Immediately after harvest $300 \mathrm{~g}$ of representative bulk soil was weighed and dried at $105^{\circ} \mathrm{C}$ for 24 hours. Soil water content (SWC [\%]) was determined as:

$S W C=\frac{s f w-s d w}{s d w} \times 100$

with sdw being soil dry weight (g) and sfw soil fresh weight (g).

Further fresh soil aliquots of $60 \mathrm{~g}$ were either directly extracted with $0.5 \mathrm{M} \mathrm{K}_{2} \mathrm{SO}_{4}$ solution at a soil:solution ratio of 1:2 or after 24 hours of fumigation with chloroform (Dannenmann et al. 2009). All extracts were filtrated with $0.45 \mu \mathrm{m}$ syringe filters (Schleicher \& Schuell, Dassel, Germany) and immediately frozen. Aliquots of the soil extracts were used for spectrophotometric determination of ammonium $\left(\mathrm{NH}_{4}{ }^{+}\right)$and nitrate $\left(\mathrm{NO}_{3}{ }^{-}\right)$concentrations by a commercial laboratory (Dr. Janssen $\mathrm{GmbH}$, Gillersheim, Germany) and for total dissolved $\mathrm{N}(\mathrm{TN})$ and total dissolved organic $\mathrm{C}$ (DOC) by auto-analyzers as described by (Dannenmann et al. 2009). Dissolved organic N (DON) was calculated as the difference between $\mathrm{TN}$ in extracts and inorganic $\mathrm{N}$ in extracts. Microbial biomass $\mathrm{C}$ and $\mathrm{N}$ was calculated from the difference in TN and DOC between extracts from fumigated and unfumigated soil, without application of correction factors (Dannenmann et al. 2009). In addition to $\mathrm{N}$ concentrations of the soil microbial biomass, $\mathrm{NH}_{4}{ }^{+}, \mathrm{NO}_{3}{ }^{-}$and $\mathrm{DON}$ pools, their respective ${ }^{15} \mathrm{~N}$ signatures were determined. The approach was based on diffusion of $\mathrm{NH}_{4}{ }^{+}$via $\mathrm{pH}$ increase on acid filter traps prepared for isotope ratio mass spectrometry, after sequential conversion of all target- $\mathrm{N}$ compounds in soil extracts to $\mathrm{NH}_{4}{ }^{+}$as described in detail in earlier studies (Guo et al. 2013b). Determination of ${ }^{15} \mathrm{~N}$ enrichment in total extractable $\mathrm{N}$ of both unfumigated control soils and fumigated soils was based on alkaline persulfate oxidation of all $\mathrm{N}$ compounds to $\mathrm{NO}_{3}{ }^{-}$and subsequent $\mathrm{NO}_{3}{ }^{-}$reduction to $\mathrm{NH}_{4}{ }^{+}$as 
described by (Wu et al. 2011). Subsequent diffusion of $\mathrm{NH}_{3}$ on acid filter traps enabled the quantification of ${ }^{15} \mathrm{~N}$ enrichment in microbial biomass as calculated from the difference in $\mathrm{N}$ concentration and ${ }^{15} \mathrm{~N}$ enrichment in TN between unfumigated control soils and fumigated soils (Guo et al. 2013b). No correction factors were applied in order to obtain estimates of ${ }^{15} \mathrm{~N}$ uptake into active microbial biomass (Perakis and Hedin 2001).

\subsubsection{Identification of ectomycorrhizal fungi}

The washed fine roots were spread under a dissecting microscope (205 FA, Leica, Wetzlar, Germany) and remaining soil particles were removed using fine forceps. Randomly chosen 2 to $3 \mathrm{~cm}$ long root fragments were used for mycorrhizal analysis. Four hundred mycorrhizal root tips per plant were counted and classified as mycorrhizal, non mycorrhizal or dead root tips. If not enough root material was available to reach 400 mycorrhizal root tips, all available root tips were counted. Aliquots of mycorrhizal, non-mycorrhizal and dead root tips were collected of each plant and freeze-dried for ${ }^{15} \mathrm{~N}$ and ${ }^{13} \mathrm{C}$ measurements.

The mycorrhizal root tips were assigned to morphotypes, based on morphological features like color, mantle structure, type of ramification, shape of unramified ends, emanating hyphae and rhizomorphes (Agerer 1987). All morphotypes were photographed with a DFC420 C camera (Leica, Wetzlar, Germany) at 10 - 40 x magnification and aliquots were stored at $20^{\circ} \mathrm{C}$ for species identification by internal transcribed spacer (ITS) sequencing.

The molecular identification of ectomycorrhizal fungi was conducted as previously described in (Druebert et al. 2009; Lang et al. 2011)). DNA of about 20 root tips assigned to one morphotype was extracted (innuPREP DNA Kit, Analytik Jena, Jena, Germany) as recommended by the manufacturer. The ITS region was amplified using the PCR primers ITS1F and ITS4 (Eurofins MWG Operon, Ebersberg, Germany) (White et al. 1990; Gardes and Bruns 1993). The obtained PCR products were purified with sodium acetate.

Sequencing was performed by the Sequencing service of the Büsgen-Institute, Department Forest Genetics and Forest Tree Breeding of the Georg August University Göttingen using the Big Dye Terminator 3.1 Cycles Sequencing Kit (Applied Biosystems, Foster City, USA). The sequences were assembled with StadenPackage V4.10 and compared with UNITE (http://unite.ut.ee) and NCBI (http://www.ncbi.nlm.nih.gov) databases. Species names were accepted when $97 \%$ identities and a score over 800 bits were achieved. All sequences have been deposited in NCBI Genbank with GenBank accession numbers KF498567-KF498582.

\subsection{7 $\underline{\mathrm{C} \text { and } \mathrm{N} \text { measurements and isotope analysis of plant tissues and mycorrhizal root }}$ tips}

Dry plant tissues were ground with a ball mill (Retsch, Düsseldorf, Germany). Mycorrhizal, non-mycorrhizal and dead root tips were processed without milling. Samples were weighed (Supermicro S4; Sartorius, Göttingen, Germany) into $5 \times 9 \mathrm{~mm}$ tin capsules (IVA Analysetechnik, Meerbusch, Germany). For leaves $0.8 \mathrm{mg}$, for stem $5.0 \mathrm{mg}$, for coarse roots $3.0 \mathrm{mg}$, for fine roots $2.0 \mathrm{mg}$ and for mycorrhizal, non-mycorrhizal and dead root tips $0.5-3$ mg of tissue were used. ${ }^{14} \mathrm{~N},{ }^{15} \mathrm{~N},{ }^{12} \mathrm{C}$, and ${ }^{13} \mathrm{C}$ isotope analyses were conducted the service unit KOSI (Kompetenzzentrum für Stabile Isotope, University Göttingen, Germany) on a Delta Plus mass spectrometer (Finnigan MAT, Bremen, Germany; Interface: Conflo III, Finnigan MAT, Bremen, Germany; elemental analyzer: NA2500, CE Instruments, Rodano, Milano, Italy). 
APE $\left({ }^{15} \mathrm{~N}\right.$ atom-\% excess) was determined as:

${ }_{15} \mathrm{NAPE}=$ atom $-\%$ sample - atom-\%natural abundance

with atom $-\%=\frac{{ }^{15} \mathrm{~N}}{{ }^{14} \mathrm{~N}+{ }^{15} \mathrm{~N}} \times 100$.

$\delta^{13} \mathrm{C}$ values were determined as:

$\delta^{13} C=\left(\frac{{ }^{13} C_{\text {Sample }}}{\frac{{ }^{12} C_{\text {Sample }}}{{ }^{13} C_{V P D B}}}\right) \times 1000$

with $C_{V P D B}=$ Vienna Pee Dee Belemnite Standard.

APE $\left({ }^{13} \mathrm{C}\right.$ atom-\% excess) was determined as:

${ }^{13} \mathrm{C} \mathrm{APE}=$ atom- $\%$ sample - atom-\% $\%$ natural abundance

with atom $-\%=\frac{{ }^{13} C}{{ }^{12} C+{ }^{13} C} \times 100$.

\subsubsection{Amino acid determination}

Amino compounds were extracted from $96 \mathrm{~h}$-freeze-dried fine root samples according to the method of (Winter et al. 1992). Amino compounds were determined in $50 \mu \mathrm{l}$ samples using a Waters Acquity UPLC-System (Waters Corp., Milford, MA, USA) with a modified standard protocol (using an AccQTag ${ }^{\mathrm{TM}}$ Ultra column $2.1 \times 100 \mathrm{~mm}, 1.7 \mu \mathrm{l}, 0.7 \mathrm{ml} \mathrm{min}^{-1}$ flow, column temperature $61^{\circ} \mathrm{C}$ ) (Luo et al. 2009). Standard H (\#NCI0180, Pierce Biotechnology, Inc., Rockford, IL, USA) was used as the analytical standard.

\subsubsection{Extraction of bacterial DNA}

DNA was extracted from $0.4 \mathrm{~g}$ of rhizosphere soil and $0.1-0.2 \mathrm{~g}$ of rhizosphere root complex, respectively, using the NucleoSpin Soil Kit (Macherey Nagel, Düren, Germany) and the Precellys 24 Instrument (Bertin Technologies, Montigny-le-Bretonneux, France). Quantity and quality of the extracted DNA were checked with a Nanodrop spectrophotometer (PeqLab, Erlangen, Germany) and by gel electrophoresis (Gschwendtner et al. 2010). The extracts were stored at $-20^{\circ} \mathrm{C}$ until use.

\subsubsection{Total bacterial community structure}

To assess bacterial community structure, amplicons of the 16S rRNA gene were analyzed by terminal restriction fragment length polymorphism (TRFLP). The universal primers $27 \mathrm{f}$ (5'AGAGTTTGATCCTGGCTCAG-3', 6-Fam-labelled) and 1401r (5'-

CGGTGTGTACAAGACCC-3') were used to amplify $1.4 \mathrm{~kb}$ fragments of the $16 \mathrm{~S}$ rRNA gene (Schreiner et al. 2010). Each PCR assay (total volume $50 \mu \mathrm{l}$ ) contained $60 \mathrm{ng}$ of template DNA, 0.3\% bovine serum albumin (BSA) (Sigma Aldrich, Taufkirchen, Germany), 5\% dimethyl sulfoxid (DMSO) (Sigma Aldrich), $200 \mu \mathrm{M}$ desoxynucleotide (dNTP) (Fermentas, St. 
Leon Rot, Germany), $2.5 \mathrm{mM} \mathrm{MgCl}$, $2.5 \cup$ Taq Polymerase (Life Technologies, Darmstadt, Germany), 1x Taq buffer (Life Technologies) and 10 pmol of each primer. PCR was performed in a T3 thermocycler (Biometra, Göttingen, Germany) using the following conditions: $10 \mathrm{~min}$ at $94^{\circ} \mathrm{C}$ for initial denaturation, followed by 30 cycles of $1 \mathrm{~min}$ at $94^{\circ} \mathrm{C}, 1$ min at $57^{\circ} \mathrm{C}$ and $1.5 \mathrm{~min}$ at $72^{\circ} \mathrm{C}$ and a final extension step for 10 min at $72^{\circ} \mathrm{C}$. PCR products were analyzed by electrophoresis on $1.5 \%$ agarose gels and purified using the QIAquick PCR Purification Kit (Qiagen, Hilden, Germany). The enzymatic restriction was performed as described previously (Schreiner et al. 2010), using $200 \mathrm{ng}$ of labelled PCR product, $5 \mathrm{U}$ of Mspl (Fermentas) and $1 \mathrm{x}$ reaction buffer (total volume $25 \mu \mathrm{l}$ ). The reaction mixtures were incubated for 6 hours at $37^{\circ} \mathrm{C}$, followed by 20 min at $65^{\circ} \mathrm{C}$ for enzyme inactivation.

Afterwards, the samples were purified using the MinElute Reaction Cleanup Kit (Qiagen). The TRFLP profiles were generated using an ABI Prism 3730 Genetic Analyzer. Sizes and relative abundances of terminal restriction fragments (TRFs) were analyzed using GeneMapper software and T-REX software (http://trex.biohpc.org/) with a binning range of 2 bp. Only TRFs with a signal above $1 \%$ of the sum of all peak heights were included in the analysis.

\subsubsection{Abundance of mineralizers, nitrogen fixers, ammonia oxidizers and denitrifiers} Quantitative real-time PCR (RT-PCR) was performed using an ABI 7300 Cycler (Applied Biosystems, Foster City, USA) to assess the abundance of selected marker genes which were used as proxy for microbes involved in different steps of the nitrogen cycle with the following assay reagents: DMSO and BSA (Sigma Aldrich), primers listed in Table 3.1 (Metabion, Germany) and 2x Power SYBR Green master mix (Life Technologies, Darmstadt, Germany). The respective $25 \mu \mathrm{l}$ reaction mixtures for quantification of the genes [ $\mathrm{nifH}$ (nitrogenase), amoA AOA (ammonia monooxygenase in ammonia oxidizing archaea), amoA AOB (ammonia monooxygenase in ammonia oxidizing bacteria), narG (nitrat reductase), nirS (nitrite reductase), nirk (nitrite reductase), nosZ (nitrous-oxide reductase), chiA (chitinase), apr (protease)] were composed as follows: $12.5 \mu$ I SYBR Green master mix, 5 pmol of each primer (for apr gene: $10 \mathrm{pmol}$ of each primer), $0.5 \mu \mathrm{l} 3 \% \mathrm{BSA}$ and $2 \mu \mathrm{l}$ DNA template. For the amplification of narG, nirK, and nirS genes, $0.5 \mu \mathrm{l}$ DMSO was added. Primer sources and measuring conditions are summarized in Table 3.1 .

For quantification, serial dilutions $\left(10^{1}\right.$ to $10^{6}$ gene copies $\left.\mu \mathrm{l}^{-1}\right)$ of plasmid DNA containing PCR products of the respective genes listed in Table 3.1 were used to calculate standard curves. The PCR detection limit was assessed to 10 gene copies according to manufacturer's instruction. To avoid PCR inhibition, the optimal dilution for each amplification assay was determined in advance by dilution series of randomly chosen DNA extracts. The RT-PCR assays were performed in 96-well plates (Life Technologies) for all target genes. All PCR runs started with a hot start at $95^{\circ} \mathrm{C}$ for 10 minutes. To confirm the specificity of the SYBR Green-quantified amplicons, a melting curve analysis and a 1.5\% agarose gel were performed after each PCR run. The amplification efficiency was calculated as Eff $=\left[10^{(-1 / s / o p e)}\right.$ 1] and resulted in the following average efficiencies (standard deviation less than $5 \%$ of mean): nifH, 87\%, amoA AOA, 92\%, amoA AOB, 86\%, narG, 92\%, nirk, 94\%, nirS, 93\%, nosZ, $86 \%$, chiA, $92 \%$, apr, $94 \%$. 
Table 3.1: Primer sets and thermal profiles used for the absolute quantification of the respective genes nifH: nitrogenase, amoA AOA: ammonia monooxygenase in ammonia oxidizing archaea, amoA AOB: ammonia monooxygenase in ammonia oxidizing bacteria, narG: nitrate reductase, nirS: nitrite reductase, nirK: nitrite reductase, nosZ: nitrous-oxide reductase, chiA: chitinase, apr: protease.

\begin{tabular}{|c|c|c|c|c|}
\hline $\begin{array}{l}\text { Target } \\
\text { gene }\end{array}$ & Primer & References & Thermal profile & $\begin{array}{l}\text { No. of } \\
\text { cycles }\end{array}$ \\
\hline nifH & nifH-f, nifH-r & Rösch et al. 2002 & $95^{\circ} \mathrm{C}-45 \mathrm{~s} / 55^{\circ} \mathrm{C}-45 \mathrm{~s} / 72^{\circ} \mathrm{C}-45 \mathrm{~s}$ & 40 \\
\hline amoA AOA & $\begin{array}{l}\text { amo19F, } \\
\text { CrenamoA16r48x }\end{array}$ & $\begin{array}{l}\text { Leininger et al. 2006; } \\
\text { Schauss et al. } 2009\end{array}$ & $94^{\circ} \mathrm{C}-45 \mathrm{~s} / 55^{\circ} \mathrm{C}-45 \mathrm{~s} / 72^{\circ} \mathrm{C}-45 \mathrm{~s}$ & 40 \\
\hline amoA AOB & $\begin{array}{l}\text { amoA1F, } \\
\text { amoA2R }\end{array}$ & Rotthauwe et al. 1997 & $94^{\circ} \mathrm{C}-45 \mathrm{~s} / 59^{\circ} \mathrm{C}-45 \mathrm{~s} / 72^{\circ} \mathrm{C}-45 \mathrm{~s}$ & 40 \\
\hline \multirow[t]{2}{*}{ narG } & narG-f, narG-r & Bru et al. 2007 & $95^{\circ} \mathrm{C}-15 \mathrm{~s} / 63-58^{\circ} \mathrm{C}-30 \mathrm{~s} / 72^{\circ} \mathrm{C}-30 \mathrm{~s}$ & 5 * \\
\hline & & & $95^{\circ} \mathrm{C}-15 \mathrm{~s} / 58^{\circ} \mathrm{C}-30 \mathrm{~s} / 72^{\circ} \mathrm{C}-30 \mathrm{~s}$ & 40 \\
\hline nirs & cd3aF, R3cd & $\begin{array}{l}\text { Michotey et al. 2000; } \\
\text { Throbäck et al. } 2004\end{array}$ & $95^{\circ} \mathrm{C}-45 \mathrm{~s} / 57^{\circ} \mathrm{C}-45 \mathrm{~s} / 72^{\circ} \mathrm{C}-45 \mathrm{~s}$ & 40 \\
\hline \multirow[t]{2}{*}{ nirk } & nirK876, nirK5R & $\begin{array}{l}\text { Braker et al. 1998; } \\
\text { Henry et al. } 2004\end{array}$ & $95^{\circ} \mathrm{C}-15 \mathrm{~s} / 63-58^{\circ} \mathrm{C}-30 \mathrm{~s} / 72^{\circ} \mathrm{C}-30 \mathrm{~s}$ & 5 * \\
\hline & & & $95^{\circ} \mathrm{C}-15 \mathrm{~s} / 58^{\circ} \mathrm{C}-30 \mathrm{~s} / 72^{\circ} \mathrm{C}-30 \mathrm{~s}$ & 40 \\
\hline \multirow[t]{2}{*}{ nosZ } & nosZ2F, nosZ2R & Henry et al. 2006 & $95^{\circ} \mathrm{C}-15 \mathrm{~s} / 65-60^{\circ} \mathrm{C}-30 \mathrm{~s} / 72^{\circ} \mathrm{C}-30 \mathrm{~s}$ & 5 * \\
\hline & & & $95^{\circ} \mathrm{C}-15 \mathrm{~s} / 60^{\circ} \mathrm{C}-30 \mathrm{~s} / 72^{\circ} \mathrm{C}-30 \mathrm{~s}$ & 40 \\
\hline chiA & chiF2, chiR & Xiao et al. 2005 & $95^{\circ} \mathrm{C}-30 \mathrm{~s} / 60^{\circ} \mathrm{C}-30 \mathrm{~s} / 72^{\circ} \mathrm{C}-60 \mathrm{~s}$ & 40 \\
\hline Apr & FPapr1, RPapr2 & Bach et al. 2001 & $95^{\circ} \mathrm{C}-20 \mathrm{~s} / 53^{\circ} \mathrm{C}-30 \mathrm{~s} / 72^{\circ} \mathrm{C}-60 \mathrm{~s}$ & 40 \\
\hline
\end{tabular}

* Touchdown: $-1^{\circ} \mathrm{C}$ per cycle

\subsubsection{Data analysis}

Data were analyzed with Origin Pro 8.5 (OriginLab Corporation, Northampton, USA) using Students' $t$ tests for normal distributed data sets. Normal distribution was tested with the Kolmogorov-Smirnov test. If data did not show normal distribution, they were log-transformed to meet the requirement of normality. General Linear Models (GLM) were applied to investigate the main factors (time, site) and their interactions (Statgraphics Centurion XVI Version 16.2.03 (Statpoint Technologies, Warrenton, USA). In tables and figures data are shown as means \pm standard error (SE). Differences between means were considered significant at $P \leq 0.05$. Diversity indices and their comparisons were calculated with PAST 2.17c using a bootstrap of 200 (Hammer et al. 2001). Similarity indices were calculated as generalized Morisita-Horn index $\mathrm{C} \_\mathrm{qN}$ by comparing $\mathrm{N}$ communities on species information shared by at most q communities using the procedure developed by (Chao et al. 2008) and implemented in the program SPADE by Chao and Shen (2010) (http://chao.stat.nthu.edu.tw). EMF species abundances, and microbial abundances for RRC and RS from the TRFLP analysis, normalized to 10000 , were used as input parameters and run with a bootstrap value of 200. Rarefaction curves were calculated using EstimateS Win 7.5.3

(http://purl.oclc.org/estimates). 


\subsection{Results}

Characteristics of the plant-soil system of beech trees originating from two contrasting field sites after cultivation under common environmental conditions

Young beech trees from NE and SW were transplanted into a peat-sand-mixture, grown for two months in the same environment and then labeled in a greenhouse for $48 \mathrm{~h}$ with ${ }^{13} \mathrm{CO}_{2}$ and for one week daily with ${ }^{15} \mathrm{~N}$ (Fig. 3.1). During the labeling period $\mathrm{SWC}, \mathrm{NH}_{4}{ }^{+}, \mathrm{NO}_{3}{ }^{-}, \mathrm{DOC}$ and DON soil concentrations showed no important temporal fluctuations and, therefore, mean values for the containers with beeches from NE or SW are shown (Table 3.2).

Microbial biomass in bulk soil, determined as microbial $\mathrm{N}$ and microbial $\mathrm{C}$, neither differed, but soil respiration, which is the result of microbial and root respiration, was higher in the NE than in the SW containers (Table 3.2). However, the $\delta^{13} \mathrm{CO}_{2}$ signature of soil respiration was not significantly different between NE and SE beech containers, suggesting similar belowground utilization of newly acquired photosynthetates (Fig. 3.1).

Although the beech trees were selected on the basis of similar stem heights and diameters, differences in whole-plant biomass were observed: NE beech trees exhibited significantly greater whole-plant leaf area $(+23 \%)$ and root biomass $(+27 \%)$ than those from SW (Table 3.3). The differences in belowground biomass resulted in a significantly higher root-to-shoot ratio of NE compared to SW beech trees (Table 3.3).

The natural $\delta^{13} \mathrm{C}$ signature of leaves is an integrative indicator for water availability (Keitel et al. 2006). Because no significant differences of the $\delta^{13} \mathrm{C}$ signatures were detected at the start of the labeling ( $t=0$, Table 3.4), we have no evidence that the differences in plant biomass were the result of acute drought periods during their growth under field conditions. ${ }^{13} \mathrm{C}$ pulse labeling did not indicate differences in photosynthetic performance because the leaves from $\mathrm{NE}$ and $\mathrm{SW}$ beeches showed the same changes in response to the ${ }^{13} \mathrm{CO}_{2}$ labeling pulse at $\mathrm{t}$ $=8 \mathrm{~d}$ (Table 3.4). However, carbon allocation of recent photosynthetate to fine roots was stronger in SW than in NE trees, evident from a higher $\delta^{13} \mathrm{C}$ signature in $\mathrm{SW}$ than in NE fine roots at $8 d$ (Table 3.4).

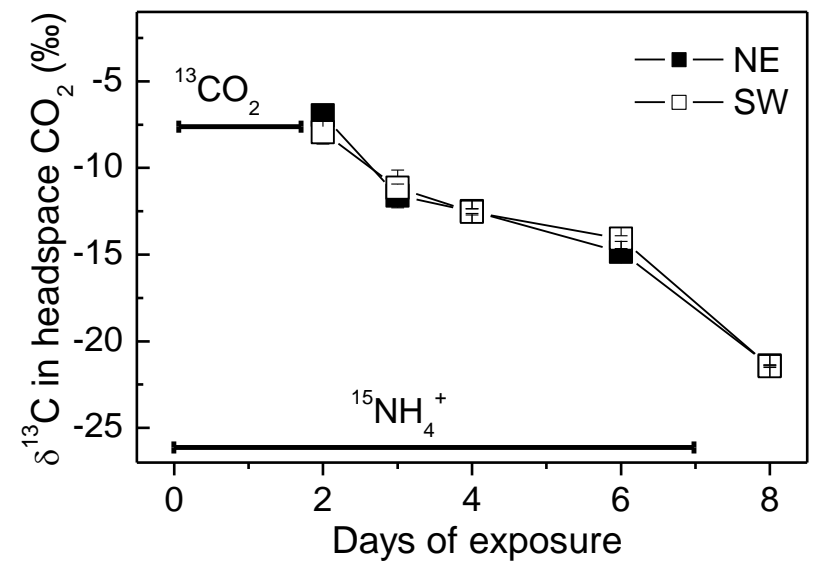

Figure 3.1: $\delta^{13} \mathrm{C}$ signature of $\mathrm{CO}_{2}$ in static chamber headspace after labeling for $48 \mathrm{~h}$ with ${ }^{13} \mathrm{CO}_{2}$. The duration of the ${ }^{13} \mathrm{C}$ and ${ }^{15} \mathrm{~N}$ labeling is indicated by bars. Data are means \pm SE gained during static chamber soil respiration measurements in containers with beech trees from the SW (open) and NE (closed symbols) stands. Error bars are smaller than the symbols. 
Table 3.2: Characteristics of the soil parameters two months after transplantation of young beech trees (Fagus sylvatica) originating from beech forests on slopes with south west (SW) and north east (NE) exposure in a low mountain range in southern Germany (Jura). Natural beech regeneration was transplanted into a sand-peat mixture, grown with regular fertilizer application for two months under identical conditions and labeled for one week with ${ }^{15} \mathrm{NH}_{4}{ }^{+}$. Measurements of soil parameters were taken regularly during the experimental week. Data show means $\pm \mathrm{SE}$ of all sampling dates.

Significant differences between soils of beech from different sites are indicated by P-values $<0.05$ (bold letters). The abbreviations refer to SDW: soil dry weight, DON: dissolved organic nitrogen, DOC: dissolved organic carbon, MBN nitrogen in microbial biomass, MBC: carbon in microbial biomass.

\begin{tabular}{|c|c|c|c|}
\hline & $\mathrm{NE}$ & SW & $P$ \\
\hline Soil water content [\% SDW] & $7.95 \pm 0.24$ & $8.51 \pm 0.25$ & 0.11 \\
\hline Ammonium [mg N kg$\left.{ }^{-1} \mathrm{SDW}\right]$ & $0.51 \pm 0.07$ & $0.44 \pm 0.06$ & 0.44 \\
\hline Nitrate [mg N kg ${ }^{-1}$ SDW] & $0.22 \pm 0.03$ & $0.21 \pm 0.03$ & 0.71 \\
\hline $\mathrm{DON}$ [mg N kg$\left.{ }^{-1} \mathrm{SDW}\right]$ & $2.17 \pm 0.18$ & $2.1 \pm 0.13$ & 0.76 \\
\hline $\mathrm{DOC}[\mathrm{mg} \mathrm{N}]$ & $18.97 \pm 1.34$ & $16.8 \pm 1$ & 0.2 \\
\hline MBN [mg N kg$\left.{ }^{-1} \mathrm{SDW}\right]$ & $3.42 \pm 0.22$ & $3.28 \pm 0.16$ & 0.61 \\
\hline $\mathrm{MBC}\left[\mathrm{mg} \mathrm{C} \mathrm{kg}{ }^{-1} \mathrm{SDW}\right]$ & $11.2 \pm 1.13$ & $11.5 \pm 0.59$ & 0.81 \\
\hline Soil respiration $\left[\mathrm{mg} \mathrm{CO}_{2}-\mathrm{C} \mathrm{m}^{-2} \mathrm{~h}^{-1}\right.$ ] & $11.53 \pm 1.08$ & $8.48 \pm 0.22$ & 0.03 \\
\hline
\end{tabular}

Table 3.3: Characteristics of young beech trees (Fagus sylvatica) originating from beech forests on slopes with south west (SW) and north east (NE) exposure in a low mountain range in southern Germany (Jura). Trees from the natural regeneration were cultured for two months in a sand-peat mixture, fertilized regularly and labeled with ${ }^{15} \mathrm{~N}$ for one week. Trees were harvested regularly within the experimental week $(n=8$ per site and sampling date). Data show means \pm SE of all sampling dates per site, for amino acids only at day 8. P-values of General Linear Models for the factor "Site" are shown, because the factor "Time" had no significant effect $\left(P_{\text {time }}>0.05\right)$. P-values $<0.05$ are highlighted in bold letters.

\begin{tabular}{llll}
\hline & NE & SW & $P_{\text {site }}$ \\
\hline Stem height [cm] & $53.84 \pm 1.03$ & $53.19 \pm 1.15$ & 0.66 \\
Stem diameter [mm] & $5.63 \pm 0.1$ & $5.45 \pm 0.1$ & 0.2 \\
Leaf area [cm²] & $454 \pm 19$ & $369 \pm 18$ & $<0.001$ \\
Whole-plant dry mass [g plant-1] & $11.58 \pm 0.53$ & $9.48 \pm 0.38$ & 0.01 \\
Aboveground dry mass [g plant-1] & $6.03 \pm 0.32$ & $5.43 \pm 0.23$ & 0.14 \\
Belowground dry mass [g plant-1] & $5.54 \pm 0.25$ & $4.35 \pm 0.2$ & $<0.001$ \\
Root/Shoot & $0.94 \pm 0.04$ & $0.82 \pm 0.04$ & 0.02 \\
Amino acids [ $\mu$ mol g-1 dry weight] & $5.06 \pm 0.44$ & $5.79 \pm 0.38$ & 0.25 \\
Mycorrhizal root tips [\%] & $38.08 \pm 2.38$ & $30.36 \pm 2.55$ & 0.03 \\
Dry root tips [\%] & $6.57 \pm 0.93$ & $12.87 \pm 1.94$ & $<0.001$ \\
Non mycorrhizal root tips [\%] & $55.34 \pm 2.51$ & $56.77 \pm 2.48$ & 0.69 \\
\hline
\end{tabular}


Table 3.4: $\delta^{13} \mathrm{C}$ signatures in plant tissues and ectomycorrhizas of young beech trees (Fagus sylvatica) originating from beech forests on slopes with south west (SW) and north east (NE) exposure in a low mountain range in southern Germany (Jura). Trees from the natural regeneration were cultured for two months in a sand-peat mixture, fertilized regularly and exposed to ${ }^{13} \mathrm{CO}_{2}$ for two days.

$\delta^{13} \mathrm{C}$ was analyzed at day 0 and day 8 after the start of labeling $(n=8$ per site and sampling date).

Data show means \pm SE. P-values for a multivariate ANOVA with site and time as fixed factors and for a one way ANOVA for the comparisons of tissues are shown in columns and rows, respectively. Different letters indicate significant differences $(P<0.05)$ of the tissues calculated post hoc with the HSD test. P-values $<0.05$ are highlighted in bold letters. FR = fine roots, EMF = ectomycorrhizal fungi, $\mathrm{NM}=$ non-mycorrhizal roots

\begin{tabular}{lllllll}
\hline & \multicolumn{5}{c}{$\boldsymbol{\delta}^{\mathbf{1 3}} \mathbf{C}(\%)$} \\
Site & Time & Leaf & FR & EMF & NM & $P_{\text {(tissue) }}$ \\
\hline NE & 0 & $-31.3 \pm 0.2 \mathrm{a}$ & $-30.0 \pm 0.3 \mathrm{ab}$ & $-29.2 \pm 0.5 \mathrm{~b}$ & $-30.7 \pm 0.6 \mathrm{a}$ & $\mathbf{0 . 0 2 1}$ \\
$\mathrm{NE}$ & 8 & $-30.3 \pm 0.3 \mathrm{a}$ & $-28.2 \pm 0.3 \mathrm{a}$ & $-27.0 \pm 0.7 \mathrm{a}$ & $-17.4 \pm 1.9 \mathrm{~b}$ & $<\mathbf{0 . 0 0 1}$ \\
$\mathrm{SW}$ & 0 & $-32.0 \pm 0.3 \mathrm{a}$ & $-28.7 \pm 0.6 \mathrm{~b}$ & $-29.9 \pm 0.3 \mathrm{~b}$ & $-30.0 \pm 0.6 \mathrm{~b}$ & $\mathbf{0 . 0 0 2}$ \\
$\mathrm{SW}$ & 8 & $-30.4 \pm 0.2 \mathrm{a}$ & $-27.3 \pm 0.5 \mathrm{~b}$ & $-27.0 \pm 0.9 \mathrm{~b}$ & $-16.3 \pm 1.4 \mathrm{c}$ & $<\mathbf{0 . 0 0 1}$ \\
$\mathrm{P}_{\text {Site }}$ & & 0.123 & $\mathbf{0 . 0 2 3}$ & 0.571 & 0.482 & \\
$\mathrm{P}_{\text {Time }}$ & $<0.001$ & $\mathbf{0 . 0 0 2}$ & $\mathbf{0 . 0 0 1}$ & $<\mathbf{0 . 0 0 1}$ & \\
$\mathrm{I}_{\text {(Site xTime) }}$ & & 0.403 & 0.734 & 0.607 & 0.858 & \\
\hline
\end{tabular}

Visual analysis of the root tips revealed an almost two-fold larger fraction of apparently dead root tips on SW than on NE beech trees (Table 3.3). The root tips had a distorted and shrunken appearance (Winkler et al. 2010) and exhibited only low ${ }^{15} \mathrm{~N}$ enrichment $(0.11 \pm$ 0.02 APE compared with $4.3 \pm 0.6$ APE of vital root tips) underpinning their reduced physiological activity. Enhanced root mortality at SW was also typical for the young trees at their field sites (fraction of dead root tips at NE: $11 \pm 2 \%$ and $S W=35 \pm 7 \%, P_{\text {site }}=0.004$ ). After cultivation in the soil-peat mixture, the beech roots exhibited a relatively high percentage (55\%) of non-mycorrhizal roots (Table 3.3), whereas non-mycorrhizal roots were barely found on young trees directly after excavation from their native soils (fraction of EMFcolonized root tips at NE and SW: $99.3 \pm 0.4 \%, P_{\text {site }}=0.859$ ). Therefore, the non-mycorrhizal roots must have developed during the culture in the sand-peat medium with regular fertilization. A fraction of about 30 to $38 \%$ of the total root tips were vital EMF-colonized root tips under the experimental conditions applied (Table 3.3).

Mycorrhizal and bacterial communities associated with roots of NE and SW beech trees We identified a total of 41 different EMF based on morphological features (Table 3.5), half of which colonized about $80 \%$ to $90 \%$ of the mycorrhizal root tips and were identified by ITS sequencing (Table 3.5). Cenococcum geophilum was the most abundant species on both root tips of SW and NE trees, but occurred twice as frequent on roots of beeches from SW than on those from NE (Fig. 3.2, Table 3.5). Two further ascomycetes (Peziza sp.) were also more abundant on roots of SW compared to NE trees (Fig. 3.2). On roots of NE trees basidomycetes were generally more abundant than on SW trees, in particular Lactarius rubrocinctus and two other Lactarius species ( $\mathrm{La} \mathrm{1,} \mathrm{La} \mathrm{2)} \mathrm{as} \mathrm{well} \mathrm{as} \mathrm{Laccaria} \mathrm{amethystina}$ (La) and a Russula species (Ru1, Fig. 3.2). Species rarefaction curves indicated higher species richness of EMF at SW than at NE trees (Fig. 3.3, Table 3.6), but the Shannon- 
Wiener index and Evenness of the EMF assemblages at SW were lower than at NE (Table 3.6) because of the dominance of $C$. geophilum (Table 3.5).

Analysis of the mycorrhizosphere-root microbial community (RRC) of NE and SW trees revealed no significant differences for species richness, Shannon-Wiener index and Evenness, respectively (Table 3.6). The rhizosphere soil microbes (RS) showed a moderate increase in species richness at roots of NE compared to SW beech trees, but no differences for the Shannon Wiener index or Evenness (Table 3.6). The Morisita Horn index, which compares the similarities of species assemblages based on their richness and abundances, was higher than 0.9, demonstrating that the microbes in the RRC fraction from NE and SW were highly similar ( 1 = identical); the same was true for RS microbes of NE and SW roots (Fig. 3.4). A lower Morisita Horn index of the EM than of the microbes supports the assumption that the assemblages from NE and SW trees were more dissimilar among each other than the free microbial communities (Fig. 3.4). However, there were differences in microbial communities between RRC and RS, which were stronger for the SW than for the NE trees (Fig. 3.4).

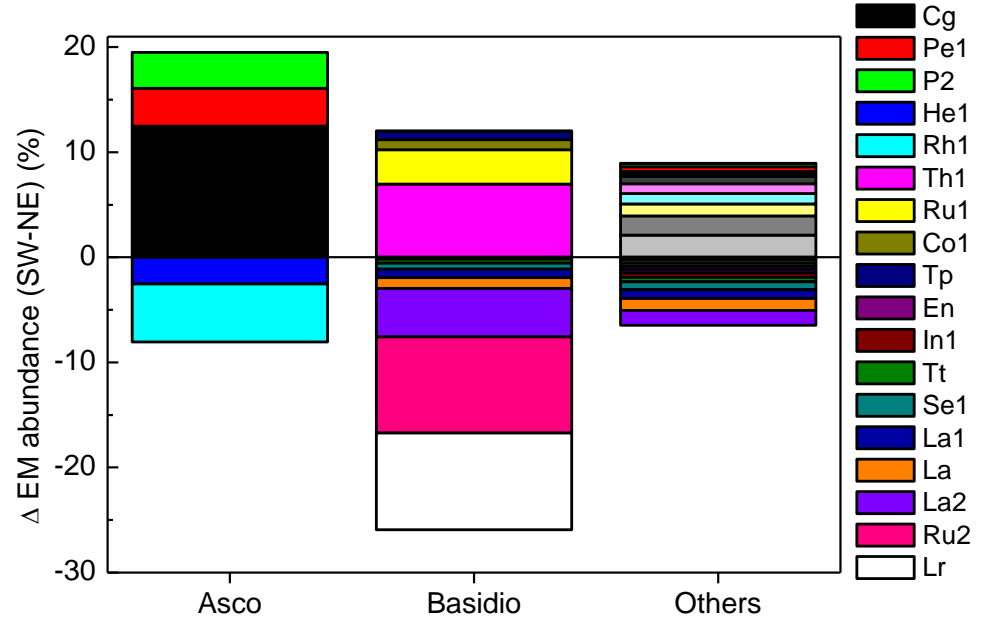

Figure 3.2: Differences in the abundance of ectomycorrhizal species on beech roots from the SW and the NE site. The fungal morphotypes were recorded on a total of 13093 and 10898 root tips from NE and SW trees, respectively. The data were normalized to 10.000 root tips. Differences were calculated as: relative abundance of species $_{(i)}$ at SW - relative abundance of species ${ }_{(i)}$ at NE. Data were stacked according to ascomycota (Asco), basidiomycota (Basidio) and others. Others are rare morphotypes for which species information was not available. Abbreviations refer to Cenococcum geophilum $(\mathrm{Cg})$, Peziza sp 1 and 2 (Pe1, Pe 2), uncultured Helotiales (He1), uncultured Rhizoscyphus (Rh1), uncultured Thelephoraceae (Th1), Russula sp. 1 and 2 (Ru1, Ru2), Cortinarius sp. (Co1), Tomentella punicea (Tp), Entoloma nidorosum (En), Inocybe sp. (In1), Thelephora terrestris (Tt), Sebacina sp (Se1), Lactarius morphotype 1 and 2 (La1, La2), Laccaria amethystina (La), Lactarius rubrocinctus (Lr). Further information is given in Table 3.5. 

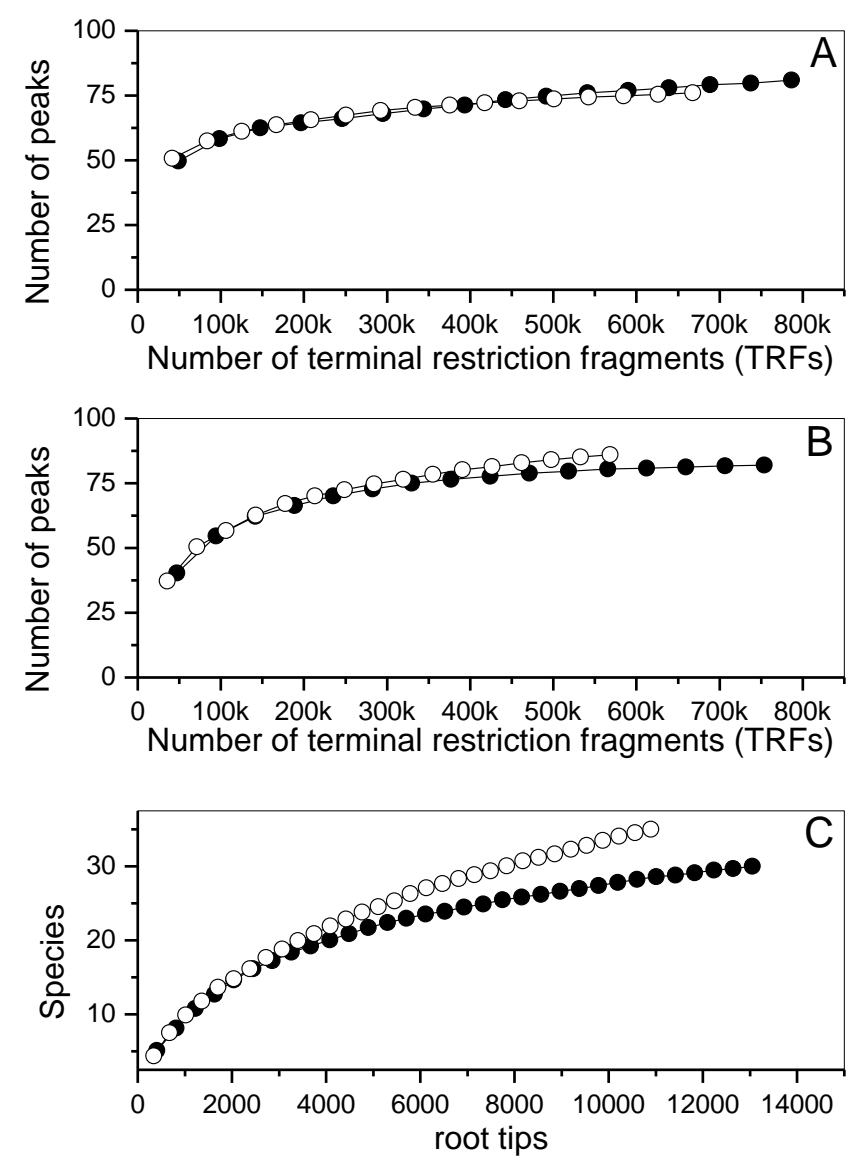

Figure 3.3: Saturation curves of rhizosphere soil (A), mycorhizosphere-root (B) associated bacteria and mycorrhizal (C) communities. Data of NE trees are shown in closed circles, data of SW trees in open circles. Species data all sampling dates were combined ( $n=16$ per site for microbial communities, $\mathrm{n}=32$ per site for mycorrhizal communities).

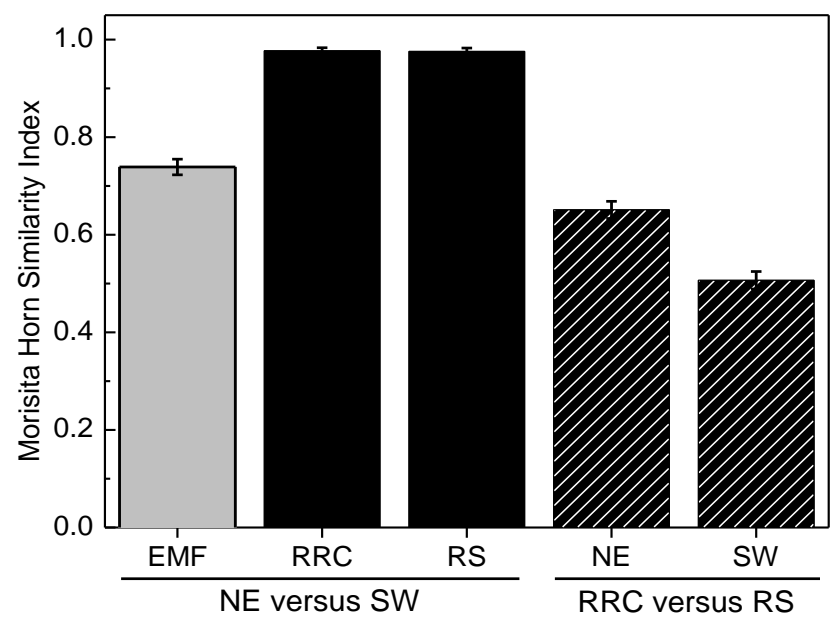

Figure 3.4: Morisita Horn Similarity Indices for pairwise comparisons of the microbial communities. The analyses are based on species richness and abundance data normalized to 10.000 individuals. Error bars indicate the calculated $95-\%$ confidence intervals. 
Table 3.5: Abundances (\%) and species identities of ectomycorrhizal fungi on roots of Fagus sylvatica trees natural regeneration originating from beech forests on a northeast (NE) and south west (SW) slope on the Swabian Jura. A: Ascomycota, B: Basidiomycota. MT: number of morphotype(s), name: a species names was assigned when the identity of the best match in NCBI or UNITE was $\geq 97 \%$. Accession number indicates the accession number under which the species were deposited in NCBI.

\begin{tabular}{|c|c|c|c|c|c|c|c|}
\hline MT & $\begin{array}{l}\mathrm{NE} \\
(\%)\end{array}$ & $\begin{array}{l}\text { SW } \\
(\%)\end{array}$ & Division & Name (Accession Number) & Best match (Acc. Num.) & Score & $\begin{array}{l}\text { Identities } \\
(\%)\end{array}$ \\
\hline 1 & 13.90 & 26.38 & A & Cenococcum sp. (KF498567) & Uncultured Cenococcum (EU668240) & 872 & 99 \\
\hline 9 & 11.35 & 2.14 & B & Lactarius rubrocinctus (KF498568) & Lactarius rubrocinctus (JF908273) & 1447 & 100 \\
\hline 11 & 11.03 & 14.29 & B & Russula sp. 1 (KF498569) & Russula subfoetens (UDB016206) & 1128 & 96 \\
\hline 22 & 9.57 & 0.43 & B & Russula sp. 2 (KF498570) & $\begin{array}{l}\text { Russula romellii (UDB011365) } \\
\text { Uncultured Rhizoscyphus }\end{array}$ & 1096 & 96 \\
\hline 14 & 6.27 & 0.76 & A & Uncultured Rhizoscyphus (KF498571) & (HQ212326) & 1003 & 98 \\
\hline 24 & 5.77 & 4.96 & B & Lactarius sp. (KF498572) & Lactarius pterosporus (JQ446153) & 563 & 98 \\
\hline 16 & 5.73 & 4.73 & B & Laccaria amethystina (KF498573) & Laccaria amethystina (UDB000039) & 1298 & 99 \\
\hline 21 & 5.35 & 2.80 & A & Uncultured Helotiales (KF498574) & Uncultured Helotiales (GU174410) & 999 & 98 \\
\hline 15 & 5.01 & 0.38 & B & Lactarius sp.* & & & \\
\hline 8 & 4.13 & 3.73 & $\mathrm{~B}$ & Thelephora terrestris (KF498575) & Thelephora terrestris (UDB003346) & 1239 & 99 \\
\hline 7 & 3.54 & 10.52 & $\mathrm{~B}$ & $\begin{array}{l}\text { Uncultured Thelephoraceae } \\
\text { (KF498576) }\end{array}$ & $\begin{array}{l}\text { Uncultured Thelephoraceae } \\
\text { (AJ893330) }\end{array}$ & 910 & 96 \\
\hline 30 & 3.29 & 3.12 & B & Inocybe sp. (KF498577) & Uncultured Inocybe (HE687062) & 831 & 94 \\
\hline 25 & 2.83 & 2.26 & B & Sebacina sp. (KF498578) & Uncultured Sebacina (JN701901) & 1275 & 100 \\
\hline 26 & 1.68 & 0.54 & & & & & \\
\hline 13 & 1.51 & 5.11 & A & Peziza sp. (KF498579) & Uncultured Peziza (FR852092) & 860 & 97 \\
\hline 34 & 1.41 & 0.00 & & & & & \\
\hline 39 & 1.30 & 0.56 & & & & & \\
\hline 3 & 1.15 & 0.31 & & & & & \\
\hline 20 & 0.71 & 0.30 & & & & & \\
\hline 5 & 0.62 & 1.40 & B & Tomentella punicea (KF498580) & Tomentella punicea (UDB000950) & 1082 & 99 \\
\hline 2 & 0.58 & 0.27 & & & & & \\
\hline 17 & 0.53 & 0.40 & & & & & \\
\hline 28 & 0.44 & 0.00 & & & & & \\
\hline 18 & 0.38 & 0.43 & B & Entoloma nidorosum (KF498581) & Entoloma nidorosum (UDB008239) & 1616 & 99 \\
\hline 40 & 0.34 & 0.00 & & & & & \\
\hline 4 & 0.32 & 2.15 & & & & & \\
\hline 36 & 0.31 & 0.00 & & & & & \\
\hline 33 & 0.29 & 0.18 & & & & & \\
\hline 29 & 0.29 & 0.00 & & & & & \\
\hline 12 & 0.19 & 0.21 & & & & & \\
\hline 32 & 0.18 & 0.65 & & & & & \\
\hline 6 & 0.00 & 3.41 & A & Uncultured Pezizales (KF498582) & Uncultured Pezizales (EU668248) & 896 & 98 \\
\hline 37 & 0.00 & 2.12 & & & & & \\
\hline 23 & 0.00 & 1.12 & & & & & \\
\hline 35 & 0.00 & 1.00 & & & & & \\
\hline 19 & 0.00 & 0.96 & B & Cortinarius sp.* & & & \\
\hline 27 & 0.00 & 0.92 & & & & & \\
\hline 10 & 0.00 & 0.71 & & & & & \\
\hline 38 & 0.00 & 0.46 & & & & & \\
\hline 31 & 0.00 & 0.29 & & & & & \\
\hline
\end{tabular}

${ }^{*}$ Identification by morphotyping after (Agerer 1987-2006). 
Table 3.6: Diversity indices for ectomycorrhizas, mycorrhizosphere-root associated (RRC) and rhizosphere soil bacteria (RS) of young beech trees (Fagus sylvatica) originating from beech forests on slopes with south west (SW) and north east (NE) exposure in a low mountain range in southern Germany (Jura). Natural beech regeneration was transplanted into a sand-peat mixture and grown with regular fertilizer application for two months under identical conditions and harvested after 0, 1, 4 and 8 days (ectomycorrhiza) or after 0 and 8 days after the start of labeling $(n=8$ per site and sampling date). Data of all sampling dates were pooled to reach species saturation. $P_{(\text {perm })}$ values were calculated by permutation with 1000 random matrices. Data for RS and RRC were calculated after normalization of the peak abundances identified by RFLP analyses to 10000 arbitrary units and those for ectomycorrhizas based on species and morphotype data normalized to 10.000 root tips per site.

\begin{tabular}{|c|c|c|c|c|c|c|c|c|c|}
\hline \multirow{2}{*}{$\begin{array}{l}\text { Diversity } \\
\text { index }\end{array}$} & \multicolumn{3}{|c|}{ Ectomycorrhiza } & \multicolumn{3}{|c|}{ RRC } & \multicolumn{3}{|l|}{ RS } \\
\hline & $\mathrm{NE}$ & SW & $P_{(\text {perm })}$ & $\mathrm{NE}$ & SW & $P_{(\text {perm })}$ & NE & SW & $P_{(\text {perm })}$ \\
\hline $\begin{array}{l}\text { Species } \\
\text { richness }\end{array}$ & 32 & 36 & 0.001 & 86 & 91 & 0.261 & 85 & 89 & 0.027 \\
\hline $\begin{array}{l}\text { Shannon } \\
\text { Wiener } \\
\text { index }\end{array}$ & 2.92 & 2.8 & 0.001 & 3 & 3.09 & 0.18 & 3.28 & 3.28 & 0.362 \\
\hline Evenness & 0.58 & 0.46 & 0.001 & 0.23 & 0.24 & 0.748 & 0.29 & 0.34 & 0.115 \\
\hline
\end{tabular}

Table 3.7: ${ }^{15} \mathrm{~N}$ and $\mathrm{N}$ content and mean concentrations in young beech trees (Fagus sylvatica) originating from beech forests on slopes with south west (SW) and north east (NE) exposure in a low mountain range in southern Germany (Jura), ${ }^{15} \mathrm{~N}$ and $\mathrm{N}$ content and mean concentrations in soil microbial biomass and the ${ }^{15} \mathrm{~N}$ recovery rates of trees, microbes and total plant soil systems. Natural beech regeneration was transplanted into a sand-peat mixture, grown with regular fertilizer application for two months under identical conditions and labeled for one week with ${ }^{15} \mathrm{~N} .{ }^{15} \mathrm{~N}$ excess was determined at day $8(n=8)$ in all plant tissues, soil microbes, soil $\mathrm{NH}_{4}, \mathrm{NO}_{3}$ and $\mathrm{DON}$ after subtraction of the natural ${ }^{15} \mathrm{~N}$ abundance. ${ }^{15} \mathrm{~N}$ and $\mathrm{N}$ concentrations are weighed means for all plant tissues and compartments of the plant soil system, respectively.

\begin{tabular}{llllll}
\hline Site & ${ }^{15} \mathrm{~N}$ APE & $\mathrm{N}$ & ${ }^{15} \mathrm{~N}$ APE & $\mathrm{N}$ & ${ }^{15} \mathrm{~N} \mathrm{APE}_{\text {microbes }}$ \\
\hline & $\left(\mu \mathrm{g} \mathrm{plant}^{-1}\right)$ & $\left(\mathrm{mg} \mathrm{plant}^{-1}\right)$ & $\left(\mu \mathrm{g} \mathrm{g}^{-1} \mathrm{dw}\right)$ & $\left(\mathrm{mg} \mathrm{g}^{-1} \mathrm{dw}\right)$ & $\left(\mathrm{ng} \mathrm{g}^{-1} \mathrm{sdw}\right)$ \\
$\mathrm{NE}$ & $262 \pm 131$ & $83 \pm 13$ & $23.7 \pm 4.9$ & $7.21 \pm 0.57$ & $71.9 \pm 29.1$ \\
$\mathrm{SW}$ & $337 \pm 135$ & $72 \pm 10$ & $31.9 \pm 4.6$ & $6.76 \pm 0.33$ & $87.9 \pm 59.0$ \\
$\mathrm{P}$ & 0.28 & 0.066 & 0.245 & 0.077 & 0.511 \\
& & & & & \\
\hline
\end{tabular}

\begin{tabular}{|c|c|c|c|}
\hline & \multicolumn{2}{|c|}{ Recovery (\% ${ }^{15} \mathrm{~N}$ APE) } & \multirow[b]{2}{*}{ (total system) } \\
\hline & (trees) & (microbes) & \\
\hline $\mathrm{NE}$ & $11.1 \pm 5.6$ & $17.7 \pm 7.6$ & $43.0 \pm 13.7$ \\
\hline SW & $14.3 \pm 5.7$ & $23.8 \pm 11.9$ & $55.3 \pm 17.9$ \\
\hline P & 0.277 & 0.283 & 0.149 \\
\hline
\end{tabular}


Beeches from SW and NE show differences in ${ }^{15} \mathrm{~N}$-accumulation related to differences in microbial-mycorrhizal N processing

During the $7 \mathrm{~d}$ labeling period with ${ }^{15} \mathrm{NH}_{4}{ }^{+}$, a significant time-dependent accumulation of ${ }^{15} \mathrm{~N}$ was found in all soil and plant fractions analyzed $\left(\mathrm{P}_{\text {time }}\right.$ in the GLM for all data in Fig. $3.5<$ 0.001 ). Overall, we recovered $49 \%$ and $59 \%$ of the applied ${ }^{15} \mathrm{~N}$ in the NE and SW plant-soil systems, respectively (Table 3.7 ).

As expected, the strongest ${ }^{15} \mathrm{~N}$ enrichment appeared in $\mathrm{NH}_{4}{ }^{+}$, which was used for labelling of the soil solution (Fig. 3.5a), but $\mathrm{NO}_{3}{ }^{-}$and microbial biomass also showed strong ${ }^{15} \mathrm{~N}$ enrichments indicating microbial uptake and nitrification (Fig. $3.5 \mathrm{~b}, \mathrm{~d}$ ). In contrast, the ${ }^{15} \mathrm{~N}$ enrichment in DON was about an order of magnitude lower than in $\mathrm{NO}_{3}{ }^{-}$or soil microbes (Fig. 3.5c). Notably, the ${ }^{15} \mathrm{~N}$ enrichment was higher in inorganic $\mathrm{N}$ compounds and in microbial $\mathrm{N}$ in the containers with beeches from SW than in those with beeches from NE (Fig. 3.5a, b, d). The greatest difference was found for $\mathrm{NO}_{3}^{-}$, where the ${ }^{15} \mathrm{~N}$ enrichment was about twice higher in containers with SW trees than in those with NE trees after one week of labeling (Fig. 3.5b).

We also found stronger ${ }^{15} \mathrm{~N}$ enrichment in fine roots and leaves of the SW than of the NE beech trees (Fig. 3.5e, f). Because $\mathrm{N}$ acquired by the plant is taken up by the active zone of the non-mycorrhizal root tips or the ectomycorrhizas, we measured the ${ }^{15} \mathrm{~N}$ enrichments in these tissues (Fig. $3.5 \mathrm{~g}, \mathrm{~h}$ ). Interestingly, the ${ }^{15} \mathrm{~N}$ enrichment in non-mycorrhizal root tips was very strong and exceeded that of ${ }^{15} \mathrm{~N}$ in the microbial fraction $(P=0.004)$, but without any significant differences between the NE and SW trees (Fig. 3.5g). The non-mycorrhizal root tips of both, NE and SW trees, also showed strong ${ }^{13} \mathrm{C}$ enrichment at $8 \mathrm{~d}$, suggesting a high $\mathrm{C}$ demand of these tissues (Table 3.4).

In contrast to non-mycorrhizal roots tips, the ectomycorrhizal root tips showed striking, significant differences in ${ }^{15} \mathrm{~N}$ enrichment between SW and NE trees. The ectomycorrhizas of SW trees accumulated ${ }^{15} \mathrm{~N}$ slightly delayed compared to microbial ${ }^{15} \mathrm{~N}$, but eventually reached a similar enrichment, whereas ${ }^{15} \mathrm{~N}$ enrichment in NE ectomycorrhizas was much slower and lagged behind ${ }^{15} \mathrm{~N}$ uptake into microbes (Fig $3.5 \mathrm{~d}, \mathrm{~h}$ ). To find out whether the differences in $\mathrm{N}$ uptake were related to differences in carbon allocation to the ectomycorrhizas of SW and NE beech trees, respectively, the ${ }^{13} \mathrm{C}$ signatures of the colonized root tips were measured, but significant differences were not observed at d8 (Table 3.4). The $\delta^{13} \mathrm{C}$ signatures of the ectomycorrhizas were similar to those of fine roots (Table 3.4).

The differences in $\mathrm{N}$ processing and plant $\mathrm{N}$ uptake were also linked to the relative abundance of microbes involved in $\mathrm{N}$ turnover in the RRC. Here, overall higher gene copy numbers for $\mathrm{N}$-mineralizers, $\mathrm{N}$-fixers, nitrifiers, and denitrifiers were found indicating a generally faster $\mathrm{N}$-turnover in the RRC of SW than of NE trees $(P=0.013)$. Most pronounced differences were observed in the organic nitrogen cycle for microbes involved in protein and chitin degradation (based on increased abundance of the chiA and apr gene). In the inorganic nitrogen cycle mainly ammonia oxidizing bacteria and nitrite oxidizers harboring nirS took benefit from the high loads of inorganic N in the RRC of SW trees (Fig. 3.6a). In the $\mathrm{RS}$ fraction no significant differences in the abundance of microbes involved in the different transformation steps of the nitrogen cycle were found between NE and SW trees (Fig. 3.6b). To find out whether the observed differences in $\mathrm{N}$ cycling affected whole-plant $\mathrm{N}$ uptake, the ${ }^{15} \mathrm{~N}$ content was determined in all plant fractions at d8. However, the total amounts of ${ }^{15} \mathrm{~N}$ taken up did not differ between SW and NE trees (Table 3.7), probably because of the short duration of this study and also because of the slightly higher biomass of the NE than of the 
SW beeches. Significant differences at $\mathrm{P}<0.05$ were neither found for the $\mathrm{N}$ content nor the $\mathrm{N}$ concentrations based on whole plant biomass (Table 3.7). The majority of the newly taken up $\mathrm{N}$ was localized in fine roots $(88 \pm 2 \%$ ) regardless the origin of the trees (data not shown). The total amino acid concentrations in the fine roots, which play a role in the regulation of plant $\mathrm{N}$ uptake (Geßler et al. 2004b), neither varied significantly between NE and SW trees (Table 3.3).
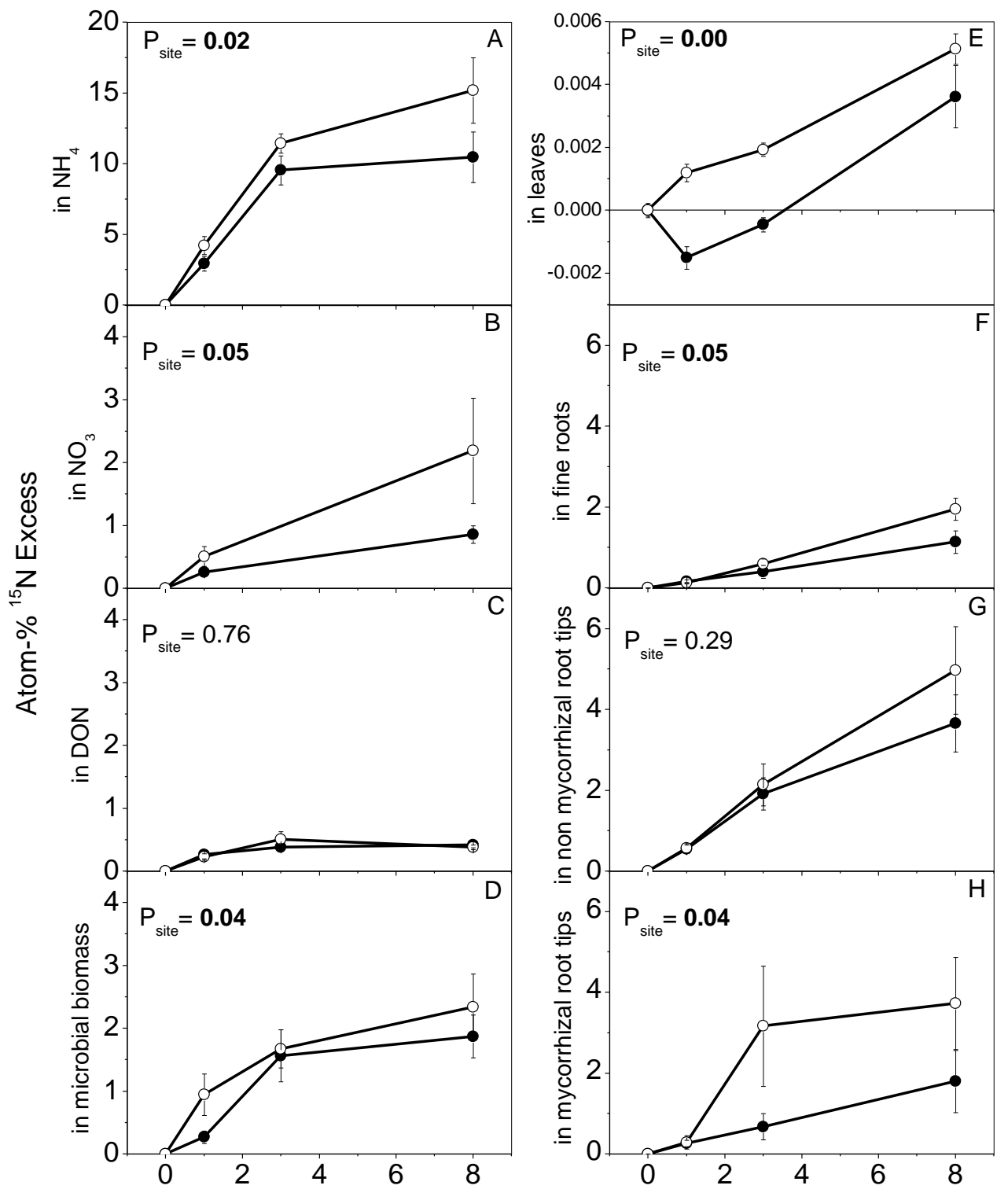

Figure $3.5:{ }^{15} \mathrm{~N}$ accumulation kinetics in soil $\mathrm{N}$ compounds, microbial biomass, ectomycorrhizas, and plant tissues. Natural beech regeneration was transplanted into a sand-peat mixture, grown with regular fertilizer application for two months under identical conditions and labeled for $8 \mathrm{~d}$ with ${ }^{15} \mathrm{NH}_{4}{ }^{+}$. Data are means ( $n=8, \pm S E$ ) in atom-\% excess (APE) for ammonia (a), nitrate (b), DON (dissolved organic nitrogen, $c$ ) and microbial biomass (d) in soil as well as for leaves (e), fine roots (f), non mycorrhizal root tips (g), and mycorrhizal root tips (h). Note different scales. NE: closed circles, SW: open cicles, Data were compared by General Linear Models with "Time" and "Site" as fixed factors. Pvalues for the factor "Site" are indicated in the figure. All P values for the factor "Time" were significant at $\mathrm{P}<0.05$. 

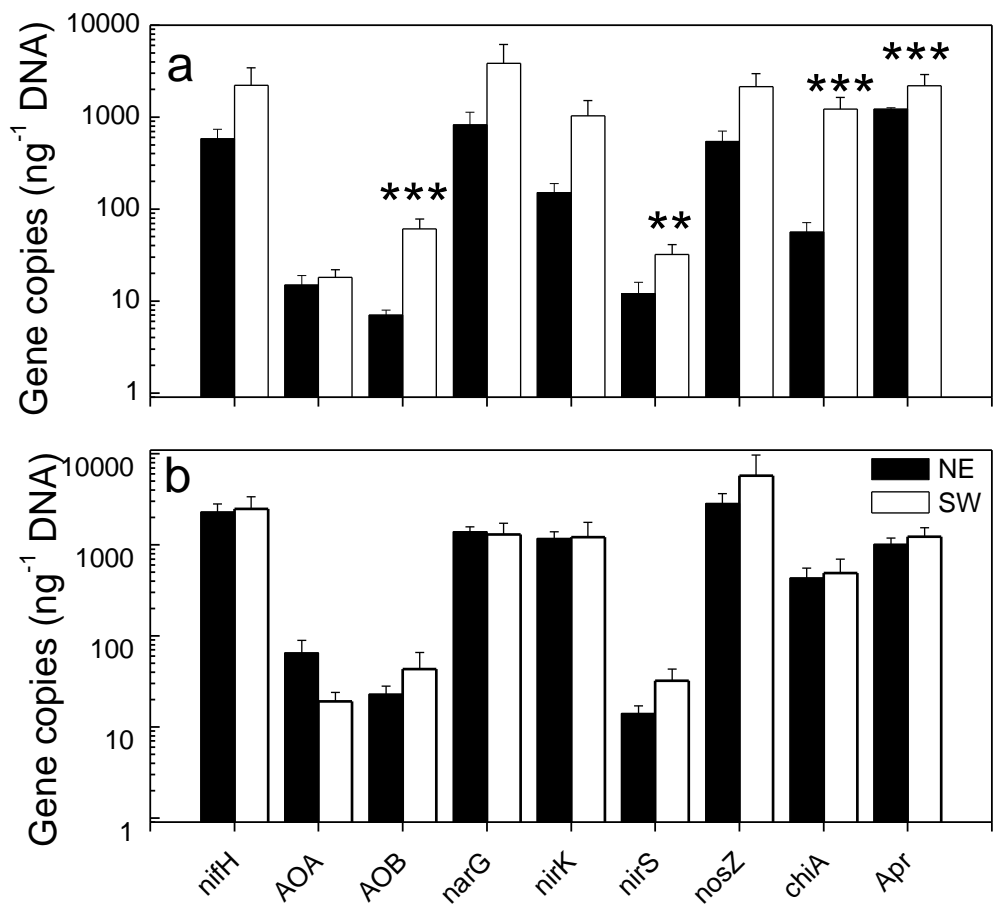

Figure 3.6: Relative abundances of genes coding for important steps of the nitrogen cycle (gene copies $\mathrm{ng}^{-1} \mathrm{DNA}$ ) in rhizosphere root complex (a) and rhizosphere soil (b). nifH: nitrogenase, amoA AOA: ammonia monooxygenase in ammonia oxidizing archaea, amoB AOB: am

monia monooxygenase in ammonia oxidizing bacteria, narG: nitrate reductase, nirS: iron dependent nitrite reductase, nirK: copper dependent nitrite reductase, nosZ: nitrous-oxide reductase, chiA: chitinase, apr. alkaline protease. Eight biological replicates of two time points were combined. Data indicate mean values $(n=16, \pm$ SE) for NE (black bars) and SW (white bars). Stars indicate significant differences at $\mathrm{P}<0.001^{* \star *}$ and $\mathrm{P}<0.01^{\star *}$.

\subsection{Discussion}

\subsubsection{The difference in $\mathrm{N}$ acquisition by trees of different origin is not due to plant-inherent features}

In this study, we disentangled the influence of the origin of the plants from that of their associated soil-mycorrhizophere microbial community on $\mathrm{N}$ nutrition of young beech trees. Previous genetic and physiological studies with beeches from sites differing in water availability revealed significant differences in tree performance suggesting that adaptation to the environmental conditions may have occurred (Jump et al. 2006; Rose et al. 2009; Pluess and Weber 2012; Weber et al. 2013). However, population analysis with neutral genetic markers in the natural beech regeneration at the SW and NE sites, from where the present plants were collected, did not show pronounced differentiation between the tree origins (Bilela et al. 2012). At the physiological level, the amino acid concentrations in roots can modify uptake of inorganic nitrogen (Geßler et al. 2004b), but here, no significant differences for the different tree origins were observed. Still, SW and NE trees exhibited significant differences in ${ }^{15} \mathrm{~N}$ accumulation when micro-scalic soil heterogeneity, differences in $\mathrm{N}$ supply 
or climatic constraints were relieved. In contrast to our expectation that $\mathrm{N}$ uptake by the SW beeches would be hampered in comparison with the NE beeches as under field conditions (Fotelli et al. 2004; Geßler et al. 2005), higher N influx into the fine roots of the SW trees was found in this study. This result indicates that environmental constraints on the trees or their associated micro-organisms limited $\mathrm{N}$ uptake of the SW trees under field conditions. Plant carbon allocation to the root-rhizosphere system has been identified as an important control for plant N provision (Dannenmann et al. 2009; Näsholm et al. 2013). Higher carbon consumption as indicated by higher respiration occurred, however, in soil from NE than in that from SW trees. This might have been due to the larger root system of NE trees, but not to soil microbes because their biomass in containers with NE trees was similar to those with SW trees. Furthermore, in our study soil respiration was probably dominated by the roots, because soil microbial biomass was one to two orders of magnitude smaller than in forest soil under field conditions (Dannenmann et al. 2006, 2007). The gross soil respiration was apparently fueled by stored carbon because the signature of ${ }^{13} \mathrm{C}$ coming from new photosynthetate was unaffected. Overall, we have no evidence that higher ${ }^{15} \mathrm{~N}$ uptake instantaneously required higher photosynthetic $\mathrm{C}$ allocation to root tips, but the slightly higher ${ }^{13} \mathrm{C}$ signature in fine roots of $\mathrm{SW}$ trees suggests that increased $\mathrm{N}$ nutrition may lead to $\mathrm{C}$ trade-offs in the long run.

We can exclude that the increased $\mathrm{N}$ uptake into the fine roots was due to more efficient $\mathrm{N}$ uptake systems of the trees because no differences in ${ }^{15} \mathrm{~N}$ enrichment were found for the non-mycorrhizal root tips of $\mathrm{NE}$ and $\mathrm{SW}$ trees. Assuming that the $\mathrm{NO}_{3}{ }^{-}$and $\mathrm{NH}_{4}{ }^{+}$levels found per $\mathrm{kg}$ of dry soil were completely dissolved in the soil solution, the $\mathrm{N}$ concentrations were 290 to $360 \mu \mathrm{M}$ for $\mathrm{NH}_{4}{ }^{+}$and $39-44 \mu \mathrm{M}$ for $\mathrm{NO}_{3}{ }^{-}$in the substrate of $\mathrm{NE}$ and SW trees. The $\mathrm{NH}_{4}{ }^{+}$concentrations are in the optimal to excess range for non-mycorrhizal beech roots (Stoelken et al. 2010) and in the saturation range of mycorhizal roots of field grown beeches (Geßler et al. 2005), whereas $\mathrm{NO}_{3}{ }^{-}$is rather in the limiting range. Because of the relatively high fraction of non-mycorrhizal root tips, which exhibited the highest uptake rate of all fractions regardless the plant origin, the overall influx into the roots might have been higher than under field conditions, where we found that the roots of the natural regeneration almost $100 \%$ mycorrhizal. Because the NE trees had a larger root system, the increased ${ }^{15} \mathrm{~N}$ acquisition of the fine roots of the SW trees is also unlikely to be the result of a higher root surface.

It is notable that non-mycorrhizal root tips exhibited the highest $\delta^{13} \mathrm{C}$ signature, suggesting that they are strong sinks for energy. Preferential $C$ allocation to reward more cooperative symbionts of plants compared with less efficient ones has been demonstrated for arbuscular mycorrhizas (Bever et al. 2009; Kiers et al. 2011). Our results suggest that this mechanism may also work for the non-mycorrhizal root tips, which were the most efficient organs for $\mathrm{N}$ uptake under the present unstressed conditions and often superior to mycorrhizal plants (Pena et al. 2013a). However, this will not hold under field conditions because the $\mathrm{N}$ uptake capacity of non-mycorrhizal roots tips is highly vulnerable to environmental fluctuations, such as drought or shading, whereas $\mathrm{N}$ flux through ectomycorrhizal root tips is maintained under stress (Pena and Polle 2014). In conclusion, our findings indicate that non-mycorrhizal root tips contributed significantly to $\mathrm{N}$ flux, but do not support that plant-inherent features including non-mycorrhizal roots were responsible for differences in $\mathrm{N}$ acquisition of the beeches from SW and NE. 


\subsubsection{Mycorrhizal and bacterial contributions to beech $\mathrm{N}$ supply}

The acceleration of $\mathrm{N}$ uptake into the roots of the SW compared to the NE beeches is remarkable because this finding suggests that $\mathrm{N}$ delivery by mycorrhizal and rhizosphere processes were enhanced and/or that the competition by soil microbes was suppressed for the SW trees. Under field conditions, microbes are significant competitors for $\mathrm{N}$ (Dannenmann et al. 2009; Koranda et al. 2011; Guo et al. 2013b) and acquire soluble N faster than EMF (Pena et al. 2013b). Our data support that, in fact, soil microbes accumulated ${ }^{15} \mathrm{~N}$ faster than EMF or roots, but this was a short-term effect overcome within few days. The competition was neither relevant under $\mathrm{N}$ mass balance considerations due to an extremely low microbial activity in our soil system compared to field conditions (here: 3 mg microbial $\mathrm{N} \mathrm{kg}^{-1}$ sdw versus 100 to $300 \mathrm{mg}^{\text {microbial }} \mathrm{N} \mathrm{kg}^{-1}$ sdw in Tuttlingen forest soil, (Dannenmann et al. 2006, 2009). The finding that about $20 \%$ of the added ${ }^{15} \mathrm{~N}$ was recovered in soil microbial biomass and about $13 \%$ in the beech trees further supports that microbial competition for $\mathrm{N}$ was relieved in our system because under field conditions $\mathrm{N}$ uptake by microbial biomass is more than a magnitude larger than by beech natural regeneration (Guo et al. 2013b).

Under our conditions, the SW trees may have benefited from the higher relative abundances of microbes involved in protein and chitin degradation (Apr, chiA) and the potentially higher mobilization rates of $\mathrm{NH}_{4}{ }^{+}$in the RRC. Obviously, the high availability of $\mathrm{NH}_{4}^{+}$reduces competition between trees and microbes for $\mathrm{N}$ to a larger extent in the $\mathrm{RRC}$ of $\mathrm{SW}$ trees because in addition to the observed higher ${ }^{15} \mathrm{~N}$ accumulation in the fine roots also higher abundances of $\mathrm{N}$ consuming microbes like $\mathrm{AOB}$ were found compared to NE trees. The activities of Apr and chiA also imply higher degradation of organic matter in the RRC of SW trees than at those from NE. This is surprising because the substrate was mainly composed of sand. However, the SW trees contained more dead roots, which may have fostered enhanced decomposing activities. The relative increase of denitrifiers as indicated by the higher abundance of nirS might be a direct consequence of the increased turnover of organic matter in the RRC of SW trees and consequently reduced availabilities of oxygen, which in combination with increased $\mathrm{NO}_{3}{ }^{-}$concentrations (due to higher abundance of $A O B$ ) stimulate this process. Under long term conditions degradation of root litter is also important for beech $\mathrm{N}$ supply (Guo et al. 2013a), but this source is unlikely to influence $\mathrm{N}$ nutrition within the time scale of this study.

Although our data support functional differences of bacteria, the similarity of the RS and RRC community structures between NE and SW beech associated assemblages suggest, that the unifying substrate and climatic conditions stratified the RS and RRC assemblages (Fierer and Jackson 2006). This was in sharp contrast to the EMF community. Because ectomycorrhizal root tips have a lifespan from months up to several years (Zhou and Hogetsu 2002; Guidot et al. 2004; Treseder 2004), the observed dissimilarity of the fungal assemblages reflects differences of the SW and NE sites. The SW assemblage exhibited higher EMF species richness and faster and stronger $\mathrm{N}$ accumulation than the NE assemblage. These superior features corresponded to higher $\mathrm{N}$ accumulation in the fine roots of SW trees and higher transport to the leaves and therefore support that the EMF assemblages control $\mathrm{N}$ delivery to the host. Apparently, the structures of divergent EMF assemblages can play decisive roles in the observed variations in beech $\mathrm{N}$ uptake under field conditions (Geßler et al. 2004a). The finding that divergent in situ EMF assemblages exhibit functional diversity is an important result, because variation in EMF species composition and 
abundance has often been interpreted to reflect the adaptation of the fungi to fluctuations of the external conditions, but the consequences for the host were unknown.

In dry ecosystems, ascomycetes are generally more abundant on roots of trees than under moist conditions (Danielson and Pruden 1989; Gehring et al. 1998; Nilsen et al. 1998). Here, ascomycota were also relatively more prevalent in the EMF assemblage of SW roots than the basidiomycota, which dominated on NE roots. The most abundant species of the present study, C. geophilum is well known for its drought tolerance (Jany et al. 2003; Pietro et al. 2007). It maintains $\mathrm{N}$ uptake under unfavorable environmental conditions, when other fungal species show a pronounced decline in N acquisition (Pena and Polle 2014) and persists under limited supply with photosynthetic assimilates (Pena et al. 2010). However, in other studies in which the functions of distinct taxa for $\mathrm{N}$ acquisition were characterized, $C$. geophilum was not the most efficient accumulator of N (Pena et al. 2013b; Pena and Polle 2014) and, thus, may result in trade-offs for tree nutrition in a fluctuating environment.

In conclusion, among the different components of the experimental soil-mycorrhizosphereplant system, the composition of the EMF assemblage was crucial for host $\mathrm{N}$ provision, whereas evidence for physiological differences as the result genetic adaptation or long lasting acclimation due to plant origin was not observed. The differences in soil and mycorrhizosphere microbial communities and activities were mainly driven by the plants suggesting slightly stronger effects of SW than of NE trees on microbial $\mathrm{N}$ cycling. The ability of soil microbes to prevent short-term plant ${ }^{15} \mathrm{~N}$ uptake, despite saturating $\mathrm{N}$ concentrations, underlines that improved mechanistic knowledge of microbial interactions with EMF is required to understand their impact on tree nutrition in fluctuating environments. Our findings highlight that the associated EMF assemblages of beech from contrasting environments exhibit important differences in $\mathrm{N}$ processing in the soil-plant system. To counteract the predicted negative consequences of climate change for forest productivity (Hanewinkel et al. 2013), the identification of drought tolerant beech provenances for the establishment of resistant forests has been suggested (Bolte et al. 2007; Weber et al. 2013). Our results suggest that this strategy will be insufficient when not combined with the application of adapted microbial communities, in particular EMF assemblages, because these communities control tree $\mathrm{N}$ supply, and therefore are crucial for forest productivity in $\mathrm{N}$ limited ecosystems.

\subsection{Acknowledgements}

We are grateful to the German Research Foundation/Deutsche Forschungsgemeinschaft (DFG) for funding this work under contract numbers Po 362/19-1, RE 515/33-1, Da 1217/2-1, SCHL446/12-1. Judy Simon was financially supported by the European Social Fund and by the Ministry of Science, Research and the Arts (Baden-Württemberg).We would also like to thank Dr. Jens Dyckmans (Kompetenzzentrum für Stabile Isotope, University of Göttingen) for isotope analyses, Thomas Klein for ITS sequencing and Maximilian Huber for support during the experimental work. 


\subsection{References}

Agerer R. 1987-2006. Colour Atlas of Ectomycorrhizae. Einhorn Verlag, Schwäbisch-Gmünd.

Albarracín M.V., Six J., Houlton B.Z., Bledsoe C.S. 2013. A nitrogen fertilization field study of carbon-13 and nitrogen-15 transfers in ectomycorrhizas of Pinus sabiniana. Oecologia. 173:1439-1450.

Allen E.B., Allen M.F., Helm D.J., Trappe J.M., Molina R., Rincon E. 1995. Patterns and regulation of mycorrhizal plant and fungal diversity. Plant Soil. 170:47-62.

Bever J.D., Richardson S.C., Lawrence B.M., Holmes J., Watson M. 2009. Preferential allocation to beneficial symbiont with spatial structure maintains mycorrhizal mutualism. Ecol. Lett. 12:13-21.

Bilela S., Dounavi A., Fussi B., Konnert M., Holst J., Mayer H., Rennenberg H., Simon J. 2012. Natural regeneration of Fagus sylvatica L. adapts with maturation to warmer and drier microclimatic conditions. For. Ecol. Manag. 275:60-67.

Bolte A., Czajkowski T., Kompa T. 2007. The north-eastern distribution range of European beech - a review. Forestry. 80:413-429.

Bossio D.A., Scow K.M., Gunapala N., Graham K.J. 1998. Determinants of soil microbial communities: effects of agricultural management, season and soil type on phospholipid fatty acid profiles. Microb. Ecol. 36:1-12.

Bossio D.A., Scow K.M. 1995. Impact of carbon and flooding on the metabolic diversity of microbial communities in soils. Appl. Environ. Microbiol. 61:4043-4050.

Bradley K.L., Hancock J.E., Giardina C.P., Pregitzer K.S. 2007. Soil microbial community responses to altered lignin biosynthesis in Populus tremuloides vary among three distinct soils. Plant Soil. 294:185-201.

Braker G., Fesefeldt A., Witzel K.-P. 1998. Development of PCR primer systems for amplification of nitrite reductase Genes (nirK and nirS) to detect denitrifying bacteria in environmental samples. Appl. Environ. Microbiol. 64:3769-3775.

Bru D., Sarr A., Philippot L. 2007. Relative abundances of proteobacterial membrane-bound and periplasmic nitrate reductases in selected environments. Appl. Environ. Microbiol. 73:5971-5974.

Buée M., Vairelles D., Garbaye J. 2005. Year-round monitoring of diversity and potential metabolic activity of the ectomycorrhizal community in a beech (Fagus silvatica) forest subjected to two thinning regimes. Mycorrhiza. 15:235-245.

Bulgarelli D., Schlaeppi K., Spaepen S., van Themaat E.V.L., Schulze-Lefert P. 2013. Structure and functions of the bacterial microbiota of plants. Annu. Rev. Plant Biol. 64:807838. 
Chao A., Jost L., Chiang S.C., Jiang Y.-H., Chazdon R.L. 2008. A two-stage probabilistic approach to multiple-community similarity indices. Biometrics. 64:1178-1186.

Corrêa A., Strasser R.J., Martins-Loução M.A. 2008. Response of plants to ectomycorrhizae in N-limited conditions: which factors determine its variation? Mycorrhiza. 18:413-427.

Danielsen L., Lohaus G., Sirrenberg A., Karlovsky P., Bastien C., Pilate G., Polle A. 2013. Ectomycorrhizal colonization and diversity in relation to tree biomass and nutrition in a plantation of transgenic poplars with modified lignin biosynthesis. PLoS ONE. 8:e59207.

Danielson R.M., Pruden M. 1989. The ectomycorrhizal status of urban spruce. Mycologia. 81:335.

Dannenmann M., Gasche R., Ledebuhr A., Holst T., Mayer H., Papen H. 2007. The effect of forest management on trace gas exchange at the pedosphere-atmosphere interface in beech (Fagus sylvatica L.) forests stocking on calcareous soils. Eur. J. For. Res. 126:331346.

Dannenmann M., Gasche R., Ledebuhr A., Papen H. 2006. Effects of forest management on soil N cycling in beech forests stocking on calcareous soils. Plant Soil. 287:279-300.

Dannenmann M., Simon J., Gasche R., Holst J., Naumann P.S., Kögel-Knabner I., Knicker H., Mayer H., Schloter M., Pena R., Polle A., Rennenberg H., Papen H. 2009. Tree girdling provides insight on the role of labile carbon in nitrogen partitioning between soil microorganisms and adult European beech. Soil Biol. Biochem. 41:1622-1631.

Druebert C., Lang C., Valtanen K., Polle A. 2009. Beech carbon productivity as driver of ectomycorrhizal abundance and diversity. Plant Cell Environ. 32:992-1003.

Dyckmans J. 2000. Untersuchung der Aufnahme und Translokation von $\mathrm{C}$ und $\mathrm{N}$ in Buchen in Abhängigkeit der atmosphärischen $\mathrm{CO}_{2}$-Konzentration und bauminternen $\mathrm{N}$-Vorräte unter Einsatz der stabilen Isotope ${ }^{15} \mathrm{~N}$ und ${ }^{13} \mathrm{C}$. eDiss, Göttingen.

Ellenberg H., Strutt G. 2009. Vegetation ecology of Central Europe. Cambridge; New York: Cambridge University Press.

Fierer N., Jackson R.B. 2006. The diversity and biogeography of soil bacterial communities. Proc. Natl. Acad. Sci. U. S. A. 103:626-631.

Fotelli M.N., Rienks M., Rennenberg H., Geßler A. 2004. Climate and forest management affect ${ }^{15} \mathrm{~N}$-uptake, $\mathrm{N}$ balance and biomass of European beech seedlings. Trees. 18:157-166.

Gardes M., Bruns T.D. 1993. ITS primers with enhanced specificity for basidiomycetes application to the identification of mycorrhizae and rusts. Mol. Ecol. 2:113-118. 
Gehring C.A., Theimer T.C., Whitham T.G., Keim P. 1998. Ectomycorrhizal fungal community structure of Pinyon Pines growing in two environmental extremes. Ecology. 79:1562-1572.

Geßler A., Jung K., Gasche R., Papen H., Heidenfelder A., Börner E., Metzler B., Augustin S., Hildebrand E., Rennenberg H. 2005. Climate and forest management influence nitrogen balance of European beech forests: microbial $\mathrm{N}$ transformations and inorganic $\mathrm{N}$ net uptake capacity of mycorrhizal roots. Eur. J. For. Res. 124:95-111.

Geßler A., Keitel C., Nahm M., Rennenberg H. 2004a. Water shortage affects the water and nitrogen balance in Central European beech forests. Plant Biol. 6:289-298.

Geßler A., Kopriva S., Rennenberg H. 2004b. Regulation of nitrate uptake at the whole-tree level: interaction between nitrogen compounds, cytokinins and carbon metabolism. Tree Physiol. 24:1313-1321.

Geßler A., Schrempp S., Matzarakis A., Mayer H., Rennenberg H., Adams M.A. 2001. Radiation modifies the effect of water availability on the carbon isotope composition of beech (Fagus sylvatica). New Phytol. 150:653-664.

Gschwendtner S., Reichmann M., Müller M., Radl V., Munch J.C., Schloter M. 2010. Effects of genetically modified amylopectin-accumulating potato plants on the abundance of beneficial and pathogenic microorganisms in the rhizosphere. Plant Soil. 335:413-422.

Guidot A., Debaud J.-C., Effosse A., Marmeisse R. 2004. Below-ground distribution and persistence of an ectomycorrhizal fungus. New Phytol. 161:539-547.

Guo C., Dannenmann M., Gasche R., Zeller B., Papen H., Polle A., Rennenberg H., Simon J. 2013a. Preferential use of root litter compared to leaf litter by beech seedlings and soil microorganisms. Plant Soil. 368:519-534.

Guo C., Simon J., Gasche R., Naumann P.S., Bimüller C., Pena R., Polle A., Kögel-Knabner I., Zeller B., Rennenberg H., Dannenmann M. 2013b. Minor contribution of leaf litter to N nutrition of beech (Fagus sylvatica) seedlings in a mountainous beech forest of Southern Germany. Plant Soil. 369:657-668.

Hammer $\varnothing .$, Harper D.A.T., Ryan P.D. 2001. PAST-Palaeontological statistics. Palaeontologia Electronica 4(1): 9pp. http://palaeo-electronica.org/2001_1/past/ issue1_01.htm.

Hanewinkel M., Cullmann D.A., Schelhaas M.-J., Nabuurs G.-J., Zimmermann N.E. 2013. Climate change may cause severe loss in the economic value of European forest land. Nat. Clim. Change. 3:203-207.

Henry S., Baudoin E., López-Gutiérrez J.C., Martin-Laurent F., Brauman A., Philippot L. 2004. Quantification of denitrifying bacteria in soils by nirK gene targeted real-time PCR. J. Microbiol. Methods. 59:327-335. 
Henry S., Bru D., Stres B., Hallet S., Philippot L. 2006. Quantitative detection of the nosZ gene, encoding nitrous oxide reductase, and comparison of the abundances of 16S rRNA, narG, nirK and nosZ genes in soils. Appl. Environ. Microbiol. 72:5181-5189.

Holst J., Grote R., Offermann C., Ferrio J.P., Geßler A., Mayer H., Rennenberg H. 2010. Water fluxes within beech stands in complex terrain. Int. J. Biometeorol. 54:23-36.

International Union of Soil Sciences Working Group WRB. 2007. World Reference Base for Soil Resources 2006, First Update 2007. Rome.

Jany J.-L., Martin F., Garbaye J. 2003. Respiration activity of ectomycorrhizas from Cenococcum geophilum and Lactarius $\mathrm{sp}$. in relation to soil water potential in five beech forests. Plant Soil. 255:487-494.

Jump A.S., Hunt J.M., Martínez-Izquierdo J.A., Peñuelas J. 2006. Natural selection and climate change: temperature-linked spatial and temporal trends in gene frequency in Fagus sylvatica. Mol. Ecol. 15:3469-3480.

Kaiser C., Koranda M., Kitzler B., Fuchslueger L., Schnecker J., Schweiger P., Rasche F., Zechmeister-Boltenstern S., Sessitsch A., Richter A. 2010. Belowground carbon allocation by trees drives seasonal patterns of extracellular enzyme activities by altering microbial community composition in a beech forest soil. New Phytol. 187:843-858.

Keitel C., Adams M.A., Holst T., Matzarakis A., Mayer H., Rennenberg H., Geßler A. 2003. Carbon and oxygen isotope composition of organic compounds in the phloem sap provides a short-term measure for stomatal conductance of European beech (Fagus sylvatica L.). Plant Cell Environ. 26:1157-1168.

Keitel C., Matzarakis A., Rennenberg H., Gessler A. 2006. Carbon isotopic composition and oxygen isotopic enrichment in phloem and total leaf organic matter of European beech (Fagus sylvatica L.) along a climate gradient. Plant Cell Environ. 29:1492-1507.

Kiers E.T., Duhamel M., Beesetty Y., Mensah J.A., Franken O., Verbruggen E., Fellbaum C.R., Kowalchuk G.A., Hart M.M., Bago A., Palmer T.M., West S.A., Vandenkoornhuyse P., Jansa J., Bücking H. 2011. Reciprocal rewards stabilize cooperation in the mycorrhizal symbiosis. Science. 333:880-882.

Koranda M., Schnecker J., Kaiser C., Fuchslueger L., Kitzler B., Stange C.F., Sessitsch A., Zechmeister-Boltenstern S., Richter A. 2011. Microbial processes and community composition in the rhizosphere of European beech - The influence of plant $\mathrm{C}$ exudates. Soil Biol. Biochem. 43:551-558.

Lang C., Seven J., Polle A. 2011. Host preferences and differential contributions of deciduous tree species shape mycorrhizal species richness in a mixed Central European forest.

Mycorrhiza. 21:297-308. 
Leininger S., Urich T., Schloter M., Schwark L., Qi J., Nicol G.W., Prosser J.I., Schuster S.C., Schleper C. 2006. Archaea predominate among ammonia-oxidizing prokaryotes in soils. Nature. 442:806-809.

Luo Z.-B., Janz D., Jiang X., Göbel C., Wildhagen H., Tan Y., Rennenberg H., Feussner I., Polle A. 2009. Upgrading root physiology for stress tolerance by ectomycorrhizas: insights from metabolite and transcriptional profiling into reprogramming for stress anticipation. Plant Physiol. 151:1902-1917.

Meier I.C., Leuschner C. 2008. Belowground drought response of European beech: fine root biomass and carbon partitioning in 14 mature stands across a precipitation gradient. Glob. Change Biol. 14:2081-2095.

Michotey V., Méjean V., Bonin P. 2000. Comparison of methods for quantification of cytochrome cd 1-denitrifying bacteria in environmental marine samples. Appl. Environ. Microbiol. 66:1564-1571.

Mogge B., Loferer C., Agerer R., Hutzler P., Hartmann A. 2000. Bacterial community structure and colonization patterns of Fagus sylvatica L. ectomycorrhizospheres as determined by fluorescence in situ hybridization and confocal laser scanning microscopy. Mycorrhiza. 9:271-278.

Näsholm T., Högberg P., Franklin O., Metcalfe D., Keel S.G., Campbell C., Hurry V., Linder S., Högberg M.N. 2013. Are ectomycorrhizal fungi alleviating or aggravating nitrogen limitation of tree growth in boreal forests? New Phytol. 198:214-221.

Nilsen P., Børja I., Knutsen H., Brean R. 1998. Nitrogen and drought effects on ectomycorrhizae of Norway spruce [Picea abies L.(Karst.)]. Plant Soil. 198:179-184.

Pena R., Offermann C., Simon J., Naumann P.S., Geßler A., Holst J., Dannenmann M., Mayer H., Kogel-Knabner I., Rennenberg H., Polle A. 2010. Girdling affects ectomycorrhizal fungal (EMF) diversity and reveals functional differences in EMF community composition in a beech forest. Appl. Environ. Microbiol. 76:1831-1841.

Pena R., Polle A. 2014. Attributing functions to ectomycorrhizal fungal identities in assemblages for nitrogen acquisition under stress. ISME J. DOI: 10.1038/ismej.2013.158.

Pena R., Simon J., Rennenberg H., Polle A. 2013a. Ectomycorrhiza affect architecture and nitrogen partitioning of beech (Fagus sylvatica L.) seedlings under shade and drought. Environ. Exp. Bot. 87:207-217.

Pena R., Tejedor J., Zeller B., Dannenmann M., Polle A. 2013b. Interspecific temporal and spatial differences in the acquisition of litter-derived nitrogen by ectomycorrhizal fungal assemblages. New Phytol. 199:520-528.

Perakis S.S., Hedin L.O. 2001. Fluxes and fates of nitrogen in soil of an unpolluted oldgrowth temperate forest, southern Chile. Ecology. 82:2245-2260. 
Pettersson M., Bååth E. 2003. Temperature-dependent changes in the soil bacterial community in limed and unlimed soil. FEMS Microbiol. Ecol. 45:13-21.

Pietro M. di, Churin J.-L., Garbaye J. 2007. Differential ability of ectomycorrhizas to survive drying. Mycorrhiza. 17:547-550.

Pluess A.R., Weber P. 2012. Drought-adaptation potential in Fagus sylvatica: linking moisture availability with genetic diversity and dendrochronology. PLoS ONE. 7:e33636.

Rasche F., Knapp D., Kaiser C., Koranda M., Kitzler B., Zechmeister-Boltenstern S., Richter A., Sessitsch A. 2011. Seasonality and resource availability control bacterial and archaeal communities in soils of a temperate beech forest. ISME J. 5:389-402.

Read D.J., Perez-Moreno J. 2003. Mycorrhizas and nutrient cycling in ecosystems-a journey towards relevance? New Phytol. 157:475-492.

Rennenberg H., Dannenmann M., Geßler A., Kreuzwieser J., Simon J., Papen H. 2009. Nitrogen balance in forest soils: nutritional limitation of plants under climate change stresses. Plant Biol. 11:4-23.

Ritter E., Dalsgaard L., Einhorn K.S. 2005. Light, temperature and soil moisture regimes following gap formation in a semi-natural beech-dominated forest in Denmark. For. Ecol. Manag. 206:15-33.

Rose L., Leuschner C., Köckemann B., Buschmann H. 2009. Are marginal beech (Fagus sylvatica L.) provenances a source for drought tolerant ecotypes? Eur. J. For. Res. 128:335343.

Rösch C., Mergel A., Bothe H. 2002. Biodiversity of denitrifying and dinitrogen-fixing bacteria in an acid forest soil. Appl. Environ. Microbiol. 68:3818-3829.

Rotthauwe J.H., Witzel K.P., Liesack W. 1997. The ammonia monooxygenase structural gene amoA as a functional marker: molecular fine-scale analysis of natural ammoniaoxidizing populations. Appl. Environ. Microbiol. 63:4704-4712.

Schauss K., Focks A., Leininger S., Kotzerke A., Heuer H., Thiele-Bruhn S., Sharma S., Wilke B.-M., Matthies M., Smalla K., Munch J.C., Amelung W., Kaupenjohann M., Schloter M., Schleper C. 2009. Dynamics and functional relevance of ammonia-oxidizing archaea in two agricultural soils. Environ. Microbiol. 11:446-456.

Schloter M., Winkler J.B., Aneja M., Koch N., Fleischmann F., Pritsch K., Heller W., Stich S., Grams T.E.E., Göttlein A., Matyssek R., Munch J.C. 2005. Short term effects of ozone on the plant-rhizosphere-bulk soil system of young beech trees. Plant Biol. 7:728-736.

Schreiner K., Hagn A., Kyselková M., Moënne-Loccoz Y., Welzl G., Munch J.C., Schloter M. 2010. Comparison of barley succession and take-all disease as environmental factors 
shaping the rhizobacterial community during take-all decline. Appl. Environ. Microbiol. 76:4703-4712.

Shi L., Guttenberger M., Kottke I., Hampp R. 2002. The effect of drought on mycorrhizas of beech (Fagus sylvatica L.): changes in community structure, and the content of carbohydrates and nitrogen storage bodies of the fungi. Mycorrhiza. 12:303-311.

Solberg S., Dobbertin M., Reinds G.J., Lange H., Andreassen K., Fernandez P.G., Hildingsson A., de Vries W. 2009. Analyses of the impact of changes in atmospheric deposition and climate on forest growth in European monitoring plots: A stand growth approach. For. Ecol. Manag. 258:1735-1750.

Stoelken G., Simon J., Ehlting B., Rennenberg H. 2010. The presence of amino acids affects inorganic $\mathrm{N}$ uptake in non-mycorrhizal seedlings of European beech (Fagus sylvatica). Tree Physiol. 30:1118-1128.

Throbäck I.N., Enwall K., Jarvis Å., Hallin S. 2004. Reassessing PCR primers targeting nirS, nirK and nosZ genes for community surveys of denitrifying bacteria with DGGE. FEMS Microbiol. Ecol. 49:401-417.

Treseder K.K. 2004. A meta-analysis of mycorrhizal responses to nitrogen, phosphorus, and atmospheric CO2 in field studies. New Phytol. 164:347-355.

Weber P., Bugmann H., Pluess A.R., Walthert L., Rigling A. 2013. Drought response and changing mean sensitivity of European beech close to the dry distribution limit. Trees. 27:171-181.

White T.J., Bruns T. d, Lee S. 1990. Amplification and direct sequencing of fungal ribosomal RNA genes for phylogenetics. PCR Protoc. Guide Methods Appl. Eds MA Innis DH Gelfand JJ Sninsky TJ White Acad. Press N. Y. 315-322.

Winkler J.B., Dannenmann M., Simon J., Pena R., Offermann C., Sternad W., Clemenz C., Naumann P.S., Gasche R., Kögel-Knabner I., Geßler A., Rennenberg H., Polle A. 2010. Carbon and nitrogen balance in beech roots under competitive pressure of soil-borne microorganisms induced by girdling, drought and glucose application. Funct. Plant Biol. $37: 879-889$.

Winter H., Lohaus G., Heldt H.W. 1992. Phloem transport of amino acids in relation to their cytosolic levels in barley leaves. Plant Physiol. 99:996-1004.

Wu H., Dannenmann M., Fanselow N., Wolf B., Yao Z., Wu X., Brüggemann N., Zheng X., Han X., Dittert K., Butterbach-Bahl K. 2011. Feedback of grazing on gross rates of N mineralization and inorganic $\mathrm{N}$ partitioning in steppe soils of Inner Mongolia. Plant Soil. 340:127-139.

Wu X., Yao Z., Brüggemann N., Shen Z.Y., Wolf B., Dannenmann M., Zheng X., ButterbachBahl K. 2010. Effects of soil moisture and temperature on $\mathrm{CO}_{2}$ and $\mathrm{CH}_{4}$ soil-atmosphere 
exchange of various land use/cover types in a semi-arid grassland in Inner Mongolia, China. Soil Biol. Biochem. 42:773-787.

Xiao X., Yin X., Lin J., Sun L., You Z., Wang P., Wang F. 2005. Chitinase genes in lake sediments of Ardley Island, Antarctica. Appl. Environ. Microbiol. 71:7904-7909.

Zhou Z., Hogetsu T. 2002. Subterranean community structure of ectomycorrhizal fungi under Suillus grevillei sporocarps in a Larix kaempferi forest. New Phytol. 154:529-539. 


\section{Climate change impairs nitrogen cycling in European beech forests}

Michael Dannenmann ${ }^{\mathrm{A}, \mathrm{B}^{*}}$ Carolin Bimüller ${ }^{\mathrm{C}}$, Silvia Gschwendtner ${ }^{\mathrm{D}}$, Martin Leberecht ${ }^{\mathrm{E}}$, Javier Tejedor $^{\mathrm{A}}$, Silvija Bilela ${ }^{\mathrm{B}}$, Rainer Gasche ${ }^{\mathrm{A}}$, Marc Hanewinkel ${ }^{\mathrm{H}}$, Andri Baltensweiler ${ }^{\mathrm{H}}$, Ingrid Kögel-Knabner $^{\mathrm{C}, \mathrm{F}}$, Andrea Polle ${ }^{\mathrm{E}}$, Michael Schloter ${ }^{\mathrm{D}}$, Judy Simon ${ }^{\mathrm{B}}$, Heinz Rennenberg ${ }^{\mathrm{B}, \mathrm{G}}$

${ }^{A}$ Institute for Meteorology and Climate Research, Atmospheric Environmental Research (IMK-IFU), Karlsruhe Institute of Technology (KIT), Kreuzeckbahnstrasse 19, 82467 Garmisch-Partenkirchen, Germany ${ }^{B}$ Institute of Forest Sciences, Chair of Tree Physiology, University of Freiburg; GeorgesKoehler-Allee 53/54, 79110 Freiburg, Germany

${ }^{c}$ Lehrstuhl für Bodenkunde, Department für Ökologie und Ökosystemmanagement, Wissenschaftszentrum Weihenstephan. Technische Universität München, 85350 FreisingWeihenstephan, Germany

${ }^{D}$ Environmental Genomics, Helmholtz Zentrum München, German Research Center for Environmental Health, Ingolstädter Landstr. 1, 85764 Neuherberg, Germany

${ }^{E}$ Forest Botany and Tree Physiology, Büsgen-Institute, Georg-August Universität Göttingen, Büsgenweg 2, 37077 Göttingen, Germany

${ }^{F}$ IAS-Institute for Advanced Study, Technische Universität München, Lichtenbergstraße 2a, D-85748 Garching, Germany

${ }^{G}$ King Saud University, PO Box 2454, Riyadh 11451, Saudi Arabia

${ }^{H}$ Research Unit Forest Resources and Management, Swiss Federal Research Institute WSL, Zuercherstrasse 111, CH-8903 Birmensdorf, Switzerland

Submitted on 09.11.2013 to Nature Geoscience

\subsection{Introducing Abstract}

The vulnerability of European beech forest ecosystems to reduced soil water availability in a changing climate has been associated with large-scale loss of ecological services and economical value (Geßler et al. 2007; Meier and Leuschner 2010; Hanewinkel et al. 2013a). However, the mechanisms of climate change impacts on European beech forests are largely unknown. It has been proposed that reduced soil water availability may promote nitrogen $(\mathrm{N})$ limitation of European beech due to impaired microbial $\mathrm{N}$ cycling in soil (Rennenberg et al. 2009), but this hypothesis has not yet been tested (Kreuzwieser and Gessler 2010). Here we present data on the influence of climate change on $\mathrm{N}$ transformation in the plant-soil interface in situ, using intact beech seedling-soil-microbe systems covering plant as well as soil microbial $\mathrm{N}$ turnover processes. We show that nitrate $\left(\mathrm{NO}_{3}{ }^{-}\right)$is the dominant $\mathrm{N}$ source for beech natural regeneration. Reduced soil water content resulted in a persistent decline of ammonia oxidizing bacteria and therefore, in a massive attenuation of gross nitrification and $\mathrm{NO}_{3}{ }^{-}$availability in the soil. Consequently, $\mathrm{NO}_{3}{ }^{-}$and total $\mathrm{N}$ uptake by beech seedlings were strongly reduced. Already after two growing seasons under simulated climate change conditions, this resulted in a strongly reduced performance of beech seedlings, but also in reduced soil microbial biomass. These findings support a dramatic decline by $78 \%$ of the 
distribution of beech forests on calcareous soils in Europe until 2080 predicted by statistical modelling. Therefore, the present results question the sustainability of this widespread ecosystem on marginal soils already in the near future.

\subsection{Results and Discussion}

4.2.1 European beech forests on calcareous soil are endangered by climate change European beech (Fagus sylvatica L.) dominates the natural forest vegetation in moist to moderately dry areas of the sub-mountainous altitude range in Central Europe (Ellenberg and Leuschner 1996). One third of the potential beech forest area is spread on calcareous soil (Fig. 4.1) that is highly susceptible to water deprivation. For future forestry in Central Europe, it has even been suggested to replace spruce by beech (Tarp et al. 2000; Moosmayer 2002). However, the apparent drought sensitivity of beech is a current matter of concern and debate (Leuschner et al. 2001; Rennenberg et al. 2006, 2009; Geßler et al. 2007; Kreuzwieser and Gessler 2010), due to observations of increased heat waves and drought periods in wide regions of Central Europe (Coumou et al. 2013). This trend is expected to continue and intensify in the coming decades (Seneviratne et al. 2006; Smiatek et al. 2009). Based on statistical species distribution models driven by climatic predictors (Hanewinkel et al. $2013 \mathrm{a}, \mathrm{b}$ ), we computed the distribution range of beech forests on calcareous soil in Europe and found drastic reductions by almost $80 \%$ under an SRES A2 scenario (IPCC 2000) until the year 2080 (Fig. 4.1). However, the physiological processes behind this dramatic biome shift on calcareous soil are rarely understood.

Two different mechanisms have been proposed to explain the sensitivity of beech to increased temperature and drought (Geßler et al. 2007; Rennenberg et al. 2009; Kreuzwieser and Gessler 2010): (1) physiological limitations such as xylem embolism, restricted nutrient uptake capacity and reduced growth; and (2) impaired provision of bioavailable $\mathrm{N}$ by soil microbes. The latter mechanism may be of particular importance in calcareous soil, because Rendzic Leptosols derived from limestone are poor in bioavailable $\mathrm{N}$ (Dannenmann et al. 2006, 2009). Furthermore, these soils are characterized by a shallow profile, high gravel content, heavy texture, and low water and nutrient retention capacity. Hence, $\mathrm{N}$ is frequently limiting growth of this forest type (Dannenmann et al. 2009; Rennenberg et al. 2009; Simon et al. 2011; Weber et al. 2013). 


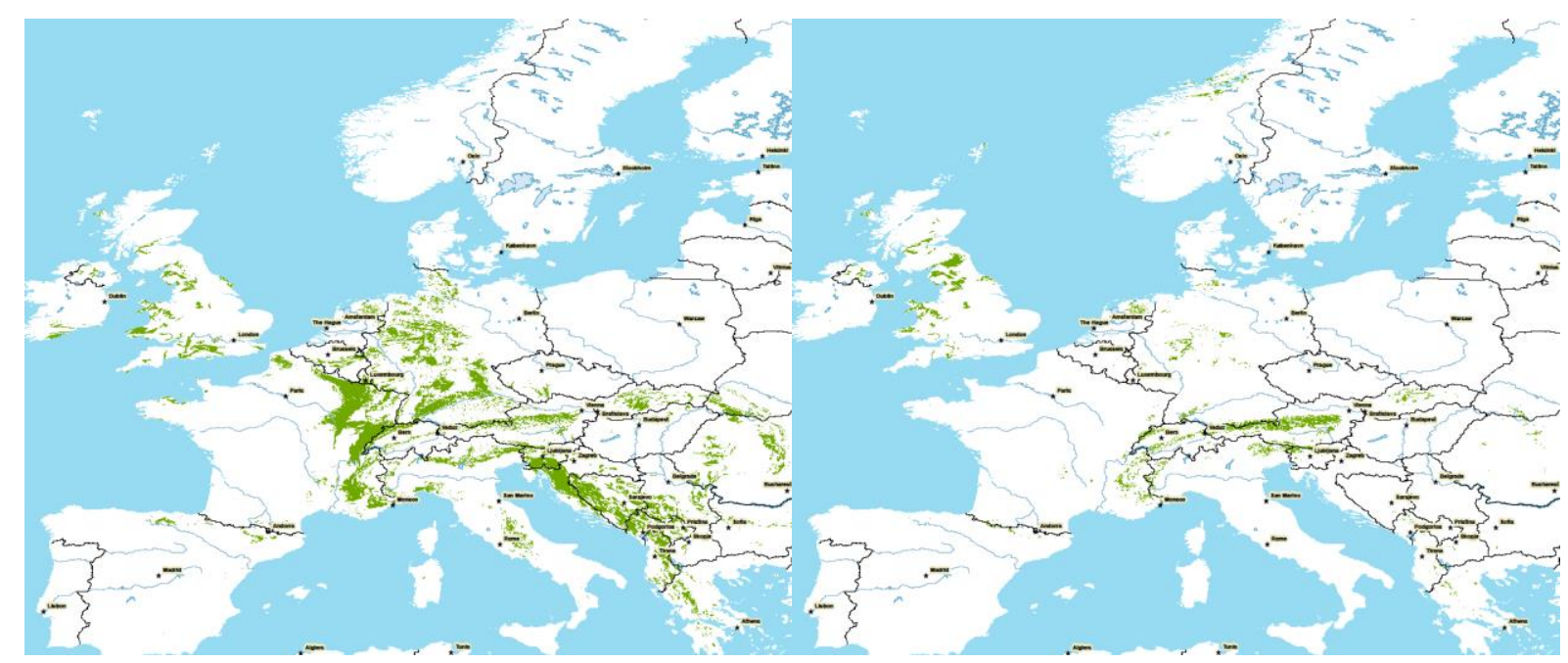

Figure 4.1: Modelled potential distribution of beech forests on calcareous soils in Europe (green colour) under current climatic conditions (left panel). These forests would cover an area of 31.4 million ha, i. e. approximately one third of the potential beech forests in Europe (104.0 million ha). For the SRES A2 scenario (IPCC 2000), we computed a potential distribution of 7.2 million ha in the year 2080 (right panel), i. e. a reduction to $22 \%$ of the current distribution.

Here we present an isotope-based experimental approach to simultaneously quantify all major $\mathrm{N}$ turnover processes in undisturbed beech seedling-soil-microbe systems, thereby maintaining plant-soil microbe interaction and-competition for $\mathrm{N}$. By translocation of intact soil mesocosms containing natural beech regeneration across a narrow valley from the northwest (NW) the southwest (SW) aspect, we combined this approach with a space-fortime climate change experiment (Fig. 4.2). This treatment increased soil temperature on average by $1^{\circ} \mathrm{C}$ (Fig. 4.3) and persistently decreased soil water availability over the entire growing season (Figs. 4.4, 4.5). The NW exposure corresponds to a model climate for present day conditions of many beech forests in Central Europe, while the SW exposure is considered a model for climatic conditions expected for the coming decades (Geßler et al. 2004). Additionally, a roof system accelerated drought during a 39 days period at SW aspect (Fig. 4.4). Supporting measurements included microbial $\mathrm{N}$ cycle gene abundances, mycorrhizal colonization and $\mathrm{N}$ metabolite levels in fine roots as well as plant biomass and long-term isotope recovery in beech seedlings. 


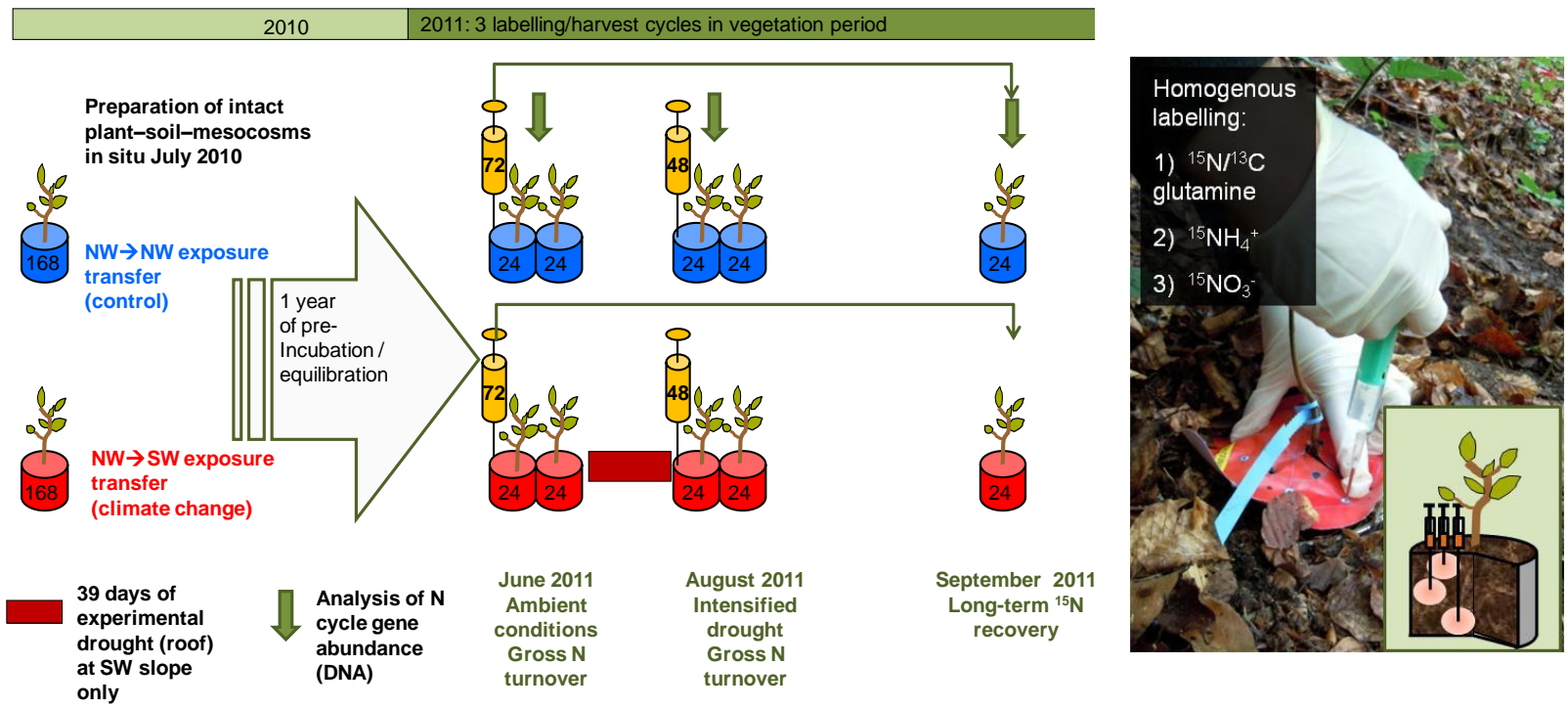

Figure 4.2: Experimental design. The figure illustrates coring of beech-soil-mesocosms by use of stainless steel cylinders (16.4 cm inner diameter, $15 \mathrm{~cm}$ height) with subsequent pre-incubation for one year either under cool-moist microclimate at the coring site (NW exposure, control) or warm-dry microclimate (SW-exposure, climate change). After pre-incubation and equilibration, homogenous and reproducible labelling of the intact plant-soil-microbe systems (40 injections per beech-soil-mesocosm) with ${ }^{15} \mathrm{~N} /{ }^{13} \mathrm{C}$-enriched glutamine, ${ }^{15} \mathrm{~N}$-ammonium $\left(\mathrm{NH}_{4}{ }^{+}\right)$or ${ }^{15} \mathrm{~N}$-nitrate $\left(\mathrm{NO}_{3}{ }^{-}\right)$and subsequent double harvests ( 6 and 48 hours after labelling) were conducted twice. Analysis of total $\mathrm{N}$ and ${ }^{15} \mathrm{~N}$ enrichment in soil, microbial, mycorrhizal and plant $\mathrm{N}$ pools facilitated determination of simultaneously occurring gross $\mathrm{N}$ turnover rates in the plant-soil-microbe system in June (comparison of ambient NW vs. SW climatic conditions) and August (ambient NW conditions vs. roof-intensified drought at SW) via ${ }^{15} \mathrm{~N}$ tracing and pool dilution calculations, while plant-soil microbe interaction and competition for $\mathrm{N}$ persisted throughout the experimental incubation period. A final harvest of mesocosms labelled in June allowed investigating long-term isotope recovery in September. All three harvest dates were accompanied by determination of supporting soil and plant parameters such as microbial $\mathrm{N}$ cycle gene abundance, mycorrhization and ${ }^{15} \mathrm{~N}$ signature of mycorrhizal root tips, and plant metabolites.

Generally, the replication was $n=8$ for every harvesting date, exposure treatment, and labelling treatment. Parallel harvests of unlabelled beech-soil-mesocosms $(n=4$ to 8$)$ were conducted in order to quantify ${ }^{15} \mathrm{~N}$ natural abundance and background $\mathrm{N}$ concentrations (not shown in the graph). 


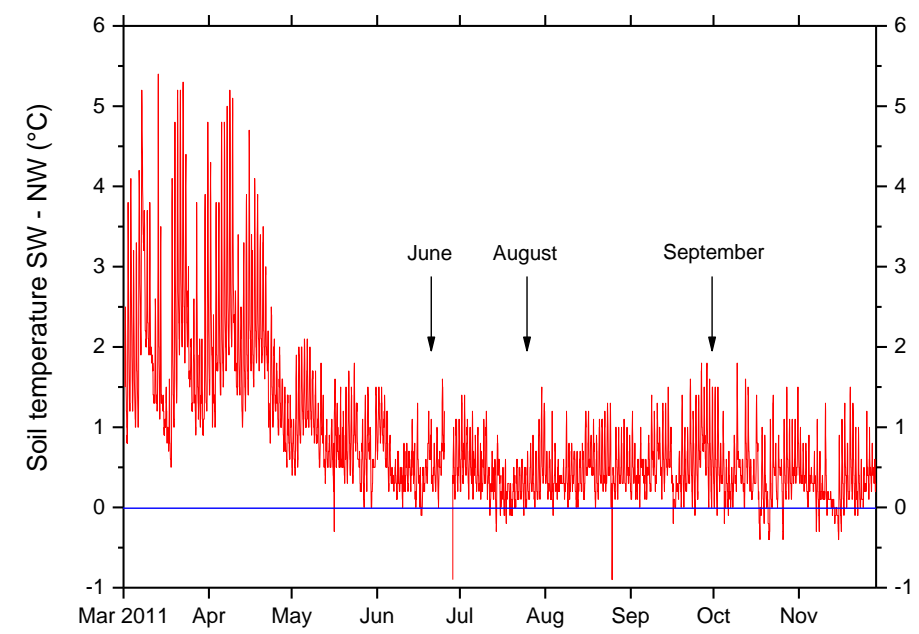

Figure 4.3: Soil temperature differences $(5 \mathrm{~cm}$ depth) between beech-soil-mesocosms incubated at SW exposure (warm-dry microclimate, climate change treatment) and at NW exposure (cool-moist microclimate, control treatment). Data represent mean values of five temperature probes per treatment directly installed horizontally in soil of transferred beech-soil-mesocosms. Arrows indicate the three harvest campaigns. The period between the harvests in June and September equals the roof period of 39 days (see Fig. 4.2).

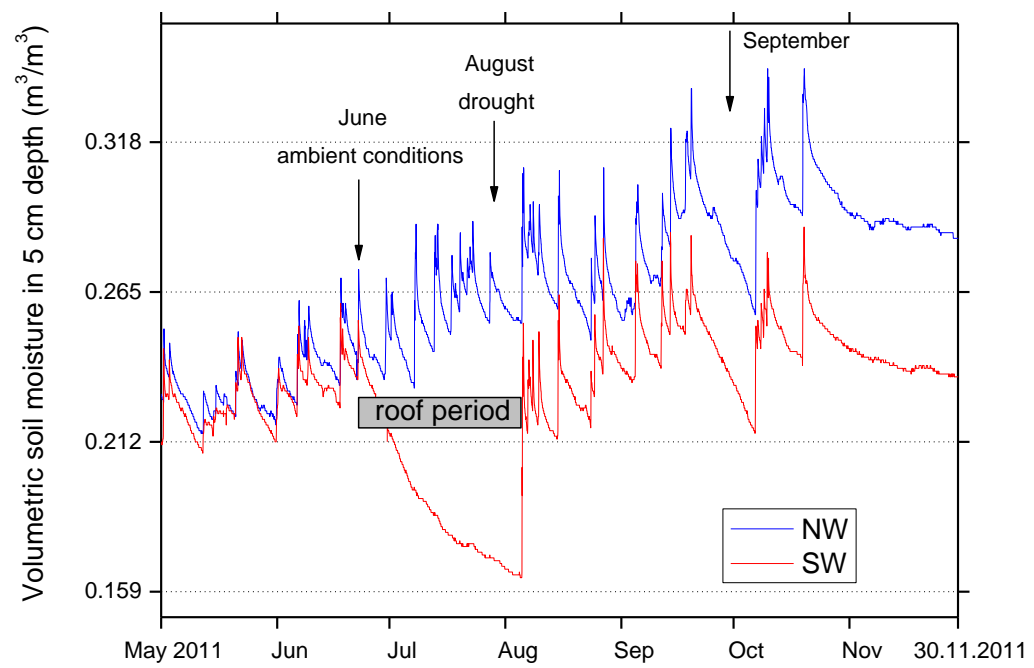

Figure 4.4: Dynamics of volumetric soil moisture in $5 \mathrm{~cm}$ depth (mean values of $n=5$ measurements) in intact beech-soil-mesocosms of the control treatment (NW exposure, cool-moist microclimate) and climate change treatment (SW exposure, warm-dry microclimate) in the growing season 2011 , i. e. 1 year after implementation of treatments by transferring beech seedling-soil-mesocosms within NW exposure or to SW exposure in summer 2010. Arrows indicate harvest campaigns (see Fig. 4.2). 


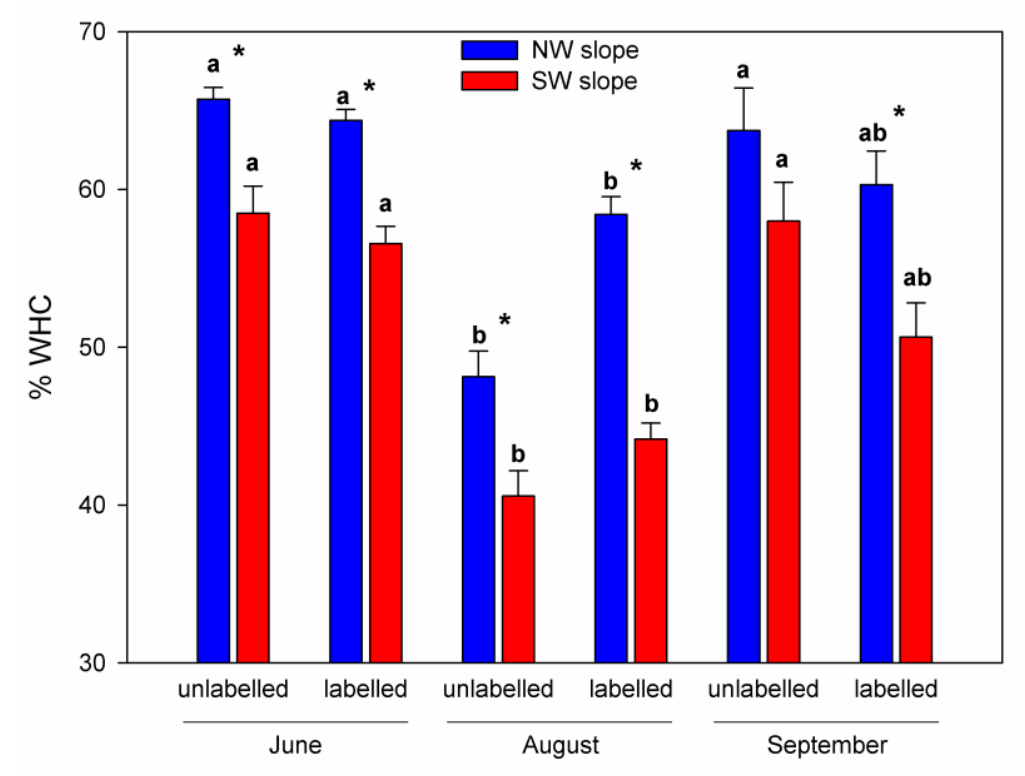

Figure 4.5: Gravimetric soil moisture related to water holding capacity $(\mathrm{WHC})$ as determined from harvested labelled $(n=48)$ and unlabelled $(n=4$ to 8 ) beech-soil-mesocosms during harvests in June (ambient conditions at both exposures), August (intensified drought at SW exposure due to roof) and September (final harvest). Asterisks indicate significant differences $(p<0.05)$ between NW and SW exposure at the respective harvest. Different indices indicate significant differences between different harvesting dates and labelled and unlabelled beech-soil-mesocosms.

\subsubsection{Climate change decelerates beech $\mathrm{N}$ nutrition as a consequence of impaired nitrification}

Ammonification, nitrification and microbial immobilization of inorganic $\mathrm{N}$ were approximately one order of magnitude larger than plant uptake (Fig. 4.6). Microbial biomass $\mathrm{N}$ was several times larger than the plant $\mathrm{N}$ pool (Fig. 4.6). Extractable soil ammonium $\left(\mathrm{NH}_{4}{ }^{+}\right)$and $\mathrm{NO}_{3}{ }^{-}$ pools were in the magnitude of daily rates of gross inorganic $\mathrm{N}$ production and consumption so that microbial turnover largely controlled soil inorganic $\mathrm{N}$ availability. Nitrate was the dominant $\mathrm{N}$ source for beech seedlings in June, followed by $\mathrm{NH}_{4}{ }^{+}$, whereas organic $\mathrm{N}$ supplied as glutamine was hardly recovered (Fig. 4.6). Significantly larger N uptake in June than in August (Fig. 4.6) confirmed an earlier study investigating $N$ uptake capacities of adult beech and beech seedlings. This study showed that the onset of the growing season is a key period for $\mathrm{N}$ acquisition by beech seedlings as part of a competition avoidance strategy with adult beech, which preferentially take up N later in the season (Simon et al. 2011). Such studies on $\mathrm{N}$ uptake capacity also indicate that glutamine is of high importance for $\mathrm{N}$ nutrition of beech (Simon et al. 2010, 2011; Stoelken et al. 2010). Here, the application of doublelabelled ${ }^{13} \mathrm{C}$-carbon $\left({ }^{13} \mathrm{C}\right) /{ }^{15} \mathrm{~N}$ glutamine homogeneously applied to the intact beech seedlingsoil systems showed that ${ }^{15} \mathrm{~N}$ but not ${ }^{13} \mathrm{C}$ was retrieved in mycorrhizal and plant tissues (Fig. 4.6, Tables 4.1, 4.2). This suggests that either uptake of intact glutamine was not significant under such realistic field conditions or glutamine derived $C$ was already subjected to respiration in the mycorrhizal mantle (Näsholm et al. 2009). These findings show the limitation of uptake capacity studies to explain actual in situ uptake of organic $\mathrm{N}$ in the presence of microbial competition. 
The $\mathrm{N}$ cycle in soil of the NW treatment was characterized by high nitrification rates (Fig. 4.6). In contrast, transfer to SW exposure resulted in a five-fold decline of gross nitrification and soil $\mathrm{NO}_{3}{ }^{-}$concentrations already in June (Fig. 4.6). Consequently, plant $\mathrm{NO}_{3}{ }^{-}$uptake was also reduced by a factor of five (Fig. 4.6), although mycorrhizal colonization of vital roots remained unaltered (Table 4.3). This suggests a tight link between soil water availability, gross nitrification, soil $\mathrm{NO}_{3}{ }^{-}$availability and $\mathrm{NO}_{3}{ }^{-}$uptake of beech seedlings. In conjunction with decreased $\mathrm{NH}_{4}{ }^{+}$uptake, this resulted in a significantly diminished plant $\mathrm{N}$ pool (Fig. 4.6). From June to August, plant biomass $\mathrm{N}$ increased significantly at NW but only marginally at SW under drought conditions (Fig. 4.6). Plant $\mathrm{N}$ uptake calculated from short-term ${ }^{15} \mathrm{NH}_{4}{ }^{+}$ and ${ }^{15} \mathrm{NO}_{3}{ }^{-}$tracing in June and August corresponded well with long-term $\mathrm{N}$ uptake calculated from the increment between June and August, with both approaches clearly showing a severely reduced $\mathrm{N}$ uptake for SW (Table 4.4). In August, rates of $\mathrm{N}$ turnover and plant uptake were generally less than in June both at NW and SW with similar but less pronounced climate change treatment effects on $\mathrm{N}$ cycling as observed in June (Fig. 4.6).



Figure 4.6: Gross $\mathrm{N}$ turnover rates $\left(\mathrm{mg} \mathrm{N} \mathrm{m}^{-2}\right.$ day $\left.^{-1}\right)(\mathrm{n}=8)$ and $\mathrm{N}$ pool sizes $\left(\mathrm{mg} \mathrm{N} \mathrm{m}^{-2}\right)(\mathrm{N}=48)$ in intact beech seedling-soil-mesocosms. Blue: NW exposure (control treatment); Red: SW exposure (climate change treatment). The June harvest represents the onset of the growing season after full development of leaves, while the August harvest was conducted in the middle of the growing season after 39 days of rainfall exclusion at SW. Gross rates of $\mathrm{N}$ turnover were calculated based on ${ }^{15} \mathrm{~N}$ tracing and pool dilution approaches following homogenous labelling of the intact soil with doublelabelled ${ }^{15} \mathrm{~N} /{ }^{13} \mathrm{C}$-glutamine, ${ }^{15} \mathrm{NH}_{4}^{+}$, or ${ }^{15} \mathrm{NO}_{3}^{-}$. Thickness of process arrows and nitrogen pool signatures is representative for respective turnover rates and pool sizes. Processes and pools significantly affected by the climate change treatment are indicated by bold letters with asterisks. Different indices show significant differences between June and August for a given treatment/exposure. 
Table 4.1: ${ }^{13} \mathrm{C}$ recovery $\left(\mathrm{mg}{ }^{13} \mathrm{C}\right.$ excess, and $\%$ of ${ }^{13} \mathrm{C}$ excess applied via glutamine) in plant (sum of fine roots, coarse roots, stem, leaves) for the single harvesting dates (month_time after glutamine labelling). No significant differences were observed between NW and SW.

\begin{tabular}{|c|c|c|c|c|c|c|}
\hline & $\begin{array}{l}\mathrm{NW} \\
\text { Mean } \\
{\left[\mathrm{mg}{ }^{13} \mathrm{C}\right.} \\
\text { excess] }\end{array}$ & SD & $\begin{array}{l}\% \text { of } \\
\text { applied } \\
{ }^{3} \mathrm{C} \text { excess }\end{array}$ & $\begin{array}{l}\text { SW } \\
\text { Mean } \\
{\left[\mathrm{mg}{ }^{13} \mathrm{C} \text { excess }\right]}\end{array}$ & SD & $\begin{array}{l}\% \text { of } \\
\text { applied } \\
{ }^{13} \mathrm{C} \text { excess }\end{array}$ \\
\hline June_6h & 0.0072 & 0.0078 & 0.4280 & -0.0028 & 0.0031 & -0.1657 \\
\hline June_48h & -0.0006 & 0.0032 & -0.0347 & -0.0127 & 0.0082 & -0.7547 \\
\hline August_6h & 0.0003 & 0.0056 & 0.0194 & -0.0007 & 0.0031 & -0.0419 \\
\hline August_48h & 0.0002 & 0.0048 & 0.0108 & 0.0005 & 0.0043 & 0.0322 \\
\hline September_3months & 0.0248 & 0.0086 & 1.4719 & 0.0117 & 0.0112 & 0.6929 \\
\hline
\end{tabular}

Table 4.2: ${ }^{13} \mathrm{C}$ enrichment (atom\%) in excess of natural abundance in mycorrhizal root tips harvested in June, August and September. No significant ${ }^{13} \mathrm{C}$ excess enrichment was observed in mycorrhiza within 48 hours after ${ }^{13} \mathrm{C}$ glutamine labelling.

\begin{tabular}{llllllll}
\hline $\begin{array}{l}\text { Harvest date_time } \\
\text { after }{ }^{13} \text { C labelling }\end{array}$ & NW & \multicolumn{3}{c}{ SW } & \multicolumn{3}{c}{ Two-Way-ANOVA } \\
& mean & SE & mean & SE & & p & F \\
\hline June_6h & -0.0004 & 0.0001 & -0.0006 & 0.0003 & Exposure & 0.924 & 0.009 \\
June_48h & -0.0002 & 0.0002 & -0.0014 & 0.0003 & Time & 0.000 & 6.178 \\
August_6h & 0.0005 & 0.0006 & 0.0000 & 0.0005 & Interactions & 0.003 & 4.602 \\
August_48h & -0.0010 & 0.0003 & -0.0007 & 0.0004 & & & \\
$\begin{array}{l}\text { September_3 } \\
\text { months }\end{array}$ & -0.0003 & 0.0005 & 0.0012 & 0.0002 & & & \\
\hline
\end{tabular}

Table 4.3: Percentage of vital root tips colonized with mycorrhizal fungi. No significant differences in mycorrhizal colonization rates were observed between the control treatment (NW exposure) and the climate change treatment (SW exposure).

\begin{tabular}{llllllll}
\hline & NW & & SW & \multicolumn{4}{c}{ Two-Way-ANOVA } \\
& mean & SE & mean & SE & & $\mathrm{p}$ & $\mathrm{F}$ \\
\hline June & 99.0 & 0.5 & 99.2 & 0.4 & Slope & 0.56 & 0.34 \\
August & 99.1 & 0.5 & 98.8 & 0.4 & Time & 0.08 & 2.51 \\
September & 99.7 & 0.1 & 99.9 & 0.1 & Interactions & 0.83 & 0.18 \\
\hline
\end{tabular}


Table 4.4: Total plant $\mathrm{N}$ uptake $\left(\mathrm{mg} \mathrm{N} \mathrm{m}^{-2}\right.$ day $^{-1}$ ) calculated (1) from the net increment of the mean plant $\mathrm{N}$ pool between June and August ( $\mathrm{n}=48 \mathrm{each}$ ), divided by the time span of 41 days between these harvesting dates, (2) from the sum of $\mathrm{NH}_{4}{ }^{+}$and $\mathrm{NO}_{3}{ }_{3}$ uptake rates calculated from short-term (6h) ${ }^{15} \mathrm{NH}_{4}{ }^{+}$and ${ }^{15} \mathrm{NO}_{3}{ }^{-}$tracing into plant biomass in June and August. Nitrogen uptake was always significantly smaller at SW exposure than at NW exposure $(p<0.05)$ for all approaches shown in the table.

\begin{tabular}{llll} 
& $\begin{array}{l}\mathrm{N} \text { increment June-August } \\
\text { (42 days) }\left(\mathrm{mg} \mathrm{N} \mathrm{m}^{-2} \text { day }^{-1}\right)\end{array}$ & $\begin{array}{l}\text { Short-term }{ }^{15} \mathrm{NH}_{4}{ }^{+} \text {and } \\
{ }^{15} \mathrm{NO}_{3} \text { tracing June }(\mathrm{mg} \mathrm{N} \\
\left.\mathrm{m}^{-2} \text { day }^{-1}\right)\end{array}$ & $\begin{array}{l}\text { Short-term }{ }^{15} \mathrm{NH}_{4}{ }^{+} \text {and } \\
{ }^{15} \mathrm{NO}_{3}^{-} \text {tracing August (mg } \\
\left.\mathrm{N} \mathrm{m}^{-2} \text { day }^{-1}\right)\end{array}$ \\
\hline $\mathrm{NW}$ & 10 & $35 \pm 7$ & $6 \pm 1.1$ \\
\hline SW & 3.4 & $9 \pm 1.6$ & $2.2 \pm 0.31$ \\
\hline
\end{tabular}

The observed effects of the climate change treatment on N processes (Table 4.5) in the plant-soil interface were confirmed by a range of supporting data. Concurrent analyses of microbial communities involved in selected processes of the $\mathrm{N}$ cycle revealed a pronounced reduction of ammonia oxidizing bacteria $(A O B)$ in bulk soil in June and September and in the rhizosphere in August (Fig. 4.8, Table 4.6). Gross nitrification rates were strongly positively correlated with the abundance of AOB in soil (Fig. 4.8). Therefore, the still significantly reduced number of gene copies of $\mathrm{AOB}$ at the end of the growing season in September (Fig. 4.8) suggests that the climate-change triggered mechanism of impaired nitrification with associated consequences for $\mathrm{NO}_{3}{ }^{-}$availability and uptake by beech is persistent. In contrast, effects on other functional groups of microbes involved in $\mathrm{N}$ turnover were not or not consistently observed (Table 4.6).

Reduced $\mathrm{N}$ uptake by beech seedlings of the climate change treatment is supported by persistently higher ${ }^{15} \mathrm{~N}$ enrichment in mycorrhizal root tips grown in NW exposure than in SW exposure (Table 4.7). Furthermore, long-term ${ }^{15} \mathrm{~N}$ recovery in beech seedlings as determined in September, i. e. three months after ${ }^{15} \mathrm{~N}$ labelling was persistently smaller at $\mathrm{SW}$ than at $\mathrm{NW}$ regardless of the ${ }^{15} \mathrm{~N}$ source provided (Fig. 4.9). Moreover, levels of $\mathrm{N}$-bearing metabolites in fine roots of beech seedlings of the climate change treatment were reduced (Fig. 4.7). Finally, above- and belowground biomass of beech seedlings were persistently smaller in SW than in NW beech-soil-mesocosms (Table 4.8).

Ammonification and soil $\mathrm{NH}_{4}{ }^{+}$levels were only marginally reduced in the climate change treatment (Fig. 4.6). This indicates that lower soil moisture accounted for attenuated nitrification through detraction of $\mathrm{AOB}$ metabolism and limitation of $\mathrm{N}$ substrate diffusion (Norton and Stark 2011). Soil moisture is the major environmental driver of in situ nitrification in Rendzic Leptosols with maximum nitrification at $65 \%$ of maximal water holding capacity (Dannenmann et al. 2006), i. e. the soil water levels frequently found at NW exposure (Fig. 4.7). A strong reduction of gross nitrification rates when soil moisture falls below this optimum is in line with our general understanding of nitrification (Norton and Stark 2011) as well as with earlier observations for Rendzic Leptosols in beech stands (Dannenmann et al. 2006). The strong sensitivity of the AOB community to climatic change conditions may be related to the fact that these microorganisms obligatorily depend on ammonia oxidation without metabolic alternatives. Thus, $\mathrm{NO}_{3}{ }^{-}$-dominated $\mathrm{N}$ nutrition of beech seedlings 
represents a major obstacle for beech performance under reduced soil water levels in marginal soil in a changing climate. This may also apply for adult beech growing on Rendzic Leptosols, which exhibit decreased maximum $\mathrm{NO}_{3}{ }^{-}$uptake capacity and basal stem area with declining soil water availability (Geßler et al. 2005).

Dynamic vegetation models so far focus on light and water as determinants of stand development and species competition in a changing climate. Our work shows that $\mathrm{N}$ dynamics is a critical component to be included in such models. Our data facilitate testing whether dynamic vegetation models coupled to process-oriented biogeochemical ecosystem models (Haas et al. 2013) can consider effects of climate change on beech performance more comprehensively, taking also into account $\mathrm{N}$ availability as mediated by soil microbes.

Table 4.5: Results of two-way ANOVA analysis testing the factors exposure (NW vs. SW), time (June/August/September) and the interaction of exposure and time on gross rates of $\mathrm{N}$ turnover in the plant-soil-microbe system and corresponding $\mathrm{N}$ pools. Numbers represent $\mathrm{P}$ (upper number, significant at $\mathrm{P}<0.05$ ) and Eta squared (lower number) as a measure of effect size

\begin{tabular}{llll} 
& Exposure & Time & Exposure x Time \\
\hline Ammonification & 0.223 & 0.064 & 0.24 \\
& 0.055 & 0.121 & 0.051 \\
\hline Nitrification & 0.01 & 0.119 & 0.213 \\
& 0.215 & 0.085 & 0.055 \\
\hline Micr. $\mathrm{NH}_{4}$ inmob. & 0.004 & 0.301 & 0.906 \\
& 0.26 & 0.038 & 0.001 \\
\hline Micr. $\mathrm{NO}_{3}$ immob. & $<0.001$ & $<0.001$ & 0.006 \\
& 0.367 & 0.433 & 0.243 \\
\hline Plant $\mathrm{NH}_{4}$ uptake & $<0.001$ & 0.002 & 0.633 \\
& 0.433 & 0.291 & 0.008 \\
\hline Plant $\mathrm{NO}_{3}$ uptake & 0.001 & $<0.001$ & 0.002 \\
& 0.335 & 0.494 & 0.29 \\
\hline DON pool & $<0.001$ & $<0.001$ & 0.003 \\
& 0.069 & 0.115 & 0.049 \\
\hline $\mathrm{NH}_{4}$ pool & 0.034 & $<0.001$ & 0.506 \\
& 0.024 & 0.205 & 0.007 \\
\hline $\mathrm{NO}_{3}$ pool & $<0.001$ & $<0.001$ & $<0.001$ \\
& 0.309 & 0.404 & 0.293 \\
\hline $\mathrm{Plant}$ pool & $<0.001$ & $<0.001$ & 0.517 \\
& 0.065 & 0.061 & 0.005 \\
\hline Micr. Biomass pool & 0.0067 & $<0.001$ & 0.022 \\
& 0.014 & 0.125 & 0.032 \\
\hline
\end{tabular}



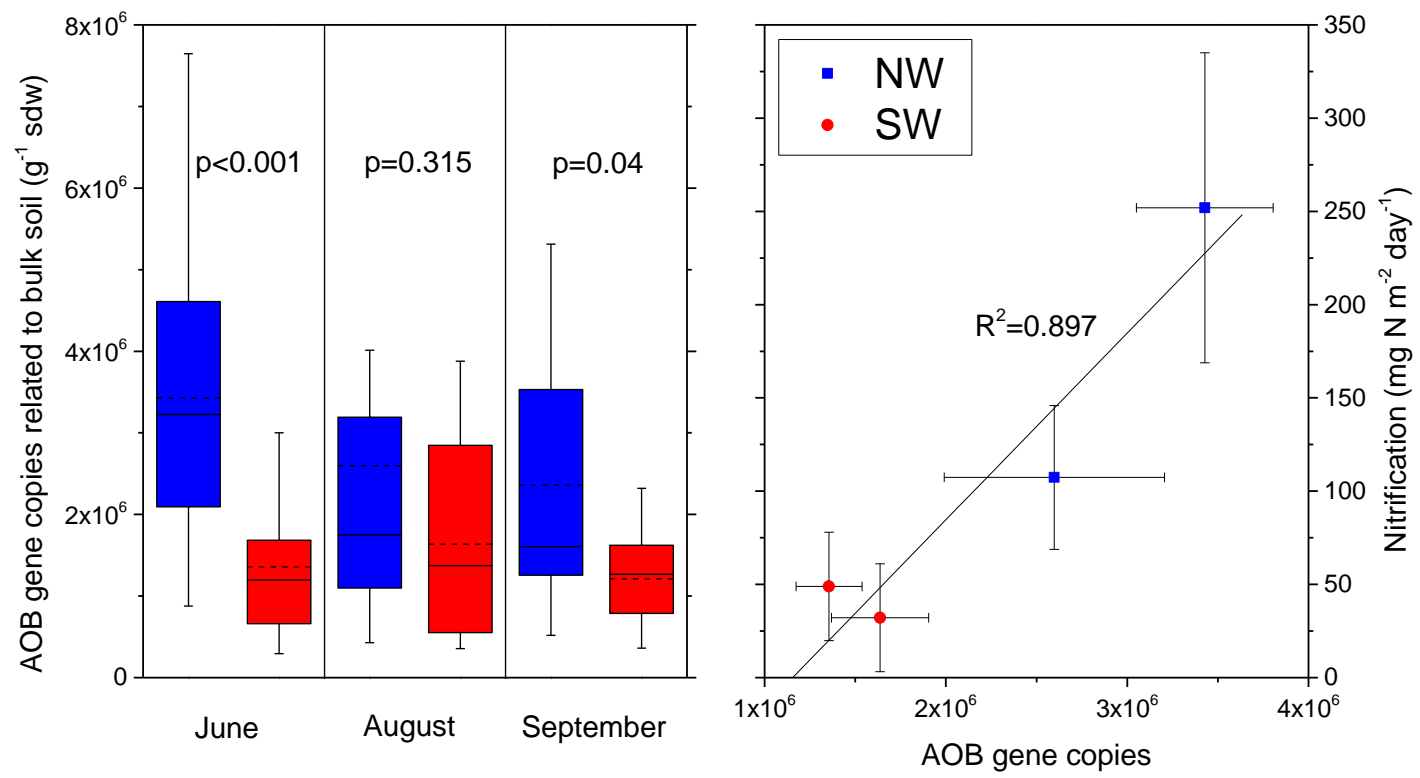

Figure 4.7: Ammonia oxidizing bacteria and nitrification rates. Abundance of genes encoding for ammonia monooxygenase of ammonia oxidizing bacteria in bulk soil (AOB, left panel) and relationships between $A O B$ gene abundance and gross rates of nitrification (right panel). Blue colour: control treatment (NW exposure). Red colour: climate change treatment (SW exposure).

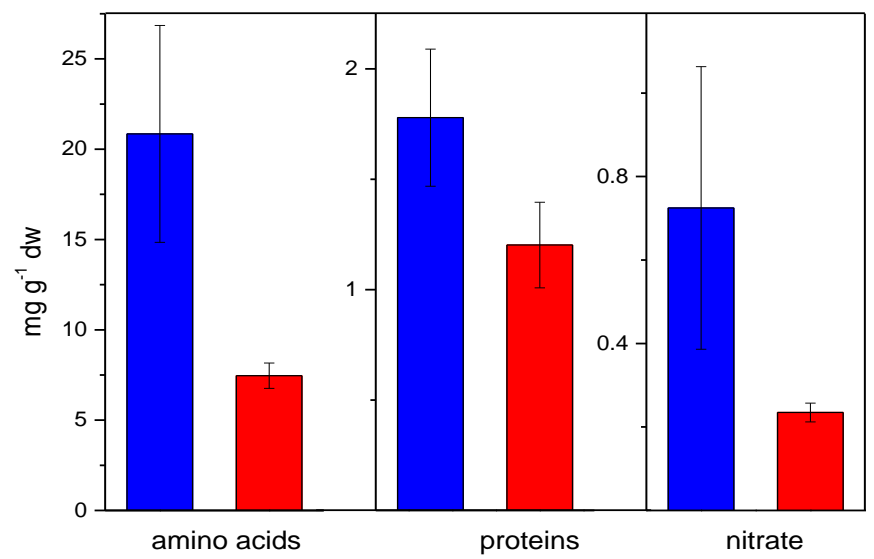

Figure 4.8: Metabolites (total amino acids, total soluble proteins, $\mathrm{NO}_{3}{ }^{-}$) extracted from fine roots of beech seedlings in June. Blue colour represents the control treatment (NW exposure), red colour represents the climate change treatment (SW exposure). Error bars denote standard errors of the mean. $\mathrm{n}=4$ per time and treatment. Amino acid and $\mathrm{NO}_{3}{ }^{-}$metabolite levels were significantly lower in trees of the climate change treatment. 


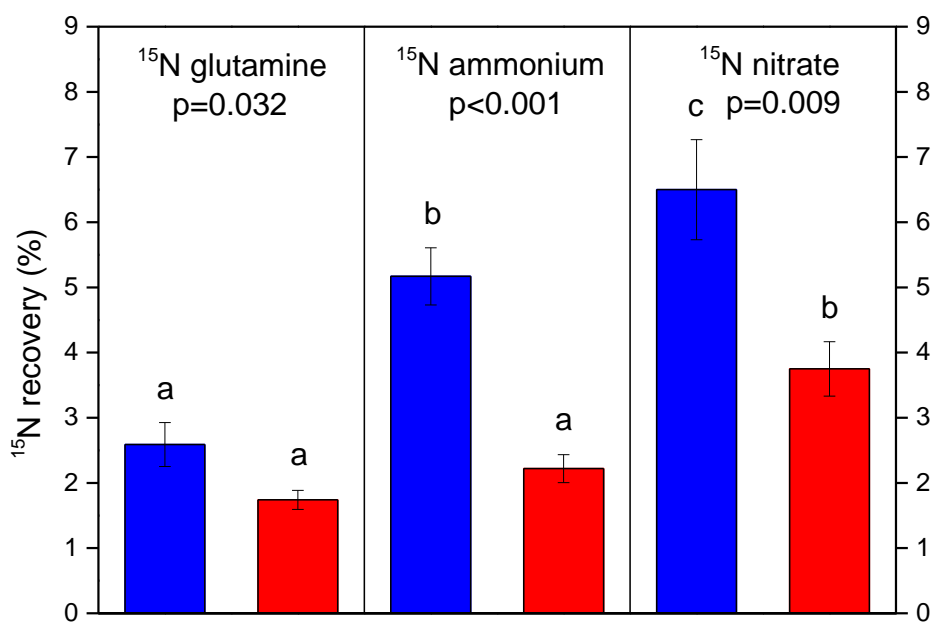

Figure 4.9: Long-term ${ }^{15} \mathrm{~N}$ recovery $(\mathrm{n}=8)$ in beech seedlings. ${ }^{15} \mathrm{~N}$ recovery (sum of fine roots, coarse roots, stem and leaves) was determined at the end of the growing season in September three months after ${ }^{15} \mathrm{~N}$ labelling with glutamine, $\mathrm{NH}_{4}^{+}$or $\mathrm{NO}_{3}^{-}$. Data indicate recovered \% of isotopic excess, i. e. after subtracting ${ }^{15} \mathrm{~N}$ natural abundance. Blue: NW exposure (control treatment); red: SW exposure (climate change treatment). ${ }^{15} \mathrm{~N}$ recovery was highest after nitrate labelling both for SW and NW as indicated by different indices. The climate change treatment always reduced ${ }^{15} \mathrm{~N}$ recovery, as indicated by $p<0.05$.

Table 4.6: Abundance of microbes involved in selected steps of the $\mathrm{N}$ cycle based on the quantification of marker genes. Nitrogen fixing microorganisms based on the nitrogenase gene nifH, archaeal and bacterial nitrifiers based on the ammonia monooxygenase gene amoA, denitrifiers based on the nitrite reductase genes nirK and nirS, as well as on the nitrous oxide reductase gene nos $Z$, and mineralising microorganisms based on the chitinase gene chiA and the metalloprotease gene apr. Significantly more gene copies in soil at NW exposure compared to SW exposure are highlighted in dark blue, while dark red is indicating significantly larger values at SW exposure. SD: standard deviation of the mean.

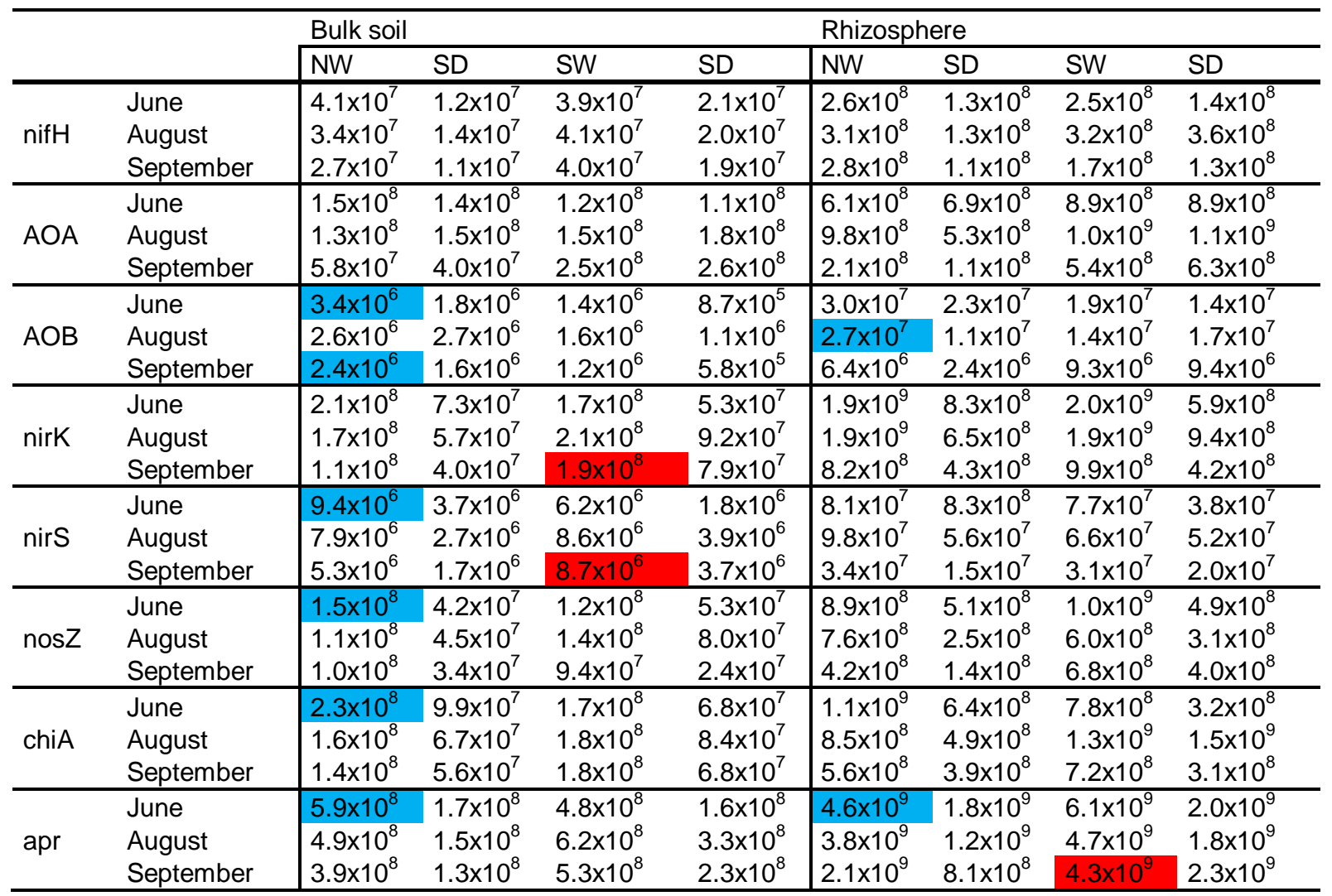


Table 4.7: ${ }^{15} \mathrm{~N}$ enrichment (atom\%) in excess of natural abundance in mycorrhizal root tips harvested in June and August (6 and 48 hours after isotope labelling each) and in September (3 months after isotope labelling). Significantly higher ${ }^{15} \mathrm{~N}$ enrichments at NW compared to SW is indicated by dark blue colour.

\begin{tabular}{llllllll}
\hline & NW & & SW & \multicolumn{4}{c}{ Two-Way-ANOVA } \\
N form & mean & SE & mean & SE & & $\mathrm{p}$ & $\mathrm{F}$ \\
\hline Glutamine & & & & & & & \\
June_6h & 0.0166 & 0.0022 & 0.0018 & 0.0003 & Exposure & 0.000 & 258 \\
June_48h & 0.0575 & 0.0166 & 0.0048 & 0.0030 & Time & 0.000 & 274.9 \\
August_6h & 0.0266 & 0.0113 & 0.0052 & 0.0014 & Interactions & 0.000 & 147.1 \\
August_48h & 0.0491 & 0.0157 & 0.0259 & 0.0111 & & & \\
September_3 & 0.0690 & 0.0076 & 0.0610 & 0.0085 & & & \\
months & & & & & & & \\
\hline Ammonium & & & & & & & \\
June_6h & 0.1586 & 0.0432 & 0.2157 & 0.0634 & Exposure & 0.049 & 4.1 \\
June_48h & 0.4825 & 0.0847 & 0.3964 & 0.0624 & Time & 0.000 & 11.6 \\
August_6h & 0.2371 & 0.0668 & 0.0833 & 0.0437 & Interactions & 0.534 & 0.8 \\
August_48h & 0.5961 & 0.1149 & 0.4223 & 0.1737 & & & \\
September_3 & 0.7681 & 0.1160 & 0.5523 & 0.0894 & & & \\
months & & & & & & & \\
\hline Nitrate & & & & & & & \\
June_6h & 0.0648 & 0.0252 & 0.0551 & 0.0136 & Exposure & 0.005 & 8.8 \\
June_48h & 0.2155 & 0.0546 & 0.1027 & 0.0327 & Time & 0.010 & 3.7 \\
August_6h & 0.0960 & 0.0264 & 0.0339 & 0.0085 & Interactions & 0.269 & 1.3 \\
August_48h & 0.2387 & 0.0790 & 0.0621 & 0.0161 & & & \\
September_3 & 0.1871 & 0.0445 & 0.1615 & 0.0448 & & & \\
months & & & & & & & \\
\hline
\end{tabular}

Table 4.8: Aboveground and belowground dry plant biomass $(\mathrm{mg})$ of beech seedlings for the three harvest dates. $n=48$ (June and August); $n=24$ (September). Significantly larger biomass at NW compared to SW tested for single harvest dates is indicated by dark blue colour.

\begin{tabular}{lllll}
\hline \multirow{2}{*}{ aboveground } & NW & June & August & September \\
& SW & $2325 \pm 134$ & $2590 \pm 155$ & $1919 \pm 93$ \\
belowground & NW & $1831 \pm 106$ & $2065 \pm 90$ & $1762 \pm 98$ \\
& SW & $1546 \pm 7$ & $1576 \pm 60$ & $2789 \pm 126$ \\
& & & $2421 \pm 155$ & $1955 \pm 96$ \\
\hline
\end{tabular}




\subsubsection{Implications for future forest management and ecosystem services}

Impaired microbial provision of bioavailable $\mathrm{N}$ may be a stressor for beech in addition to plant physiological limitations under reduced soil water availability, enhancing the drought sensitivity of beech under predicted climatic changes. The nutritional deficiency could be further exacerbated by enhanced $\mathrm{N}$ leaching after prolonged drought due to retarded stabilization of microbial $\mathrm{N}$ in organo-mineral associations (Bimüller et al. 2014).

By highlighting the relationships between drought, $\mathrm{N}$ cycling and beech $\mathrm{N}$ nutrition, our work provides pointers to developing mitigation options to increase forest resilience and adaptation potential in a changing climate. Nutritional limitations could be counteracted by fertilization to increase levels of bioavailable $\mathrm{N}$ in soil. However, trade-offs such as undesired rapid hydrological $\mathrm{NO}_{3}{ }^{-}$leaching (Bimüller et al. 2014) in the joint acquifers of limestone karst systems would need to be quantified. The associated risk for nitrous oxide losses may remain small due to high nitrous oxide reductase activity in such soils, converting nitrous oxide into harmless dinitrogen (Dannenmann et al. 2008). Another option is silvicultural reduction of stand density. This treatment increased soil water availability via increased throughfall and reduced competition for water in coniferous stands (Kohler et al. 2010). A further alternative is mixing beech stands with deep-rooting trees such as oak, which appears to improve water balance of soil and beech via hydraulic lift of water from deeper aquifers (Pretzsch et al. 2013), and thus may increase the resilience of forest stands to climate change conditions. In view of the long time spans needed to convert forests, there is an urgent need to consider alternative, more drought-robust tree species with higher $\mathrm{N}$ use efficiency for these ecosystems to maintain sustainable forest development and ecological services in Central European forests.

\subsection{Acknowledgements}

This work has been supported by the German Science Foundation (DFG) under the contract numbers DA 1217/2-1, KO 1035/41-1, PO 362/19-1, SCHL 446/11-1, RE 515/33-1; J.S. was financially supported by the Ministry of Science, Research and the Arts Baden-Württemberg and the European Social Fund.

We thank Rudi Meier (KIT/IMK-IFU-CSI), Jens Dyckmans (KOSI, Universität Göttingen) and Franz Buegger (Helmholtz Zentrum München) for isotope analyses, Thomas Klein for field work, Elisabeth Zumbusch for analysis of carbon and nitrogen in soil extracts and Allison Kolar for language correction. 


\subsection{Material and Methods}

\subsubsection{Maps intersection potential distribution of beech on calcareous sites}

The map (Fig. 4.1) is an intersect of a species distribution model for European beech (Hanewinkel et al. 2013b) based on maps of geology for Europe. For the species distribution model we used presence/absence information for European beech derived from the 'Data on Crown Condition of the systematic grid (16 x $16 \mathrm{~km}$ )' (Level I) from the 'International Cooperative Programme on Assessment and Monitoring of Air Pollution Effects on Forests' (ICPF) (Fischer et al. 2010) as response variable. This response was modelled using derivations of precipitation and temperature from the WorldClim-database as described in Hijmans et al. (2005). For the initial model we used nineteen bioclimatic variables included in the database and an additional calculated set of six bioclimatic variables consisting of the number of days per year with mean temperature above 5 degree Celsius, the yearly heat sum above 5 degree Celsius, mean temperature and precipitation sum in summer (defined as the months May to September) and annual and summer drought index according to O'Neill et al. (2007). For the projection under future conditions, we used output from the global circulation model HADCM3 (Gordon et al. 2000) driven by the SRES scenario A2 (IPCC 2000) until the year 2080, which was calibrated and statistically downscaled to 30-arcsecond tiles using the WorldClim data for 'current' conditions.

As a statistical model formulation we fitted a Generalized Linear Model (GLM) with logit link functions, (i.e. logistic regressions). We used second-order polynomials of the described bioclimatic variables on the link scales of the GLM and reduced the number of the predictors using the sum of the adjusted deviances as a statistical measure. We calibrated the model by a stepwise selection checking for changes in the Bayesian Information Criterion (Schwarz 1978). The final five bioclimatic variables that entered the model in linear and quadratic form were: yearly sum of degree days above $5^{\circ} \mathrm{C}$, iso-thermality, drought index after O'Neill et al. (2007) over the year, sum of precipitation in the warmest quarter of the year and the precipitation of the most humid month. As the threshold value for presence or absence we used Cohen's Kappa (Cohen 1960).

A detailed description of the modelling approach, the choice and selection of the predictors and the database of the model used for this investigation can be found in Hanewinkel et al. (2013b). For a general overview on species distribution models for major tree species in Europe see also Hanewinkel et al. (2013).

Using the described model we produced two maps depicting the potential distribution of European beech under current climate (1950-2000) and for scenario A2 until the year 2080 and intersected these maps with maps of the geology of Europe (Asch 2003). In these European maps with a scale of 1: 5'000'000 we selected all pixels that were assigned to formations including calcareous, limestone or other basic substrates. For Germany where no detailed information on the substrate was displayed in the European map, we used the 1:1'000'000 map for the Geology of Germany (BGR 1993). For areas in Europe such as Poland, Estonia, Lithuania and Latvia that did not display information on Geological map of Europe as well, we examined whether European beech plays a significant role in the species distribution. As this was not the case for both time periods we excluded these parts of 
Europe from the analysis. The intersected maps were created using standard overlay functions.

\subsubsection{Description of experimental study site}

The field study was conducted in a 90 years-old beech forest (Dannenmann et al. 2009) located at an altitude of $800 \mathrm{~m}$ above sea level in the "Schwäbische Alb", a low mountain range in Southern Germany $\left(8^{\circ} 45^{\prime} \mathrm{E} ; 47^{\circ} 59^{\prime} \mathrm{N}\right)$. Mean annual air temperature is approximately $6.5^{\circ} \mathrm{C}$ and the average annual rainfall amounts to $854 \mathrm{~mm}$ (1961-1990). Atmospheric $\mathrm{N}$ input at the study site is comparably small with less than $10 \mathrm{~kg} \mathrm{~N} \mathrm{ha}^{-1}$ year (Dannenmann et al. 2008). The present experiment was conducted at approximately $1 \mathrm{~km}$ distance to the long-term ecological beech forest research site of the Tuttlingen research station ("NE" or "N" site) (Mayer et al. 2002; Geßler et al. 2004; Dannenmann et al. 2006, 2008, 2009; Simon et al. 2011; Guo et al. 2013). The clay-rich soil is classified as Rendzic Leptosol (Skeletic) according to the International Union of Soil Sciences Working Group WRB (2007) derived from horizontally bedded limestone and marls. Soil profiles are shallow followed by weathered parent rock containing $>45 \%$ gravel and stones. Due to nutrient poor soils and low atmospheric $\mathrm{N}$ input, soil $\mathrm{N}$ cycling is characterized by competitive partitioning of $\mathrm{N}$ between beech and associated mycorrhiza vs. free living soil microorganisms (Dannenmann et al. 2009; Simon et al. 2011).

\subsubsection{Experimental design}

The climate change treatment was established using a space for time approach and combined with isotope-based process studies (Fig. 4.2). We used exposure-induced model ecosystems located on opposing slopes of a narrow valley, a cool-moist (NW aspect, representing "current climate conditions") and a warm-dry local climate (SW aspect, representing "future climate conditions") with a distance of less than $1 \mathrm{~km}$. Microclimate at SW exposure is characterized by increased daily maximum of air and topsoil temperatures and thus reduced water availability (Geßler et al. 2004). Therefore, the SW aspect is considered to be a model ecosystem with local climatic patterns equalling the climatic conditions predicted for coming decades (Geßler et al. 2005). After full development of leaves, photosynthetic active radiation levels at the forest floor are mainly regulated by the canopy rather than by slope exposure (Mayer et al. 2002). After transfer of intact beech seedling-soil-microbe mesocosms either within NW or to SW in summer 2010, they were left undisturbed for an equilibration period of one year. Subsequently short-term-isotope-tracingbased process studies were conducted via homogenous ${ }^{15} \mathrm{~N}$ labelling followed by destructive harvests to simultaneously quantify all relevant gross $\mathrm{N}$ turnover processes in the plant-soilmicrobe system in June and August 2011. Long-term (>3 month) isotope recovery in the plant-soil-N pools was investigated in a third, final harvest in September 2011 (Fig. 4.2). At all three harvest dates, supporting soil, microbial, mycorrhizal and plant parameters as well as gene abundance of $\mathrm{N}$ cycle genes in soil were determined as described in the following sections.

\subsubsection{Transfer of intact beech-soil-microbe systems to simulate climate change}

The experiment was implemented in July 2010 by transferring intact beech-soil-mesocosms within the NW slope (control, "present climate conditions") and to the SW slope (climate change treatment, "future climate conditions"). Transfer was conducted within one week in absence of precipitation. The simulated climate change conditions at the SW slope were 
intensified through a temporal (June 27, 2011 - August 05, 2011) rain sheltering roof approximately $1 \mathrm{~m}$ above ground level to allow free air flow (Fig. 4.2, Fig. 4.4).

Identification of coring spots for beech-soil-mesocosms was based on two steps. First, a suitable sampling area of 50 * $50 \mathrm{~m}$ with identical slope $\left(18^{\circ}\right)$ and similar soil profile was identified. In this area typical for the entire NW slope, finer grained soil (Ah horizon) was only found in the uppermost $15-20 \mathrm{~cm}$ (i. e. the main rooting zone of beech natural regeneration). There was a sharp transition between this almost gravel-free clay-rich finer grained soil and the deeper gravel-dominated periglacial layers which were not suitable for coring.

Subsequently, beech natural regeneration trees of 2.2-2.5 mm stem diameter and $30-40 \mathrm{~cm}$ height were selected and marked in this area. Custom-made stainless steel cylinders (height $150 \mathrm{~mm}$, outer diameter $168 \mathrm{~mm}$, sharp edge at bottom, wall thickness $2 \mathrm{~mm}$, open at bottom and top) were manually driven into the soil with the selected beech seedling growing in the centre. The litter layer was preserved and contained in the cylinders during coring. A custom-made extension tool fitting to the stainless steel cylinders facilitated coring under avoidance of damage to the aboveground part of the plant. Pre-tests showed that the entire root system of beech seedlings of this size fitted well to the embraced volume of the used steel cylinders. After coring, the cylinders containing an intact beech-soil-mesocosm were carefully excavated under preservation of an even ending at the bottom. Only beech-soilmesocosms without visible damage or cut of the beech roots were used. Excavated beechsoil-mesocosms were immediately reburied vertically either within NW or after transfer to $\mathrm{SW}$. The incubation areas were in fenced zones of $400 \mathrm{~m}^{2}$ either in immediate vicinity to the sampling area (NW) or at the SW slope in $1 \mathrm{~km}$ distance characterized by the same inclination. Both NW and SW incubation areas showed closed canopy and only beech trees were present at a distance of $50 \mathrm{~m}$. While reburying beech-soil-mesocosms, extreme care was taken to create a realistic transition between the bottom of the soil cores and the ambient soil. For this purpose, beech-soil-mesocosms were placed vertically in holes with a 5 $\mathrm{cm}$ thick horizontal bed made of homogenized NW soil and subsequently gently hammered down $2 \mathrm{~cm}$ at the new position. Finally, continuous contact between the litter layer on the transferred beech-soil-mesocosms and the surrounding litter layer at the new position was established. After transfer, all reburied intact beech-soil-mesocosms at both sites were irrigated with $500 \mathrm{ml}$ of water over a period of two hours to avoid drying or death of enclosed beech seedlings following transfer. The amount of water corresponded to a precipitation event of $23.7 \mathrm{I} \mathrm{m}^{-2}$, i. e. a typical summer convective rainfall event. The survival rate of transferred beech seedlings was $97 \%$. After transfer, the beech-soil-mesocosms were preincubated in situ for almost an entire year to allow adaptation to the new environmental surrounding and exposure to the climate conditions at NW and SW, respectively.

Additionally, 10 further beech-soil-mesocosms were transferred in special stainless steel cylinders (5 within the NW slope, 5 to the SW slope) to monitor soil temperature and soil moisture in $5 \mathrm{~cm}$ depth ( $\mathrm{n}=5$ each slope) using horizontally installed combined soil moisture/temperature probes (DECAGON EC-5, Decagon Devices, Inc., Pullman, USA) with an hourly temporal resolution. 


\subsubsection{Isotope labelling}

In order to facilitate the simultaneous quantification of gross rates of all major $\mathrm{N}$ turnover processes in the beech-soil-microbe system, the intact soil-root-mesocosms were labelled with either ${ }^{15} \mathrm{~N} /{ }^{13} \mathrm{C}$-enriched glutamine, ${ }^{15} \mathrm{NH}_{4}{ }^{+}$or ${ }^{15} \mathrm{NO}_{3}{ }^{-}$. To enable homogenous distribution of isotopes in the root-soil system, we applied an isotope injection method developed for large soil cores ${ }^{20}$ and optimized and adapted it for the Tuttlingen soil. For this purpose, we conducted pre-experiments in March 2011 using Brilliant Blue FCF colour dye instead of ${ }^{15} \mathrm{~N}$ enriched label solution. Various injection patterns and depths, numbers of injections per mesocosm and solution volumes per single injection were tested to comply with the opposing requirements (1) homogenous 3-dimensional distribution of label solution in the soil-rootsystem, (2) minimization of injected liquid to minimize label artefacts such as stimulation of $\mathrm{N}$ turnover, and (3) minimal leakage of label solution at the bottom of the beech-soilmesocosms. In this pre-experiment, mesocosms were harvested one day after dye application by removing soil stepwise from bottom to top in layers of $2 \mathrm{~cm}$. The distribution of the colour dye in the soil was monitored visually. Outflow at the bottom of the labelled beechsoil-mesocosms was examined by storing the beech-soil-mesocosms on white paper sheets. To inject dye - and later ${ }^{15} \mathrm{~N}$ - solution - we used custom-made stainless steel side port cannulas with lasered depth check marks. In this labelling optimization experiment the following setup facilitated homogenous colour dye distribution with only minimal leakage: 16 single amounts of $3 \mathrm{ml}$ solution each were injected into the soil-mesocosms to a depth of 1 and $3 \mathrm{~cm}$ each, and another 8 injections of $3 \mathrm{ml}$ each to a depth of $6 \mathrm{~cm}$. Additionally, $10 \mathrm{ml}$ of ${ }^{15} \mathrm{~N}$-labelled solution were homogenously spread on top of the soil surface. Hence, the total amount of added label solution was $130 \mathrm{ml}$, applied to on average $2.3 \mathrm{~kg}$ dry soil contained in the beech-soil-mesocosms. Paper calibres indicating injection patterns and depths were constructed to fit onto the stainless steel cylinders in order to ensure reproducible labelling. Before ${ }^{15} \mathrm{~N}$-labelling, the litter layer was removed from the top of the soil surface and later replaced. An earlier study showed that the litter layer is of very minor significance for $\mathrm{N}$ nutrition of beech natural regeneration (Guo et al. 2013).

Labelling of beech-soil-microbe systems took place on June 22, 2011 (72 beech-soilmesocosms at NW and SW each), to (1) compare gross $\mathrm{N}$ turnover between ambient conditions at SW and NW exposure via short-term ${ }^{15} \mathrm{~N}$ tracing based on full destructive harvests six hours and 48 hours after labelling, and (2) to investigate long-term ${ }^{15} \mathrm{~N}$ recovery at the end of growing season. A second labelling campaign took place August 2 (48 beechsoil-mesocosms at NW and SW each), followed by the same short-term isotope tracing approaches six and 48 hours after labelling. The August labelling/harvest cycle allowed to compare gross $\mathrm{N}$ turnover between ambient conditions at NW and roof-intensified drought (39 days) conditions at SW. Labelling was conducted simultaneously at NW and SW by a well-trained team of 10 persons starting at 5:00 am and took 3 hours (June) and 2 hours (August).

The label solution always contained all three $\mathrm{N}$ compounds used in this experiment, i. e. $\mathrm{NH}_{4}{ }^{+}, \mathrm{NO}_{3}{ }^{-}$and glutamine, and depending on the labelling treatment, either $\mathrm{NH}_{4}{ }^{+}, \mathrm{NO}_{3}{ }^{-}$or glutamine was isotopically enriched $\left(50\right.$ atom $\%{ }^{15} \mathrm{~N}$, and additionally 50 atom $\%{ }^{13} \mathrm{C}$ for glutamine). All $\mathrm{C}$ and $\mathrm{N}$ atoms of glutamine used for labelling were isotopically enriched. Glutamine was chosen as an organic N compound because earlier studies showed high glutamine uptake capacities of beech seedlings and adult beech trees at this site 
(Dannenmann et al. 2009; Simon et al. 2011). The amount of $\mathrm{N}$ added via label solution equalled to $3.5 \mathrm{mg} \mathrm{NH}_{4}{ }^{+}-\mathrm{N} \mathrm{kg}^{-1}$ soil dry weight (sdw), $3.5 \mathrm{mg} \mathrm{NO}_{3}{ }^{-} \mathrm{N} \mathrm{kg}^{-1} \mathrm{sdw}$, and $0.7 \mathrm{mg}$ glutamine- $\mathrm{N} \mathrm{kg}^{-1}$ sdw. Soil $\mathrm{NH}_{4}{ }^{+}$background concentrations in unlabeled soil were hardly different between NW and SW. However, soil background soil $\mathrm{NO}_{3}$ concentrations were generally much smaller at $\mathrm{SW}$ than at NW. Therefore, the ratio of added $\mathrm{NO}_{3}{ }^{-} \mathrm{N}$ via label solution to background soil $\mathrm{NO}_{3}{ }^{-}$was larger for $\mathrm{SW}$ than for NW. In June, $\mathrm{N}$ added via label solution equalled to $76 \%$ and $80 \%$ of ambient $\mathrm{NH}_{4}{ }^{+}$concentrations and $35 \%$ and $78 \%$ of ambient $\mathrm{NO}_{3}{ }^{-}$concentrations at NW and SW, respectively. In August, this equalled $84 \%$ and $114 \%$ of ambient soil $\mathrm{NH}_{4}{ }^{+}$concentrations. However, $\mathrm{NO}_{3}{ }^{-}$levels were extremely low in particular at SW, so that added label equalled to $211 \%$ and $762 \%$ of ambient $\mathrm{NO}_{3}$ concentrations at NW and SW, respectively.

Hence, several-fold reduced soil $\mathrm{NO}_{3}{ }^{-}$levels were observed both in unlabelled mesocosms and in labelled mesocosms of the climate change treatment. The amount of added ${ }^{15} \mathrm{~N}$ excess was $1.7 \mathrm{mg} \mathrm{N} \mathrm{kg}^{-1} \mathrm{sdw}$ for the $\mathrm{NH}_{4}{ }^{+}$and $\mathrm{NO}_{3}{ }^{-}$labelling variants and $0.34 \mathrm{mg} \mathrm{N} \mathrm{kg}^{-1}$ sdw for the glutamine labelling variants. Mean total ${ }^{15} \mathrm{~N}$ isotope recovery six hours after labelling in soil and plant was $73 \pm 6 \%$ across all exposures, harvesting dates and labelling treatments.

\subsubsection{Beech-soil-mesocosm harvest and sample preparation}

Eight intact beech-soil-mesocosms were harvested for each of the three $\mathrm{N}$-compound labelling treatments and each of the two slopes (NW exposure, control treatment and SW exposure, climate change treatment). Such harvesting of 48 beech-soil-mesocosms took place for the first labelling/harvest cycle on June 22, 2011 (6 hours after labelling) and June 24, 2011 (48 hours after the labelling). The same approach was repeated on August 2 (6 hours after labelling) and August 4 (48 hours after labelling) in order to compare NW conditions with intensified drought at SW. A final harvest of beech-soil-mesocosms was conducted on September 27, 2011, i. e. > 3 months after isotope labelling to investigate longterm ${ }^{15} \mathrm{~N}$ recovery). The harvest times were chosen based on earlier experience with isotope dynamics in this soil and correspond well to time spans generally recommended to investigate soil $\mathrm{N}$ turnover and $\mathrm{N}$ uptake (Näsholm et al. 2009). The harvests on June 22-24, August 2-4 and September 27 were accompanied by additional harvests of unlabelled beech-soil-mesocosms to analyze ambient background inorganic $\mathrm{N}$ concentrations and isotopic natural abundance of investigated pools with 4-8 replicates per exposure.

For harvesting, beech-soil-mesocosms were excavated under maintenance of an even ending at the bottom and entirely harvested within two hours after excavation. The beech seedling was cut and further processed as described below. The remaining soil/root system was carefully separated by hand into soil, gravel, dead coarse organic material and living fine and coarse roots. Additionally, mycorrhizal root tips and a subsample of rhizosphere soil (defined as soil adhering to root after vigorous shaking) were sampled and further processed as described below.

The soil contained in each mesocosm was immediately homogenized by manual mixing for 10 minutes to assure full mixing to a homogeneous sample. All soil extraction steps for analysis of $\mathrm{N}$ compounds and their ${ }^{15} \mathrm{~N}$ enrichment in soil were immediately conducted during harvest in the field lab with field fresh soil (see below). A subsample of ca. $100 \mathrm{~g}$ soil was air 
dried. For nucleic acid analysis, other subsamples of bulk soil as well as the rhizosphere soil were immediately frozen at $-80^{\circ} \mathrm{C}$.

Fresh weight of the entire soil contained in the beech-soil-mesocsoms and the weight of the stainless steel cylinders were recorded. Gravimetric soil water content was determined with a subsample of approximately $400-500 \mathrm{~g}$ of soil by drying at $105^{\circ} \mathrm{C}$ until constant weight.

During each harvest, beech seedlings were carefully removed from mesocosms and separated into leaves, stems, coarse ( $>2 \mathrm{~mm}$ diameter) and fine roots ( $<2 \mathrm{~mm}$ diameter). Remaining adhering small soil was carefully washed from the roots and dried. The fresh weight of each plant tissue was determined. Samples were dried at $60^{\circ} \mathrm{C}$ until constant weight. After determination of the fresh weight, fine root samples were separated into two parts for subsequent analyses: one part for ectomycorrhizal analyses was wrapped in wet tissue and stored in plastic bags at $4^{\circ} \mathrm{C}$ until return to the laboratory, the second part was dried at $60^{\circ} \mathrm{C}$ for 2 days for later EA-IRMS analyses. For biochemical analyses of $\mathrm{N}$ metabolites in fine roots, additional samples were taken from unlabelled beech-soilmesocosms on June 22 and shock-frozen in liquid $\mathrm{N}$ until sample analyses to avoid degradation of the metabolites.

\subsubsection{Total organic carbon (C), total $\mathrm{C}$ and $\mathrm{N}$ and $\delta^{15} \mathrm{~N}$ in bulk soil}

Soil samples were immediately frozen and freeze-dried after harvest. After removing roots and gravel using tweezers, bulk soil samples were finely ground. Determination of total soil $\mathrm{C}, \mathrm{N}$ and $\delta^{15} \mathrm{~N}$ was performed in duplicate for every sample with an isotope ratio mass spectrometer (Delta V, Thermo Electron Corporation, Dreieich, Germany) coupled to an elemental analyzer (Euro EA, Eurovector, Milan, Italy) at the Helmholtz Zentrum München, German Research Center for Environmental Health, Institute of Soil Ecology in Neuherberg. The ${ }^{15} \mathrm{~N}$ atom\% excess enrichment was calculated by subtracting natural abundance values gained by the unlabelled mesocosms from the values obtained of the labelled soil mesocosms.

\subsubsection{Analysis of extractable soil $\mathrm{N}$ pools}

A representative subsample of $100 \mathrm{~g}$ of homogenized soil out of every harvested beech-soilmesocosm was immediately extracted during the harvests in the field with $0.5 \mathrm{M} \mathrm{K}_{2} \mathrm{SO}_{4}$ at a soil:solution ratio of 1:1.5. Addition of $\mathrm{K}_{2} \mathrm{SO}_{4}$ solution was followed by 1 hour of shaking at 240 rotations per minute. After shaking, extracts were vacuum filtered using pumps and glass fibre filters (Dannenmann et al. 2009). Subsamples of the extract were transferred into different tubes and immediately frozen in the field for later analysis of (1) total organic $\mathrm{C}$ and total $\mathrm{N}$ concentrations, (2) $\mathrm{NH}_{4}{ }^{+}$and $\mathrm{NO}_{3}{ }^{-}$concentrations, (3) ${ }^{15} \mathrm{~N}$ enrichment in $\mathrm{NH}_{4}{ }^{+}, \mathrm{NO}_{3}{ }^{-}$ and dissolved organic $\mathrm{N}$ (DON), and (4) ${ }^{15} \mathrm{~N}$ enrichment in total dissolved (organic + mineral) N.

A second soil subsample was not immediately extracted, but first underwent a chloroformfumigation over 24 hours as described in detail in an earlier publication (Dannenmann et al. 2006) and was extracted afterwards as described above with subsequent freezing of the extract for later analysis of (1) total $\mathrm{N}$ (mineral + organic) and (2) $\delta^{15} \mathrm{~N}$ in total $\mathrm{N}$. 
Ammonium and $\mathrm{NO}_{3}{ }^{-}$concentrations in extracts were analyzed colourimetrically by a commercial laboratory (Dr. Janssen, Gillersheim, Germany) (Dannenmann et al. 2009). Total organic $\mathrm{C}(\mathrm{TOC})$ and total $\mathrm{N}$ (TN) in extracts were quantified using an Infrared TOC analyzer with a coupled chemoluminescence-based total N module (DIMATEC GmbH, Germany) (Dannenmann et al. 2009). Dissolved organic $\mathrm{N}$ was calculated as the difference between total $\mathrm{N}$ and mineral $\mathrm{N}$ in extracts.

The ${ }^{15} \mathrm{~N}$ enrichment in soil $\mathrm{NH}_{4}{ }^{+}, \mathrm{NO}_{3}{ }^{-}$and $\mathrm{DON}$ was quantified by sequential diffusion steps, based on conversion of the target compounds into $\mathrm{NH}_{4}{ }^{+}, \mathrm{pH}$ increase to induce volatilization as $\mathrm{NH}_{3}$, and subsequent trapping of $\mathrm{NH}_{3}$ on acid traps prepared for isotope ratio mass spectrometry (IRMS) at the Center of Stable Isotopes of KIT-IMK-IFU as described in detail in earlier publications (Wu et al. 2011; Guo et al. 2013).

Microbial biomass $\mathrm{N}$ and ${ }^{15} \mathrm{~N}$ were quantified following the chloroform-fumigation extraction approach as described in detail in earlier publications (Wu et al. 2011; Guo et al. 2013). No conversion factors $\left(\mathrm{k}_{\mathrm{EN}}\right)$ were used to render estimates of rather the active part of microbial biomass and newly immobilized N (Guo et al. 2013).

Total non-extractable soil $\mathrm{N}$ and the respective ${ }^{15} \mathrm{~N}$ recovery were calculated as the difference between total soil $\mathrm{N}$ and all extractable $\mathrm{N}$ compounds (i. e. $\mathrm{NH}_{4}{ }^{+}, \mathrm{NO}_{3}{ }^{-}, \mathrm{DON}$ and microbial biomass $\mathrm{N}$ ).

\subsubsection{Analysis of ectomycorrhizal colonization and stable isotope analysis of ectomycorrhizal root tips}

During harvest in the field laboratory, precleaned fine root samples (see 2.4) were placed in tap water filled petri dishes under a dissecting microscope (Stemi SV 11; Zeiss, Jena Germany) and were thoroughly cleaned from adhering soil particles using fine forceps.

Back in the laboratory randomly chosen, $2-3 \mathrm{~cm}$ long parts of the root system were used for examination under a dissecting microscope (205 FA; Leica, Wetzlar, Germany) and processed according to the method of Pena et al. (Pena et al. 2010). In each sample, 300 vital root tips were counted recording simultaneously the number of dead root tips. Occasionally, samples contained less than 300 living root tips. The root tips were classified as mycorrhizal, non mycorrhizal and dry root tips.

Samples of ectomycorrhizal root tips were collected for isotope measurements. For determination of $\mathrm{C}$ and $\mathrm{N}$ content as well as ${ }^{15} \mathrm{~N}$ and ${ }^{13} \mathrm{C}$ enrichment, root tips were dried for three days at $60^{\circ} \mathrm{C} .1-5 \mathrm{mg}$ of root tip material was weighted in $5 \times 9 \mathrm{~mm}$ tin capsules (IVA Analysetechnik, Meerbusch, Germany) with a micro balance (Supermicro S4; Sartorius, Göttingen, Germany). Measurements were conducted at the service unit KOSI (Kompetenzzentrum für Stabile Isotope, University Göttingen, Germany) using an isotope ratio mass spectrometer (IRMS Delta Plus, Finnigan MAT, Bremen, Germany) coupled via interface (Conflo III, Finnigan MAT, Bremen, Germany) to an elemental analyzer (NA1110, CE-Instruments, Rodano, Milano, Italy). Acet anilide was used as standard and IAEA N1 $\left(\delta^{15}\right.$ Nair $0.4 \%$ ) und $\mathrm{N}_{2}\left(\delta^{15} \mathrm{Nair} 20.3 \%\right.$ ) for $\mathrm{N}$ calibrations and IAEA $600\left(\delta^{13} \mathrm{CVPDB}-27.7\right.$ $\%$ ) for $\mathrm{C}$ calibrations. 


\subsubsection{Total $\mathrm{N}$ and $\mathrm{C}$ and $\delta^{15} \mathrm{~N}$ and $\delta^{13} \mathrm{C}$ in beech tissues}

To determine total $\mathrm{N}$, as well $\delta^{15} \mathrm{~N}$ and $\delta^{13} \mathrm{C}$ notation in plant tissues, oven-dried $\left(48 \mathrm{~h}, 60^{\circ} \mathrm{C}\right)$ samples were ground to a fine powder using a ball mill (Retsch MM 100, Retsch GmbH, Haan, Germany) for leaves and fine roots, and liquid $\mathrm{N}$ for stems and coarse roots. Aliquots of 1.0-2.5 mg for each tissue were weighed into tin capsules (IVA Analysentechnik, Meerbusch, Germany). Samples were analysed using an elemental analyser (Vario EL, elementar Analysensysteme $\mathrm{GmbH}$, Hanau, Germany) coupled to an isotope ratio mass spectrometer (Delta Plus, Thermo Finnigen MAT GmbH, Bremen, Germany). Working standards (glutamic acid), calibrated against primary standards USGS 40 (glutamic acid $\left.\delta^{13} \mathrm{CPDB}=-26.39\right)$ and USGS $41\left(\delta^{13} \mathrm{CPDB}=37.63\right)$ for $\delta^{13} \mathrm{C}$ and USGS $41\left(\delta^{15} \mathrm{~N}_{\text {air }}=47.600\right)$ for $\delta^{15} \mathrm{~N}$, were analyzed after every twelfth sample to enable correction of drift of isotopic analyses over time if required.

\subsubsection{Metabolites: quantification total soluble protein, total amino acids and $\mathrm{NO}_{3}{ }^{-}$in the fine roots of beech seedlings}

For biochemical analyses of $\mathrm{N}$ metabolites in the fine roots of beech seedlings, only fine roots from unlabelled samples were used from three time points (see above). Total amino acids in the fine roots were extracted (Winter et al. 1992) from frozen homogenous fine root material ( 50mg) in $1 \mathrm{~mL}$ methanol:chloroform (3.5:1.5, v:v) and $0.2 \mathrm{~mL}$ buffer $(\mathrm{pH} 7.0)$ containing $20 \mathrm{mM}$ Hepes, $5 \mathrm{mM}$ EGTA and $10 \mathrm{mM} \mathrm{NaF}$. Total amino acid concentration was quantified photometrically (Beckman Coulter Inc., Fullerton, CA, USA) at $570 \mathrm{~nm}$ as described by $\mathrm{Li}$ et al. (2005) using the colour reaction with ninhydrin reagent. Glutamine was used as a standard (Sigma, Hamburg, Germany). Total soluble proteins were extracted from ( 50mg) frozen and ground fine root material in $1 \mathrm{~mL}$ buffer $(1 \mathrm{mM}$ EDTA, $50 \mathrm{mM}$ Tris $-\mathrm{HCl}$ (pH 8.0), $1 \mathrm{mM}$ phenylmethylsulfonyl fluoride (PMSF), 15\% glycerol (v:v), $5 \mathrm{mM}$ dithiothreitol (DTT) and $0.1 \%$ Triton-X 100) as described in detail earlier (Dannenmann et al. 2009). Concentrations of total soluble protein were quantified photometrically at $595 \mathrm{~nm}$ using Bradford reagent (Ameresco Inc., Solon, Ohio, USA) in a UV-DU650 spectrophotometer (Beckman Coulter Inc., Fullerton, CA, USA). Bovine serum albumine (BSA A-6918, Sigma Aldrich Chemie $\mathrm{GmbH}$, Taufkirchen, Germany) was used as standard. Nitrate levels were extracted from c. $50 \mathrm{mg}$ tissue in $0.1 \mathrm{~g}$ washed polyvinylpyrrolidone (PVP Sigma-Aldrich Inc., Steinheim, Germany) (Dannenmann et al. 2009). Nitrate concentration was determined using an ion chromatograph (DX 120, Dionex, Idstein, Germany) combined with an autosampler (AS 3500, Thermo Separation Products, Piscataway, USA) and equipped with the PeakNet software package (version 4.3, Dionex, Idstein, Germany). Nitrate, phosphate, and sulphate were used as standards.

\subsubsection{Nucleic acid extraction from bulk soil and rhizosphere}

DNA was extracted from $0.4 \mathrm{~g}$ bulk soil and $0.1 \mathrm{~g}$ rhizosphere soil, respectively, using the FastDNA ${ }^{\mathrm{TM}}$ SPIN Kit for Soil (MP Biomedicals, Heidelberg, Germany) and the Precellys 24 Instrument (Bertin Technologies, Montigny-le-Bretonneux, France). Quantity and quality of the extracted DNA were checked with a spectrophotometer (Nanodrop, PeqLab, Erlangen, Germany) and gel electrophoresis. The extracts were stored at $-80^{\circ} \mathrm{C}$ until real-time PCR analysis. 


\subsubsection{Quantitative real-time PCR assay to quantify key marker genes for $\mathrm{N}$ turnover processes}

Quantitative real-time PCR (qPCR) was performed using an ABI 7300 Cycler (Life Technologies, Darmstadt, Germany) with the following assay reagents: dimethyl sulfoxide (DMSO) and bovine serum albumin (BSA) (Sigma Aldrich, Taufkirchen, Germany ), primers listed in Table 4.9 (Metabion, Martinsried, Germany) and 2x Power SYBR Green master mix (Life Technologies, Darmstadt, Germany). The respective reaction mixtures (total volume 25 $\mu \mathrm{l})$ for quantification of the genes (Table S9) consisted of: $12.5 \mu$ I SYBR Green master mix, 5 pmol of each primer (for apr gene: 10 pmol of each primer), $0.5 \mu \mathrm{l} 3 \% \mathrm{BSA}$ and $2 \mu \mathrm{I}$ DNA template. For the amplification of nirS, and nirK genes, $0.5 \mu \mathrm{LMSO}$ was added.

Table 4.9: Primer sets and thermal profiles used for the absolute quantification of the respective genes

\begin{tabular}{|c|c|c|c|c|c|}
\hline $\begin{array}{l}\text { Target } \\
\text { gene }\end{array}$ & $\begin{array}{l}\text { Source of } \\
\text { standard }\end{array}$ & Primer & References & Thermal profile & $\begin{array}{l}\text { No. of } \\
\text { cycles }\end{array}$ \\
\hline nifH & $\begin{array}{l}\text { Azospirillum } \\
\text { irakense }\end{array}$ & nifH-f, nifH-r & Rösch et al. 2002 & $\begin{array}{l}95^{\circ} \mathrm{C}-45 \mathrm{~s} / 55^{\circ} \mathrm{C}- \\
45 \mathrm{~s} / 72^{\circ} \mathrm{C}-45 \mathrm{~s}\end{array}$ & 40 \\
\hline $\mathrm{AOA}$ & $\begin{array}{l}\text { Nitrosomonas } \\
\text { europaea }\end{array}$ & $\begin{array}{l}\text { amo19F, } \\
\text { CrenamoA16r48x }\end{array}$ & $\begin{array}{l}\text { Leininger et al. 2006; } \\
\text { Schauss et al. } 2009\end{array}$ & $\begin{array}{l}94^{\circ} \mathrm{C}-45 \mathrm{~s} / 55^{\circ} \mathrm{C}- \\
45 \mathrm{~s} / 72^{\circ} \mathrm{C}-45 \mathrm{~s}\end{array}$ & 40 \\
\hline$A O B$ & $\begin{array}{l}\text { Fosmid clone } \\
54 d 9\end{array}$ & amoA1F, amoA2R & $\begin{array}{l}\text { Rotthauwe et al. } \\
1997\end{array}$ & $\begin{array}{l}94^{\circ} \mathrm{C}-45 \mathrm{~s} / 59^{\circ} \mathrm{C}- \\
45 \mathrm{~s} / 72^{\circ} \mathrm{C}-45 \mathrm{~s}\end{array}$ & 40 \\
\hline nirs & $\begin{array}{l}\text { Pseudomonas } \\
\text { stutzeri }\end{array}$ & $\mathrm{cd} 3 \mathrm{aF}, \mathrm{R} 3 \mathrm{~cd}$ & $\begin{array}{l}\text { Michotey et al. } 2000 \text {; } \\
\text { Throbäck et al. } 2004\end{array}$ & $\begin{array}{l}95^{\circ} \mathrm{C}-45 \mathrm{~s} / 57^{\circ} \mathrm{C}- \\
45 \mathrm{~s} / 72^{\circ} \mathrm{C}-45 \mathrm{~s}\end{array}$ & 40 \\
\hline \multirow[t]{2}{*}{ nirk } & $\begin{array}{l}\text { Azospirillum } \\
\text { irakense }\end{array}$ & nirk876, nirK5R & $\begin{array}{l}\text { Braker et al. } 1998 ; \\
\text { Henry et al. } 2004\end{array}$ & $\begin{array}{l}95^{\circ} \mathrm{C}-15 \mathrm{~s} / 63- \\
58^{\circ} \mathrm{C}-30 \mathrm{~s} / 72^{\circ} \mathrm{C}- \\
30 \mathrm{~s}\end{array}$ & 5 * \\
\hline & & & & $\begin{array}{l}95^{\circ} \mathrm{C}-15 \mathrm{~s} / 58^{\circ} \mathrm{C}- \\
30 \mathrm{~s} / 72^{\circ} \mathrm{C}-30 \mathrm{~s}\end{array}$ & 40 \\
\hline \multirow[t]{2}{*}{ nos $Z$} & $\begin{array}{l}\text { Pseudomonas } \\
\text { stutzeri }\end{array}$ & nosZ2F, nosZ2R & Henry et al. 2006 & $\begin{array}{l}95^{\circ} \mathrm{C}-15 \mathrm{~s} / 65- \\
60^{\circ} \mathrm{C}-30 \mathrm{~s} / 72^{\circ} \mathrm{C}- \\
30 \mathrm{~s}\end{array}$ & 5 * \\
\hline & & & & $\begin{array}{l}95^{\circ} \mathrm{C}-15 \mathrm{~s} / 60^{\circ} \mathrm{C}- \\
30 \mathrm{~s} / 72^{\circ} \mathrm{C}-30 \mathrm{~s}\end{array}$ & 40 \\
\hline chiA & $\begin{array}{l}\text { Streptomyces } \\
\text { griseus }\end{array}$ & chiF2, chiR & Xiao et al. 2005 & $\begin{array}{l}95^{\circ} \mathrm{C}-30 \mathrm{~s} / 60^{\circ} \mathrm{C}- \\
30 \mathrm{~s} / 72^{\circ} \mathrm{C}-60 \mathrm{~s}\end{array}$ & 40 \\
\hline$a p r$ & $\begin{array}{l}\text { Pseudomonas } \\
\text { aeruginosa }\end{array}$ & FPapr1, RPapr2 & Bach et al. 2001 & $\begin{array}{l}95^{\circ} \mathrm{C}-20 \mathrm{~s} / 53^{\circ} \mathrm{C}- \\
30 \mathrm{~s} / 72^{\circ} \mathrm{C}-60 \mathrm{~s}\end{array}$ & 40 \\
\hline
\end{tabular}

${ }^{*}$ Touchdown: $-1{ }^{\circ} \mathrm{C}$ per cycle

For quantification, standard curves were calculated using serial dilutions $\left(10^{1}\right.$ to $10^{6}$ gene copies $\mu^{-1}$ ) of plasmid DNA containing PCR products of the respective genes (Table S9). According to manufacturer's instruction, the PCR detection limit was assessed to 10 gene copies. In advance, the optimal dilution for each amplification assay was determined by dilution series of randomly chosen DNA extracts (data not shown), in order to prevent PCR inhibition. The qPCR assays were performed in 96-well plates (Life Technologies, Darmstadt, Germany) for all target genes (Table 4.9). All PCR runs began with a hot start at $95^{\circ} \mathrm{C}$ for 10 minutes. After each run, the specificity of the SYBR Green-quantified amplicons was checked by melting curve analysis and gel electrophoresis. The amplification efficiency was calculated from the formula $\mathrm{Eff}=\left[10^{(-1 / \mathrm{slope})}-1\right]$ and resulted in the following average efficiencies (standard deviation less than $5 \%$ of mean) for the different genes: nifH, $88 \%$, AOA, 89\%, AOB, 97\%, nirS, 90\%, nirK, 94\%, nosZ, 86\%, chiA, 90\%, apr, 90\%. 


\subsubsection{Calculation of $\mathrm{N}$ pools, isotope recovery and gross rates of $\mathrm{N}$ turnover}

Measurements of $\mathrm{N}$ pool size in soil and plant as well as isotopic information of plant, soil organic, inorganic, microbial and mycorrhizal $\mathrm{N}$ pools was used to calculate gross rates of $\mathrm{N}$ turnover and isotope tracer recovery.

\section{$\underline{\text { Calculation of dry soil weight }}$}

$s d w(g)=s f w * \frac{D}{W}$

sdw : soil dry weight (g)

$s f w$ : soil fresh weight in the mini lysimeter $(g)$

$D / W$ : quotient between dry soil after drying at $105^{\circ} \mathrm{C}$ and field fresh wet soil

\section{$\underline{\text { Total extractable soil } \mathrm{N} \text { pool sizes }}$}

Ammonium-N pool $\left({ }^{14+15} \mathrm{NH}_{4}^{+}\right)[\mu \mathrm{g} \mathrm{N} / \mathrm{g} \mathrm{sdw}]$

$\left[\mathrm{NH}_{4}^{+}\right]=\left(\left[\operatorname{concNH} H_{4}^{+}\right]-\mathrm{BV}\right) *\left(\frac{\mathrm{VK}_{2} \mathrm{SO}_{4}+s f w-s d w}{s d w}\right)$

concNH$H_{4}^{+}$: concentration of $\mathrm{NH}_{4}+$ in soil extract $\left(\mathrm{mg} \mathrm{N}^{-1}\right)$

$\mathrm{BV}=$ blind value conc $\mathrm{NH}_{4}^{+}-\mathrm{N}_{\text {in }} \mathrm{K}_{2} \mathrm{SO}_{4}$

$\mathrm{VK}_{2} \mathrm{SO}_{4}=$ volume $0.5 \mathrm{M} \mathrm{K}_{2} \mathrm{SO}_{4}(\mathrm{ml})$

Nitrate pool $\left({ }^{14+15} \mathrm{NO}_{3}^{-}\right)[\mu \mathrm{g} \mathrm{N} / \mathrm{g} \mathrm{sdw}]$

$\left[\mathrm{NO}_{3}^{-}\right]=\left(\left[\operatorname{concNO} O_{3}^{-}\right]-\mathrm{BV}\right) *\left(\frac{V K_{2} \mathrm{SO}_{4}+s f w-a s d w}{a s d w}\right)$

Dissolved organic $\mathrm{N}$ pool $\left({ }^{14+15} \mathrm{DON}\right)\left[\mathrm{mg} \mathrm{N} / \mathrm{kg} \mathrm{sdw}\right.$ ] calculated as $\mathrm{TN}_{\mathrm{b}}$-DIN

$[14+15 D O N]=\left(\left[T N_{b}-D I N\right]-B V\right) *\left(\frac{V K_{2} S_{4}+s f w-a s d w}{a s d w}\right)$

TNb: total chemically bound $N$ in soil extracts ( $\left.\mathrm{mg} \mathrm{l}^{-1}\right)$

DIN: dissolved inorganic $N$ in soil extracts ( $\left.\mathrm{mg} \mathrm{l}^{-1}\right)$

Microbial biomass nitrogen (MBN) $\left[\mathrm{mg} \mathrm{N} \mathrm{kg}^{-1} \mathrm{sdw}\right] ;(\mathrm{X})_{\text {fum }}=$ data from chloroform fumigated soil

$$
[M B N]=\left(\left[T N_{b}\right]-B V *\left(\frac{V K_{2} S O_{4}+s f w-a s d w}{a s d w}\right)\right)_{f u m}-\left(\left[T N_{b}\right]-B W *\left(\frac{V K_{2} S O_{4}+s f w-a s d w}{a s d w}\right)\right)
$$

Plant pool (P) [mg N mesocosm $\left.{ }^{-1}\right]$

$[P]=([P])_{\text {stem }}+([P])_{\text {leaves }}+([P])_{\text {roarse }}^{\text {roots }}+([P])_{\text {roots }}^{\text {fine }}$

$[P]=\frac{p d w * \% N}{100}$

pdw=total dry weight of plant tissue ( $\mathrm{mg})$

Information on soil and plant $\mathrm{N}$ pools was transferred to the unit $\mathrm{mg} \mathrm{N} \mathrm{m}^{-2}$, considering the dry mass of soil contained in a beech-soil-mesocosm and/or the surface area. 


\section{${ }^{15} \mathrm{~N}$ excess amount}

$\mathrm{NH}_{4}^{+}, \mathrm{NO}_{3}^{-}, \mathrm{DON}\left[\mathrm{mg} \mathrm{N} \mathrm{kg}^{-1} \mathrm{sdw}\right]$

$\left[{ }^{*} X\right]=[X] *\left(\frac{\left[{ }^{\%} X\right]_{t}-\left(\left[{ }^{\%} X\right]_{t}\right)_{\text {abut }}}{100}\right)$

$\left[{ }^{*} X\right]={ }^{15} \mathrm{~N}$ excess amount ( $\left.\mathrm{mg} \mathrm{N} \mathrm{kg-1} \mathrm{sdw}\right)$ with $X=\mathrm{NH}_{4}^{+}, \mathrm{NO}_{3}^{-}$or DON

[X]: N concentration in pool $X\left(\mathrm{mg} \mathrm{N} \mathrm{kg}^{-1} \mathrm{sdw}\right)$

$[\% X]$ : Atom\% ${ }^{15} \mathrm{~N}$ enrichment of pool $X$

Nat abund: natural abundance ${ }^{15} \mathrm{~N}$ atom\% excess (unlabelled soil).

${ }^{15} \mathrm{~N}$ excess amount in microbial biomass (MBN) [mg N kg$\left.{ }^{-1} \mathrm{sdw}\right]$

$\left[{ }^{*} M B N\right]=\frac{\left(\left[{ }^{\%} M B N\right] *\left[T N_{b}\right]\right)_{f u m}-\left[{ }^{\%} M B N\right] *\left[T N_{b}\right]}{\left(\left[T N_{b}\right]\right)_{f u m}-\left[T N_{b}\right]}$

${ }^{15} \mathrm{~N}$ excess amount in plant biomass [mg N lysimeter ${ }^{-1}$ ]

$\left[{ }^{*} P\right]_{t}=$

$\left(\left([P]_{t}\right)_{\text {stem }} *\left(\left[{ }^{\%} P\right]_{t}-\left(\left[{ }^{\%} P\right]_{t}\right)_{\text {abund }}^{\text {nat }}\right)_{\text {stem }}\right)+\left(\left([P]_{t}\right)_{\text {leaves }} *\left(\left[{ }^{\%} P\right]_{t}-\left(\left[{ }^{\%} P\right]_{t}\right)_{\text {abund }}\right)_{\text {leaves }}\right)+$

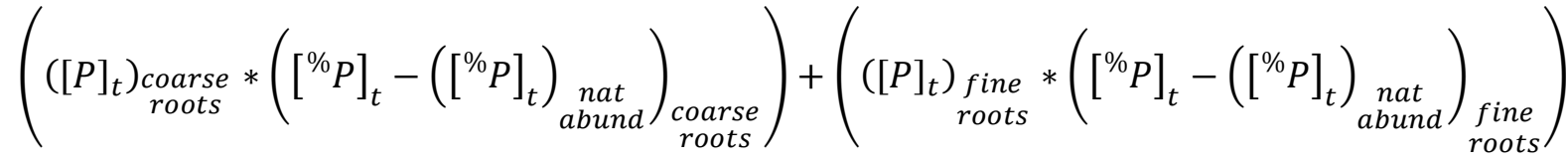

The recovery of ${ }^{15} \mathrm{~N}$ excess added by labelling was calculated by dividing the ${ }^{15} \mathrm{~N}$ excess amount detected in the investigated pools by the original amount of ${ }^{15} \mathrm{~N}$ excess added through the labelling solution.

\section{Calculation of gross rates of nitrogen turnover}

Gross rates of ammonification and nitrification were calculated following the ${ }^{15} \mathrm{~N}$ pool dilution equations given by Kirkham and Bartholomew (Kirkham and Bartholomew 1954).

Ammonification [mg N kg-1 sdw day 1$]=\frac{\left[\mathrm{NH}_{4}^{+}\right]_{6}-\left[\mathrm{NH}_{4}^{+}\right]_{48}}{1.75 \text { days }} * \ln \left(\frac{\left[{ }^{*} \mathrm{NH}_{4}^{+}\right]_{6}{ }^{*}\left[\mathrm{NH}_{4}^{+}\right]_{48}}{\left.\left[{ }^{*} \mathrm{NH}_{4}^{+}\right]_{48}{ }_{48} \mathrm{NH}_{4}^{+}\right]_{6}}\right) \% \ln \frac{\left[\mathrm{NH}_{4}^{+}\right]_{6}}{\left[\mathrm{NH}_{4}^{+}\right]_{48}}$

Subscript []: Measurement time ( $0=$ before labelling; $6=6$ hours after ${ }^{15} \mathrm{~N}$ application; $48=48$ hours after ${ }^{15} \mathrm{~N}$ application)

Nitrification [mg N kg-1 sdW day-1] $=\frac{\left[\mathrm{NO}_{3}^{-}\right]_{6}-\left[\mathrm{NO}_{3}^{-}\right]_{48}}{1.75 \text { days }} * \ln \left(\frac{\left[{ }^{*} \mathrm{NO}_{3}^{-}\right]_{6} *\left[\mathrm{NO}_{3}^{-}\right]_{48}}{\left[{ }^{*} \mathrm{NO}_{3}^{-}\right]_{48} *\left[\mathrm{NO}_{3}^{-}\right]_{6}}\right) \% \ln \frac{\left[\mathrm{NO}_{3}^{-}\right]_{6}}{\left[\mathrm{NO}_{3}^{-}\right]_{48}}$

Plant $\mathrm{N}$ uptake and microbial immobilization of inorganic $\mathrm{N}$ was calculated based on shortterm tracing (6 hours) of labelled substances $\left({ }^{15} \mathrm{NH}_{4}{ }^{+},{ }^{15} \mathrm{NO}_{3}{ }^{-}\right)$into plant biomass (Stark 2000). The short period was chosen to minimize bias due to unquantified tracer outflow from the sink pools and depletion of tracer in the source pool (Näsholm et al. 2009, Stark 2000). 
Plant $\mathrm{NH}_{4}^{+}$uptake $\left[\mathrm{mg}\right.$ N lysimeter ${ }^{-1}$ day $\left.^{1}\right]=\frac{\left[{ }^{*} \mathrm{P}\right]_{6}}{\text { Average }\left(\left[{ }^{\left[P E_{N} H_{4}^{+}\right.}\right]_{0} ;\left[{ }^{A P E_{N}}{ }_{4}^{+}\right]_{6}\right) * 0.25 \text { days }}$

[APE]: Atom\% excess of pool X

$\left[{ }^{A P E} \mathrm{NH}_{4}^{+}\right]_{0}={ }^{15} \mathrm{NH}_{4}^{+}-\mathrm{N}$ atomic \% excess immediately after ${ }^{15} \mathrm{~N}$ labelling

$\left[{ }^{A P E} \mathrm{NH}_{4}^{+}\right]_{6}={ }^{15} \mathrm{NH}_{4}^{+}-\mathrm{N}$ atomic \% excess six hours after labelling.

Plant $\mathrm{NO}_{3}^{-}$uptake $\left[\right.$mg N lysimeter $\left.{ }^{-1}\right]=\frac{\left[{ }^{*}\right]_{6}}{\text { Average }\left(\left[{ }^{A P E_{N O}}{ }_{3}^{-}\right]_{0} ;\left[{ }^{A P E_{N}} \mathrm{NO}_{3}^{-}\right]_{6}\right) * 0.25 \text { days }}$

Microbial $\mathrm{NH}_{4}^{+}$inmobilization $\left[\mathrm{mg} N \mathrm{~kg}^{-1} \mathrm{sdw}\right.$ day $\left.{ }^{-1}\right]=\frac{[\mathrm{MB}]_{6} *\left[{ }^{*} \mathrm{MB}\right]_{6}}{\text { Average }\left(\left[{ }^{A P E_{N}} \mathrm{H}_{4}^{+}\right]_{0^{;}}\left[{ }^{A P E}{ }^{+} H_{4}^{+}\right]_{6}\right) * 0.25 \text { days }}$

Microbial $\mathrm{NO}_{3}^{-}$immobilization $\left[\mathrm{mg} \mathrm{N} \mathrm{kg}^{-1} \mathrm{sdw}\right.$ day $\left.{ }^{-1}\right]=\frac{[\mathrm{MB}]_{6} *\left[{ }^{*} \mathrm{MB}\right]_{6}}{\left.\operatorname{Average}\left(\left[{ }^{A P E_{N O}}\right]_{3}\right]_{0}\left[{ }^{A P E_{N O}}\right]_{6}\right) * 0.25 \text { days }}$

All $\mathrm{N}$ turnover rates were transferred to the unit $\mathrm{mg} \mathrm{N} \mathrm{m}^{-2}$ day $^{-1}$, considering total dry soil contained in the beech-soil-mesocosm and the surface area. Plant uptake rates were transferred to the same unit by considering the surface area of the beech-soil-mesocosm.

\subsubsection{Statistics}

Experimental data is generally shown as mean values with standard errors (SE) of the mean, if not otherwise stated. Data were log-transformed if necessary to meet the requirement of normality and subsequently analyzed using two-way ANOVA with the factors exposure (NW versus SW exposure, i. e. control and climate change treatments), time and their interaction. Depending on the parameters investigated, the factor time has different levels with independent observations, since samples were taken from different beech-seedling-soil mesocosms. There were two levels for gross rates of $\mathrm{N}$ turnover (June, September), three levels for $\mathrm{N}$ pools and microbial $\mathrm{N}$ cycle gene abundance (June, August, September) and five levels for isotopic composition of $\mathrm{C}$ and $\mathrm{N}$ pools (June_6 hours after labelling; June_48 hours after isotope labelling; August_6hours after isotope labelling; August_48 hours after isotope labelling and September_3months after isotope labelling). Differences between the levels of the time factor within each treatment level were further tested by applying the Tukey post-hoc test. For plant metabolites in fine roots, single comparisons between SW and NW were performed with non-parametric u-tests due to smaller number of replicates. 


\subsection{References}

Asch K. 2003. The 1:5 million international geological map of Europe and adjacent areas. German federal agency for geosciences and raw materials, Hannover.

Bach H.-J., Hartmann A., Schloter M., Munch J.C. 2001. PCR primers and functional probes for amplification and detection of bacterial genes for extracellular peptidases in single strains and in soil. J. Microbiol. Methods. 44:173-182.

BGR 2003. Geological map of Germany, Scale 1:1000000, 4th edition. German federal agency for geosciences and raw materials, Hannover.

Bimüller C., Dannenmann M., Tejedor J., von Lützow M., Buegger F., Meier R., Haug S., Schroll R., Kögel-Knabner I. 2014. Prolonged summer droughts retard soil N processing and stabilization in organo-mineral fractions. Soil Biol. Biochem. 68:241-251.

Braker G., Fesefeldt A., Witzel K.-P. 1998. Development of PCR primer systems for amplification of nitrite reductase genes (nirK and nirS) to detect denitrifying bacteria in environmental samples. Appl. Environ. Microbiol. 64:3769-3775.

Cohen J. 1960. A coefficient of agreement for nominal scales. Educ. Psychol. Meas. 20:3746.

Coumou D., Robinson A., Rahmstorf S. 2013. Global increase in record-breaking monthlymean temperatures. Clim. Change. 118:771-782.

Dannenmann M., Butterbach-Bahl K., Gasche R., Willibald G., Papen H. 2008. Dinitrogen emissions and the $\mathrm{N}_{2}: \mathrm{N}_{2} \mathrm{O}$ emission ratio of a Rendzic Leptosol as influenced by $\mathrm{pH}$ and forest thinning. Soil Biol. Biochem. 40:2317-2323.

Dannenmann M., Gasche R., Ledebuhr A., Papen H. 2006. Effects of forest management on soil $\mathrm{N}$ cycling in beech forests stocking on calcareous soils. Plant Soil. 287:279-300.

Dannenmann M., Simon J., Gasche R., Holst J., Naumann P.S., Kögel-Knabner I., Knicker H., Mayer H., Schloter M., Pena R., Polle A., Rennenberg H., Papen H. 2009. Tree girdling provides insight on the role of labile carbon in nitrogen partitioning between soil microorganisms and adult European beech. Soil Biol. Biochem. 41:1622-1631.

Ellenberg H., Leuschner C. 1996. Vegetation Mitteleuropas mit den Alpen in ökologischer, dynamischer und historischer Sicht. Ulmer, Stuttgart.

Fischer R., Lorenz M., Köhl M., Mues V., Granke O., lost S., van Dobben H., Reinds G.J., de Vries W. 2010. The condition of forests in Europe. 2010 Executive Report. ICP For. Eur. Comm. Hambg. Bruss. Ger. Belg.

Geßler A., Jung K., Gasche R., Papen H., Heidenfelder A., Börner E., Metzler B., Augustin S., Hildebrand E., Rennenberg H. 2005. Climate and forest management influence nitrogen 
balance of European beech forests: microbial $\mathrm{N}$ transformations and inorganic $\mathrm{N}$ net uptake capacity of mycorrhizal roots. Eur. J. For. Res. 124:95-111.

Geßler A., Keitel C., Kreuzwieser J., Matyssek R., Seiler W., Rennenberg H. 2007. Potential risks for European beech (Fagus sylvatica L.) in a changing climate. Trees. 21:1-11.

Geßler A., Keitel C., Nahm M., Rennenberg H. 2004. Water shortage affects the water and nitrogen balance in Central European beech forests. Plant Biol. Stuttg. Ger. 6:289-298.

Gordon C., Cooper C., Senior C.A., Banks H., Gregory J.M., Johns T.C., Mitchell J.F.B., Wood R.A. 2000. The simulation of SST, sea ice extents and ocean heat transports in a version of the Hadley Centre coupled model without flux adjustments. Clim. Dyn. 16:147168.

Guo C., Simon J., Gasche R., Naumann P.S., Bimüller C., Pena R., Polle A., Kögel-Knabner I., Zeller B., Rennenberg H., Dannenmann M. 2013. Minor contribution of leaf litter to N nutrition of beech (Fagus sylvatica) seedlings in a mountainous beech forest of Southern Germany. Plant Soil. 369:657-668.

Haas E., Klatt S., Fröhlich A., Kraft P., Werner C., Kiese R., Grote R., Breuer L., ButterbachBahl K. 2013. LandscapeDNDC: a process model for simulation of biosphere-atmospherehydrosphere exchange processes at site and regional scale. Landsc. Ecol. 28:615-636.

Hanewinkel M., Cullmann D.A., Schelhaas M.-J., Nabuurs G.-J., Zimmermann N.E. 2013. Climate change may cause severe loss in the economic value of European forest land. Nat. Clim. Change. 3:203-207.

Hanewinkel M., Cullmann D.A., Michiels H.G. 2013b. Converting probabilistic tree species range shift projections into meaningful classes for management. J. Env. Manage. (in review, "minor revisions").

Henry S., Baudoin E., López-Gutiérrez J.C., Martin-Laurent F., Brauman A., Philippot L. 2004. Quantification of denitrifying bacteria in soils by nirK gene targeted real-time PCR. J. Microbiol. Methods. 59:327-335.

Henry S., Bru D., Stres B., Hallet S., Philippot L. 2006. Quantitative detection of the nosZ gene, encoding nitrous oxide reductase, and comparison of the abundances of 16S rRNA, narG, nirK, and nosZ genes in soils. Appl. Environ. Microbiol. 72:5181-5189.

Hijmans R.J., Cameron S.E., Parra J.L., Jones P.G., Jarvis A. 2005. Very high resolution interpolated climate surfaces for global land areas. Int. J. Climatol. 25:1965-1978.

Kirkham D., Bartholomew W.V. 1954. Equations for following nutrient transformations in soil, utilizing tracer data 1. Soil Sci. Soc. Am. J. 18:33.

Kohler M., Sohn J., Nägele G., Bauhus J. 2010. Can drought tolerance of Norway spruce (Picea abies (L.) Karst.) be increased through thinning? Eur. J. For. Res. 129:1109-1118. 
Kreuzwieser J., Gessler A. 2010. Global climate change and tree nutrition: influence of water availability. Tree Physiol. 30:1221-1234.

Leininger S., Urich T., Schloter M., Schwark L., Qi J., Nicol G.W., Prosser J.I., Schuster S.C., Schleper C. 2006. Archaea predominate among ammonia-oxidizing prokaryotes in soils. Nature. 442:806-809.

Leuschner C., Backes K., Hertel D., Schipka F., Schmitt U., Terborg O., Runge M. 2001. Drought responses at leaf, stem and fine root levels of competitive Fagus sylvatica L. and Quercus petraea (Matt.) Liebl. trees in dry and wet years. For. Ecol. Manag. 149:33-46.

Mayer H., Holst T., Schindler D. 2002. Microclimate within beech stands - Part I: Photosynthetically active radiation. Forstwiss. Cent. 121:301-321.

Meier I.C., Leuschner C. 2010. Variation of soil and biomass carbon pools in beech forests across a precipitation gradient. Glob. Change Biol. 16:1035-1045.

Michotey V., Méjean V., Bonin P. 2000. Comparison of methods for quantification of cytochrome cd 1-denitrifying bacteria in environmental marine samples. Appl. Environ. Microbiol. 66:1564-1571.

Moosmayer H.-U. 2002. Langfristige regionale Waldbauplanung in Baden-Württemberg: Grundlagen und Ergebnisse. Selbstverl. der Landesforstverwaltung Baden-Württemberg.

Intergovernmental Panel on Climate Change, Working Group III. 2000. Emissions scenarios: a special report of IPCC Working Group III. ISBN 92-9169-113-5.

Näsholm T., Kielland K., Ganeteg U. 2009. Uptake of organic nitrogen by plants. New Phytol. 182:31-48.

O’Neill G.A., Nigh G., Wang T., Ott P.K. 2007. Growth response functions improved by accounting for nonclimatic site effects. Can. J. For. Res. 37:2724-2730.

Norton J.M., Stark J.M. 2011. Regulation and measurement of nitrification in terrestrial systems. In: Klotz M.G. (ed.): Methods in Enzymology: Research on nitrification and related processes 486, 343-368. Elsevier Academic Press, Burlington.

Pena R., Offermann C., Simon J., Naumann P.S., Geßler A., Holst J., Dannenmann M., Mayer H., Kogel-Knabner I., Rennenberg H., Polle A. 2010. Girdling affects ectomycorrhizal fungal (EMF) diversity and reveals functional differences in EMF community composition in a beech forest. Appl. Environ. Microbiol. 76:1831-1841.

Pretzsch H., Schütze G., Uhl E. 2013. Resistance of European tree species to drought stress in mixed versus pure forests: evidence of stress release by inter-specific facilitation. Plant Biol. Stuttg. Ger. 15:483-495. 
Rennenberg H., Dannenmann M., Geßler A., Kreuzwieser J., Simon J., Papen H. 2009. Nitrogen balance in forest soils: nutritional limitation of plants under climate change stresses. Plant Biol. 11:4-23.

Rennenberg H., Loreto F., Polle A., Brilli F., Fares S., Beniwal R.S., Gessler A. 2006. Physiological responses of forest trees to heat and drought. Plant Biol. 8:556-571.

Rösch C., Mergel A., Bothe H. 2002. Biodiversity of denitrifying and dinitrogen-fixing bacteria in an acid forest soil. Appl. Environ. Microbiol. 68:3818-3829.

Rotthauwe J.H., Witzel K.P., Liesack W. 1997. The ammonia monooxygenase structural gene amoA as a functional marker: molecular fine-scale analysis of natural ammoniaoxidizing populations. Appl. Environ. Microbiol. 63:4704-4712.

Schauss K., Focks A., Leininger S., Kotzerke A., Heuer H., Thiele-Bruhn S., Sharma S., Wilke B.-M., Matthies M., Smalla K., Munch J.C., Amelung W., Kaupenjohann M., Schloter M., Schleper C. 2009. Dynamics and functional relevance of ammonia-oxidizing archaea in two agricultural soils. Environ. Microbiol. 11:446-456.

Schwarz G. 1978. Estimating the dimension of a model. Ann. Stat. 6:461-464.

Seneviratne S.I., Lüthi D., Litschi M., Schär C. 2006. Land-atmosphere coupling and climate change in Europe. Nature. 443:205-209.

Simon J., Dannenmann M., Gasche R., Holst J., Mayer H., Papen H., Rennenberg H. 2011 Competition for nitrogen between adult European beech and its offspring is reduced by avoidance strategy. For. Ecol. Manag. 262:105-114.

Simon J., Waldhecker P., Brüggemann N., Rennenberg H. 2010. Competition for nitrogen sources between European beech (Fagus sylvatica) and sycamore maple (Acer pseudoplatanus) seedlings. Plant Biol. 12:453-458.

Smiatek G., Kunstmann H., Knoche R., Marx A. 2009. Precipitation and temperature statistics in high-resolution regional climate models: Evaluation for the European Alps. J. Geophys. Res. Atmospheres. 114:n/a-n/a.

Stark J.M. 2000. Nutrient transformations. In: Sala O.E, Jackson R.B., Mooney H.A., Howarth R. (eds.), Methods in ecosystem science 215-234. Springer, New York.

Stoelken G., Simon J., Ehlting B., Rennenberg H. 2010. The presence of amino acids affects inorganic $\mathrm{N}$ uptake in non-mycorrhizal seedlings of European beech (Fagus sylvatica). Tree Physiol. 30:1118-1128.

Tarp P., Helles F., Holten-Andersen P., Bo Larsen J., Strange N. 2000. Modelling nearnatural silvicultural regimes for beech-an economic sensitivity analysis. For. Ecol. Manag. 130:187-198. 
Throbäck I.N., Enwall K., Jarvis Å., Hallin S. 2004. Reassessing PCR primers targeting nirS, nirK and nosZ genes for community surveys of denitrifying bacteria with DGGE. FEMS Microbiol. Ecol. 49:401-417.

Weber P., Bugmann H., Pluess A.R., Walthert L., Rigling A. 2013. Drought response and changing mean sensitivity of European beech close to the dry distribution limit. Trees. 27:171-181.

Winter H., Lohaus G., Heldt H.W. 1992. Phloem transport of amino acids in relation to their cytosolic levels in barley leaves. Plant Physiol. 99:996-1004.

Wu H., Dannenmann M., Fanselow N., Wolf B., Yao Z., Wu X., Brüggemann N., Zheng X., Han X., Dittert K., Butterbach-Bahl K. 2011. Feedback of grazing on gross rates of N mineralization and inorganic $\mathrm{N}$ partitioning in steppe soils of Inner Mongolia. Plant Soil. 340:127-139.

Xiao X., Yin X., Lin J., Sun L., You Z., Wang P., Wang F. 2005. Chitinase genes in lake sediments of Ardley Island, Antarctica. Appl. Environ. Microbiol. 71:7904-7909. 


\section{Synopsis}

In dieser Arbeit wurde gezeigt, dass die Zukunft der Buchennaturverjüngung und damit die Zukunft der Buchenwälder maßgeblich von der Versorgungssituation mit Stickstoff abhängt. Die sinkende Bodenfeuchte und die steigenden Temperaturen, die für die Zukunft prognostiziert werden, können sich über die Beeinträchtigung der Ektomykorrhiza- und Bakteriengesellschaften auf den Stickstoffkreislauf in Buchenwäldern auswirken. Von den Änderungen sind aufgrund der schlechten Wasser- und Stickstoffversorgung vorrangig die flachgründigen Kalkstandorte (Dannenmann et al. 2006, 2009) betroffen, die ca. ein Drittel aller Buchenwälder in Mitteleuropa ausmachen (Dannenmann et. al. unveröffentlicht). Unter Bedingungen, wie sie auf solchen Standorten vorherrschen, reagiert die Buche besonders sensitiv auf Trockenstress (Rennenberg et al. 2009). Diese Arbeit untersucht die Prozesse zwischen Buchen, Ektomykorrhizen und Bodenbakterien, die auf den genannten Standorten zu Wachstumseinschränkungen führen. Sowohl Ektomykorrhizen als auch Bodenbakterien spielen dabei eine entscheidende Rolle und konkurrieren um den verfügbaren Stickstoff. Die Rolle der Ektomykorrhizen wurde in dieser Arbeit, ausgehend von der Morphologie und Anatomie einer einzelnen Ektomykorrhizaart, sowohl in einem kontrollierten System unter Ausschluss der Konkurrenz durch Bodenbakterien und ohne umweltbedingte Einschränkungen als auch unter Freilandbedingungen in Stress- und Konkurrenzsituationen untersucht.

\subsection{Morphologie und Anatomie als Basis für die Analysen von Ektomykorrhizagesellschaften und deren Funktionen}

Funktionelle Eigenschaften der Ektomykorrhizapilze sind entscheidend, wie sich die einzelnen Pilze im Ökosystem, auch in Hinblick auf die Stickstoffversorgung ihrer Wirtspflanzen, verhalten. So hängt z.B. der Zugriff der Pilze auf unterschiedliche Stickstoffquellen maßgeblich von der Ausprägung des extramatrikalen Myzels und damit vom Explorationstyp ab (Pena et al. 2013). Informationen über solche funktionellen Merkmale können aber in vielen Fällen nicht ermittelt werden, da ein Großteil der Ektomykorrhizen, die mittels ITS-Sequenzierung bestimmt werden können, noch nicht wissenschaftlich beschrieben wurden. Damit fehlt die Verknüpfung von ITS-Sequenzen und Strukturen. Der Einsatz von Next Generation Sequencing, bei dem sehr große Mengen an Sequenzen erzeugt werden, verstärkt das Missverhältnis zwischen vorhandenen Sequenzen und vorhandenem morphologischen und anatomischen Wissen auf drastische Weise.

Die Grundlage vieler funktioneller Analysen von Ektomykorrhizapilzen ist, noch vor der ITSSequenzierung der Pilze, das Morphotyping, also das Zuordnen von mykorrhizierten Wurzelspitzen zu Morphotypen, die anhand morphologischer Merkmale unterscheidbar sind. Um dieses Verfahren wiederholbar anwenden zu können, sind Kenntnisse über die Morphologie der einzelnen Mykorrhizapilze zwingend notwendig und sollten durch Informationen zur Anatomie ergänzt werden (Anatomotyping). Werden nicht alle Möglichkeiten zur Bestimmung der Pilze ausgenutzt, ist die Gefahr von Fehlbestimmungen sehr hoch. Auf morphologischer Ebene stehen nur 7 Merkmale (Agerer 1987-2006) zur Verfügung, von denen ein sehr wesentliches, nämlich die Farbe, stark von der Lichtquelle, 
dem Alter und dem Lagerungszustand der Mykorrhiza abhängt. Werden anatomische Merkmale wie z.B. Mantelaufbau, Hyphenanatomie und Cystidenformen zusätzlich herangezogen, erhöht sich die Zahl der Merkmale um ein Vielfaches und die Bestimmungen werden sicherer. Nach der anschließende Sequenzierung der DNA der Morphotypen und dem Abgleich mit Datenbanken wie NCBI oder UNITE wird der beste Treffer für die Benennung des betreffenden Morphotyps verwendet, wenn Qualitätskriterien wie z.B. die weitverbreiteten 97 \% Identität (Brock et al. 2008) erfüllt werden. Laut Nilsson et al. (2005, 2006) sind allerding bis zu $20 \%$ der Artnamen in den Datenbanken (GenBank, EMBL, DDBJ) inkorrekt. So kann es zu Fehlbestimmungen kommen. Diese Fehlbestimmungen können erheblich vermindert werden, wenn die durch ITS-Sequenzierung bestimmten Pilze unter morphologischen und anatomischen Gesichtspunkten überprüft werden.

Wissenschaftliche Beschreibungen von Ektomykorrhizen geben Hinweise auf die Funktion der Pilze und helfen bei der Erfassung grundlegender Daten zu den Mykorrhizagesellschaften sowie bei der Überprüfung von Sequenzierungsergebnissen. Damit diese Vorteile genutzt werden können, ist eine weitgehende Erfassung und Beschreibung der vorkommenden Morphotypen notwendig. In diesen Bereich liegt allerdings ein sehr großes Defizit vor. Gerade in Hinblick auf die Anwendung des Next-GenerationSequencings ist es wichtig, den Sequenzen Strukturen oder sogar Artnamen zuordnen zu können (Glenn 2011; Shokralla et al. 2012; Bates et al. 2013). Am Ausbau der morphologischen und anatomischen Datenbanken und die Verknüpfung mit den Gendatenbanken sollte deshalb dringend gearbeitet werden. Dazu wurde hier mit der Beschreibung einer Mykorrhiza ein Beitrag geleistet.

\subsection{Ektomykorrhizapilze in der Stickstoffversorgungskette von Buchen}

Um den Einfluss der Mykorrhizapilze auf den Stickstoffkreislauf näher zu beleuchten, fanden zwei Versuche statt. Im ersten Versuch wurden genetisch ähnliche Buchen von einem NOund einem SW-Hang mit spezifischen Mykorrhizagesellschaften in homogenem Boden unter guter Wasser- und N-Versorgung kultiviert. Unter diesen Bedingungen war die Anzahl an nicht mykorrhizierten Spitzen besonders hoch, so dass ein Teil des Stickstoffs über diese Wurzelspitzen aufgenommen wurde. Der zweite Versuch fand unter Freilandbedingungen auf einem NW- und einem SW-Hang unter Verwendung von weitgehend ungestörten Mesokosmen statt. Auf beiden Hängen stammten die Buchen vom NW Hang. Im Vergleich zu dem kontrollierten System war vor allem die mikrobielle Biomasse um eine Größenordnung erhöht, was zu einer starken Konkurrenz um den Stickstoff zwischen Mikroben und Mykorrhizen führte. Da die Wurzelspitzen nahezu vollständig mykorrhiziert waren, konnte der Stickstoff nur über die Ektomykorrhizen aufgenommen werden. Auf dem SW-Hang herrschten im Vergleich zum NW-Hang eine reduzierte Bodenfeuchte und eine erhöhte Temperatur. Die Bedingungen auf dem SW-Hang entsprachen in etwa den Bedingungen des prognostizierten Klimawandels.

Es stellte sich heraus, dass unter den kontrollierten Bedingungen durch die geringe mikrobielle Biomasse im Substrat die Konkurrenz um den Stickstoff zwischen Ektomykorrhizapilzen und Bakterien erheblich vermindert wurde. Die Ektomykorrhizapilze kontrollierten unter diesen Bedingungen den Stickstofftransport in die Pflanze und waren 
somit entscheidend für die Stickstoffversorgung der Pflanze. Die beiden unterschiedlichen Mykorrhiza-Gesellschaften sorgten für eine unterschiedliche N-Versorgung der Buchen. Ein wesentlicher Unterschied zwischen den beiden Mykorrhizagesellschaften war das Verhältnis von Basidiomyceten zu Ascomyceten. Während an den NO-Buchen die Basidiomyceten dominierten, war an den SW-Buchen eine deutliche Steigerung des Ascomycetenanteils zu beobachten. Dies deckt sich mit der Beobachtung, dass in trockenen Ökosystemen Ascomyceten abundanter sind als in feuchteren Ökosystemen. Unter nicht limitierenden Umweltbedingungen ist die Mykorrhizagesellschaft der SW-Buchen also in der Lage, mehr $\mathrm{N}$ zu akkumulieren als die Mykorrhizagesellschaften der NO-Buchen. Es gab keine Hinweise, dass es physiologische Differenzen aufgrund von genetischer Anpassung oder langfristiger Anpassung gab, die die Unterschiede in der N Aufnahme verursacht haben.

Unter Freilandbedingungen akkumulierten die Mykorrhizen auf der NW-Seite unabhängig von der Stickstoffquelle mehr $\mathrm{N}$ als die Mykorrhizen auf der SW-Seite. Wegen der Inkubationszeit von einem Jahr unter den klimatischen Bedingungen auf der SW-Seite ist davon auszugehen, dass eine Anpassung der Mykorrhizapilze stattfand (Shi et al. 2002). Diese Anpassung war allerdings in Hinblick auf die Stickstoffakkumulation in den Mykorrhizen und die Stickstoffversorgung des Wirtes nicht wirksam. Sie wurde vermutlich durch die hohe Konkurrenzkraft und die geringe N Bereitstellung der Bakterien überdeckt. Unter Freilandbedingungen kontrollieren die Bakterien die Bereitstellung von anorganischem $\mathrm{N}$ und damit die Stickstoffversorgung der Buche. Unter den klimatischen Bedingungen auf dem SW Hang nimmt die Abundanz der nitrifizierenden Bakterien ab, was zu einem massiver Einbruch von der Bruttonitratproduktion und der Nitratverfügbarkeit führt. Die reduzierte N-Aufnahme der Buchen und Mykorrhizapilze auf dem SW Hang im Vergleich zum NW Hang spiegelte sich in der reduzierten Biomasse der Buchennaturverjüngung auf dem SW Hang wieder. Der gleiche Effekt ist auch anhand der Biomasse der adulten Buchen zu erkennen (Geßler et al. 2005).

Im Freiland war Nitrat die dominante N-Quelle für die Buchennaturverjüngung, gefolgt von Ammonium und Glutamin. Die mykorrhizierten Spitzen nahmen dagegen Ammonium bevorzugt auf. Dies stimmt mit zuvor durchgeführten Aufnahmeexperimenten überein (Geßler et al. 1998, 2005). Das Ammonium wird also von den mykorrhizierten Spitzen stark aufgenommen, verbleibt aber überwiegend dort und wird im Vergleich zu Nitrat in geringerem Umfang an die nachfolgenden Pflanzenteile weitergegeben. Auch unter den kontrollierten Bedingungen wurde von den Mykorrhizen viel Ammonium aufgenommen, aber im Vergleich zu Nitrat unter Freilandbedingungen ebenfalls nur in geringem Maße an die Pflanze weitergegeben. In früheren Publikation (Dannenmann et al. 2009; Näsholm et al. 2009; Simon et al. 2010, 2011; Stoelken et al. 2010) wurde vermutet, dass organische Stickstoffquellen eine bedeutende Rolle für die Stickstoffversorgung der Pflanzen spielen könnten. Im Experiment unter Freilandbedingungen bestätigte sich dies für die Buchennaturverjüngung aber nicht, da insbesondere nach 6 und $48 \mathrm{~h}$ Einwirkzeit des Labels im Vergleich zu den anorganischen Stickstoffformen nur sehr geringe Mengen an ${ }^{15} \mathrm{~N}$ und ${ }^{13} \mathrm{C}$ aus dem Glutamin in den Mykorrhizen und den Buchen wiedergefunden wurden. Vermutlich liegt das an der Anwesenheit von konkurrenzstarken Bakterien, die in den Aufnahmeexperimenten von Simon et al. (2011), die an freigelegten Wurzeln in einer Nährlösung durchgeführt wurden und hohe Aufnahmeraten von Glutamin ergaben, keine Rolle spielten. Dies zeigt, dass nicht ohne weiteres von Ergebnissen aus solchen 
Aufnahmeexperimenten auf die Zustände unter Freilandbedingungen, bzw. auf die Wirksamkeit für die Pflanzenernährung geschlossen werden kann.

Die Ergebnisse der beiden Experimente legen nahe, dass es für den Erhalt von produktiven Buchenwäldern nicht ausreicht, nach trockenheitstoleranten Buchen-Herkünften zu suchen. Vielmehr müsste mindestens im gleichen Umfang nach Ektomykorrhizen und Bakterien gesucht werden, die im Falle der Ektomykorrhizen unter zukünftigen Klimabedingungen konkurrenzstark Stickstoff akquirieren und diesen an die Pflanzen weitergeben und im Falle der Bakterien Nitrat in ausreichenden Mengen unter den künftigen Klimabedingungen bereitstellen können, um die Stickstoffversorgung der Buchen zu gewährleisten. Diese Arbeit liefert grundlegenden Vorstellungen zu den Prozessen der N-Versorgung von Buchen auf Nlimitierten Böden im Zusammenspiel mit Ektomykorrhizen und Bodenbakterien unter Klimawandelbedingungen. Damit eröffnen sich neue Ansätze, den negativen Folgen des prognostizierten Klimawandel für die Buchenwälder zu begegnen. 


\subsection{Literatur}

Agerer R. 1987-2006. Colour Atlas of Ectomycorrhizae. Einhorn Verlag, Schwäbisch-Gmünd.

Bates S.T., Ahrendt S., Bik H.M., Bruns T.D., Caporaso J.G., Cole J., Dwan M., Fierer N., Gu D., Houston S., Knight R., Leff J., Lewis C., Maestre J.P., McDonald D., Nilsson R.H., Porras-Alfaro A., Robert V., Schoch C., Scott J., Taylor D.L., Parfrey L.W., Stajich J.E. 2013. Meeting report: fungal ITS workshop (October 2012). Stand. Genomic Sci. 8.

Bilela S., Dounavi A., Fussi B., Konnert M., Holst J., Mayer H., Rennenberg H., Simon J. 2012. Natural regeneration of Fagus sylvatica L. adapts with maturation to warmer and drier microclimatic conditions. For. Ecol. Manag. 275:60-67.

Brock P.M., Döring H., Bidartondo M.I. 2009. How to know unknown fungi: the role of a herbarium. New Phytol. 181:719-724.

Dannenmann M., Gasche R., Ledebuhr A., Papen H. 2006. Effects of forest management on soil N cycling in beech forests stocking on calcareous soils. Plant Soil. 287:279-300.

Dannenmann M., Simon J., Gasche R., Holst J., Naumann P.S., Kögel-Knabner I., Knicker H., Mayer H., Schloter M., Pena R., Polle A., Rennenberg H., Papen H. 2009. Tree girdling provides insight on the role of labile carbon in nitrogen partitioning between soil microorganisms and adult European beech. Soil Biol. Biochem. 41:1622-1631.

Dannenmann M., Bimüller C., Gschwendtner S., Leberecht M., Tejedor J., Bilela S., Gasche R., Hanewinkel M., Baltensweiler A., Kögel-Knabner I., Polle A., Schloter M, Simon J., Rennenberg $\mathrm{H}$. unveröffentlicht. Climate change impairs nitrogen cycling in European beech forests. Eingereicht am 09.11.2013 bei Nature Geoscience.

Geßler A., Jung K., Gasche R., Papen H., Heidenfelder A., Börner E., Metzler B., Augustin S., Hildebrand E., Rennenberg H. 2005. Climate and forest management influence nitrogen balance of European beech forests: microbial $\mathrm{N}$ transformations and inorganic $\mathrm{N}$ net uptake capacity of mycorrhizal roots. Eur. J. For. Res. 124:95-111.

Geßler A., Schneider S., Von Sengbusch D., Weber P., Hanemann U., Huber C., Rothe A., Kreutzer K., Rennenberg H. 1998. Field and laboratory experiments on net uptake of nitrate and ammonium by the roots of spruce (Picea abies) and beech (Fagus sylvatica) trees. New Phytol. 138:275-285.

Glenn T.C. 2011. Field guide to next-generation DNA sequencers. Mol. Ecol. Resour. 11:759-769.

Näsholm T., Kielland K., Ganeteg U. 2009. Uptake of organic nitrogen by plants. New Phytol. 182:31-48. 
Nilsson R.H., Kristiansson E., Ryberg M., Larsson K.-H. 2005. Approaching the taxonomic affiliation of unidentified sequences in public databases - an example from the mycorrhizal fungi. BMC Bioinformatics. 6:178.

Nilsson R.H., Ryberg M., Kristiansson E., Abarenkov K., Larsson K.-H., Kõljalg U. 2006. Taxonomic reliability of DNA sequences in public sequence databases: a fungal perspective. PLoS ONE. 1:e59.

Pena R., Tejedor J., Zeller B., Dannenmann M., Polle A. 2013. Interspecific temporal and spatial differences in the acquisition of litter-derived nitrogen by ectomycorrhizal fungal assemblages. New Phytol. 199:520-528.

Rennenberg H., Dannenmann M., Geßler A., Kreuzwieser J., Simon J., Papen H. 2009. Nitrogen balance in forest soils: nutritional limitation of plants under climate change stresses. Plant Biol. 11:4-23.

Shi L., Guttenberger M., Kottke I., Hampp R. 2002. The effect of drought on mycorrhizas of beech (Fagus sylvatica L.): changes in community structure, and the content of carbohydrates and nitrogen storage bodies of the fungi. Mycorrhiza. 12:303-311.

Shokralla S., Spall J.L., Gibson J.F., Hajibabaei M. 2012. Next-generation sequencing technologies for environmental DNA research. Mol. Ecol. 21:1794-1805.

Simon J., Dannenmann M., Gasche R., Holst J., Mayer H., Papen H., Rennenberg H. 2011. Competition for nitrogen between adult European beech and its offspring is reduced by avoidance strategy. For. Ecol. Manag. 262:105-114.

Simon J., Waldhecker P., Brüggemann N., Rennenberg H. 2010. Competition for nitrogen sources between European beech (Fagus sylvatica) and sycamore maple (Acer pseudoplatanus) seedlings. Plant Biol. 12:453-458.

Stoelken G., Simon J., Ehlting B., Rennenberg H. 2010. The presence of amino acids affects inorganic $\mathrm{N}$ uptake in non-mycorrhizal seedlings of European beech (Fagus sylvatica). Tree Physiol. 30:1118-1128. 


\section{Abgrenzung der Beiträge der Autoren}

„Fagirhiza inflata“ + Fagus sylvatica L.

Descriptions of Ectomycorrhizae 13: 37 - 41 (2012)

Martin Leberecht ${ }^{1}$, Andrea Polle ${ }^{2}$, Reinhard Agerer ${ }^{2}$

${ }^{1}$ Erhebung und Auswertung der anatomischen/morphologischen Daten, Zeichnungen und Manuskript

${ }^{2}$ Korrektur des Manuskripts

Dissecting the contributions of local ectomycorrhizal assemblages and microbial communities on nitrogen uptake of European beech (Fagus sylvatica) (submitted to Applied and Environmental Microbiology)

Martin Leberecht ${ }^{1,2,3,4,11,12}$, Michael Dannenmann ${ }^{2,7,8}$, Silvia Gschwendtner ${ }^{2,5,6}$, Silvija Bilela $^{2,9,10}$, Rudolf Meier ${ }^{7,8}$, Judy Simon ${ }^{10}$, Heinz Rennenberg ${ }^{10}$, Michael Schloter ${ }^{6}$, Andrea Polle ${ }^{1,4,11,12}$

${ }^{1}$ Planung des Experiments

${ }^{2}$ Durchführung des Experiments

${ }^{3}$ Erhebung und ${ }^{4}$ Auswertung der Mykorrhiza- und Pflanzendaten

${ }^{5}$ Erhebung und ${ }^{6}$ Auswertung der Bakteriendaten

${ }^{7}$ Erhebung und ${ }^{8}$ Auswertung der Bodendaten

${ }^{9}$ Erhebung und ${ }^{10}$ Auswertung der Aminosäuredaten

${ }^{11}$ Zusammenführen der Daten und zusammenfassende Auswertung

${ }^{12}$ Manuskript (mit Beteiligung aller Autoren)

Climate change impairs nitrogen cycling in European beech forests (submitted to Nature Geoscience)

Michael Dannenmann ${ }^{1,2,7,8,12,13}$, Carolin Bimüller2,7,8, Silvia Gschwendtner ${ }^{2,5,6}$, Martin Leberecht ${ }^{2,3,4}$, Javier Tejedor ${ }^{8,12}$, Silvija Bilela ${ }^{2,9,10}$, Rainer Gasche ${ }^{2,7,8}$, Marc Hanewinkel ${ }^{11}$, Andri Baltensweiler ${ }^{11}$, Ingrid Kögel-Knabner ${ }^{1,8}$, Andrea Polle ${ }^{1,4}$, Michael Schloter ${ }^{1,6}$, Judy Simon ${ }^{1,10}$, Heinz Rennenberg ${ }^{1,10}$

${ }^{1}$ Planung des Experiments

${ }^{2}$ Durchführung des Experiments

${ }^{3}$ Erhebung und ${ }^{4}$ Auswertung der Mykorrhizadaten

${ }^{5}$ Erhebung und ${ }^{6}$ Auswertung der Bakteriendaten

${ }^{7}$ Erhebung und ${ }^{8}$ Auswertung der Bodendaten

${ }^{9}$ Erhebung und ${ }^{10}$ Auswertung der Pflanzendaten

${ }^{11}$ Modellierung und Verbreitungskarten

${ }^{12}$ Zusammenführen der Daten und zusammenfassende Auswertung

${ }^{13}$ Manuskript (mit Beteiligung aller Autoren) 


\section{Danksagung}

Zuerst möchte ich meiner Betreuerin Frau Prof. Dr. Andrea Polle danken, die mir das Thema zur Verfügung gestellt hat, mich in allen Belangen unterstützt hat. Ich danke Herrn Prof. Dr. Stefan Scheu, der sich bereiterklärt hat die Arbeit als Zweitgutachter zu beurteilen und Herrn Prof. Dr. Reiner Finkeldey für die Tätigkeit als dritter Prüfer.

Allen Kollegen aus der DFG Gruppe Buche danke ich für die hervorragende Zusammenarbeit im Feld und beim Schreiben der Paper: Dr. Michael Dannenmann und Javier Tejedor (IMK-IFU Garmisch-Partenkirchen, Karlsruhe Institut of Technology), Prof. Dr. Heinz Rennenberg, Dr. Judy Simon und Silvija Bilela (Professur für Baumphysiologie, Freiburg), Prof. Dr. Michael Schloter und Dr. Silvia Gschwendtner (Institut für Bodenökologie, Helmholtz Zentrum München), Prof. Dr. Ingrid Kögel-Knabner und Caroline Bimüller (Lehrstuhl für Bodenkunde, TU München).

Herrn Prof. Dr. Reinhard Agerer gilt besonderer Dank. Trotz seiner sehr begrenzten Zeit kurz vor dem Ruhestand hat er mir ermöglicht, drei Wochen lang in 1:1 Betreuung die Grundlagen des Morpho- und Anatomotypings aus erster Hand zu erlernen.

Meinen Zimmerkollegen Lara Danielsen, Dejuan Ning, Michaela Rath und Nan Yang danke ich für die sehr konstruktiven fachlichen und nichtfachlichen Gespräche und die über die gesamte Doktorandenzeit hervorragende Arbeitsatmosphäre.

Allen Mitarbeitern des Büsgen-Instituts, Abteilung Forstbotanik und Baumphysiologie sei ganz herzlich für die Mitarbeit an diversen Ernten, Labor- und Gewächshausarbeiten und die fachliche Unterstützung gedankt. Besonders möchte ich Thomas Klein danken, der mich immer wieder auf Dienstreisen begleitet hat, unter widrigen Umständen in Tuttlingen im Feld bei bester Laune bis zu 20 Stunden am Tag gearbeitet hat, und mich im Labor tatkräftig unterstützt hat.

Dank gilt auch Herrn Dr. Jens Dyckmans und seinen Mitarbeitern vom Kompetenzzentrum für stabile Isotope (KOSI) der Universität Göttingen für die schnelle und präzise Durchführung der Messungen und die fachliche Beratung.

Für die finanzielle Förderung danke ich der Deutschen Forschungsgemeinschaft (DFG, Po 361/19-1).

Zu guter Letzt möchte ich meinen Eltern und meiner Freundin danken. Ohne ihre Unterstützung, vor allem in moralischen Belangen, wäre es nicht möglich gewesen, diese Arbeit zu beenden. 


\section{Lebenslauf}

Persönliche Daten

Name:

Martin Leberecht

Anschrift:

Am Brachfelde 2a

37077 Göttingen

Geboren am:

Familienstand:

17.09.1982 in Hamburg

ledig

Staatsangehörigkeit: deutsch

Berufstätigkeit

06/10-02/14 Doktorand am Büsgen-Institut, Abt. Forstbotanik und Baumphysiologie, Georg-August-Universität Göttingen

06/10-06/13 Wissenschaftlicher Mitarbeiter am Büsgen-Institut, Abt. Forstbotanik und Baumphysiologie, Georg-August-Universität Göttingen

09/08-06/10 Büroleiter und stellv. Geschäftsführer der Münchner Baumkletterschule

04/08-08/08 Arbeitsvorbereiter bei der Ernst Fischer GmbH + Co.KG (Produzent von Elektro-Labormöbeln), Freudenstadt

Studium

2005-2008 Master-Studium der Forstwissenschaften und Waldökologie an der Georg-

August-Universität Göttingen, Schwerpunkt „Holzbiologie und

Holztechnologie“,

2002-2005 Bachelor-Studium der Forstwissenschaften und Waldökologie an der GeorgAugust-Universität Göttingen

$\underline{\text { Schulbildung }}$

1995-2002 Gymnasium am Kattenberge, Buchholz i.d. Nordheide

1993-1995 Orientierungsstufe am Kattenberge, Buchholz i.d. Nordheide

1989-1993 Grundschule Holm-Seppensen 